الثرط الجعلي دراسة أصولية وأثره في الفروع الفقهية في باب الإجارة

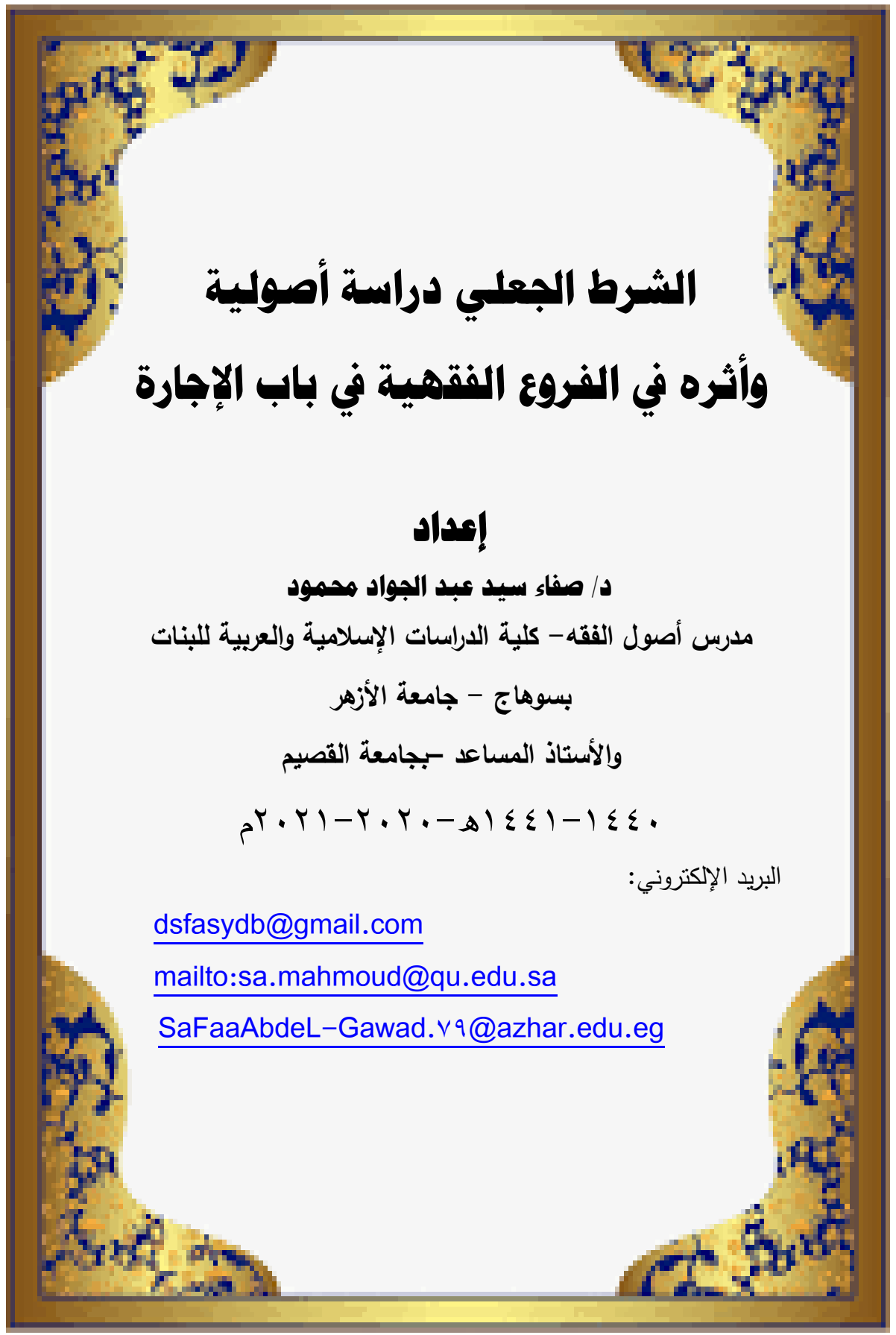


الثرط الجعلي دراسة أصولية وأثره في الفروع الفقهية في باب الإجارة

FVA مجلة كلية الداسات الإسلامية والعربية للبنات بسوهاج - العدد السادس والعشرون ديسمبر ·.r. 


\section{بسم الله الرحمز الرهيم

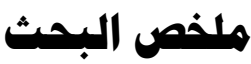

يحتوي هذا البحث على دراسة أصولية مقارنة وتطبيقية حول موضوع

الثروط الجعلية وبعض التطبيقات المعاصرة على باب الإجارة، وقد تتاولت فيه

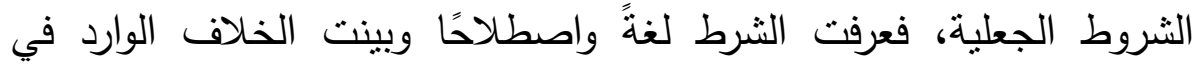
تعريف الثرط وقلت إن الخلاف لفظي ولا أثر له في الفروع الفقهية، ثم عرفت

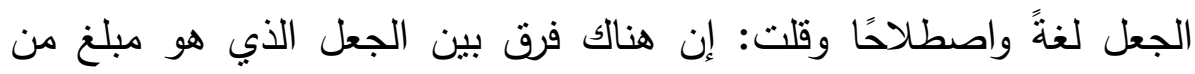

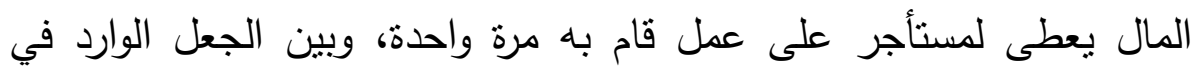
الشروط الجعلية وهو وضع بعض الثروط في العقد من قبل أحد الطرفين .

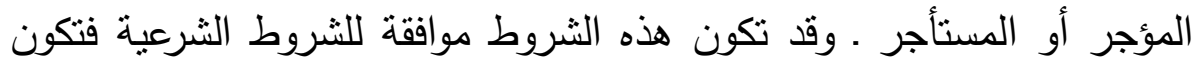

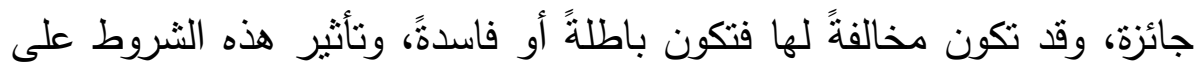
العقد هل هي مبطلةٌ له أم لا؟ وأقوال العلماء في ذلك. لكان. وقلت إن: الجمهور والحنفية متفقون على أن الثرط لا لأنثر له في أله في الحكم

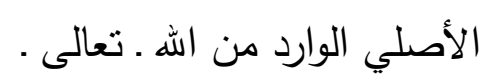

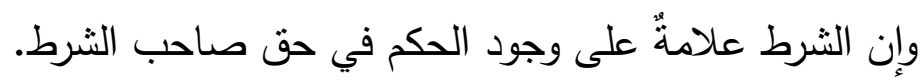

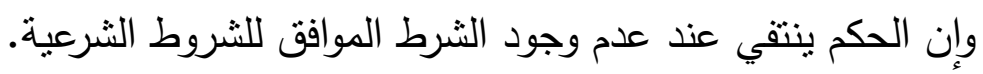
وإن الثروط الجعلية قسمها الجمهور إلى أربعة أقسام وذللك باعتبار مصدره: وهي: شرعيٌ، ووضعيّ، وعاديّ برجع للعرف والعادة، ومنها ما هو لغويٌ.

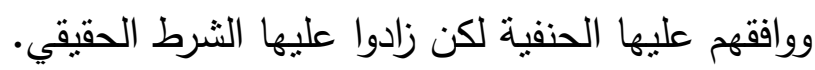

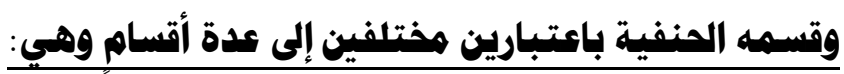

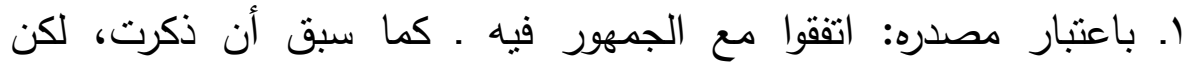
زادوا الحقيقي. 
ז. باعتبار وجود حكم له إلى خمسة أقساحٍ: محضٌ، وله حكم العلل، وله حكم السبب، وشرط اسم لا حكم وهو مجاز ، وشرط بمعنى العلامة.

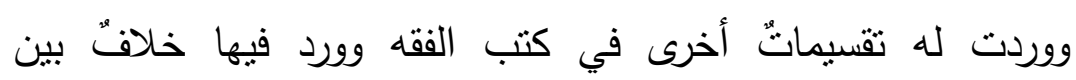
الجمهور والحنفية وهي: تقسيم الثرط إلى صحيحٍ وباطلٍ أو فاسدٍ . فهما بمعنى واحدٍ عند الجمهور ـ وفرق الحنفية بين الباطل والفاسد بأن الباطل ما كان مبطلًً للعقد، أما الفاسد فهو ما كان الثرط فيه باطلً والعقد صحيحُّ.

* $\quad * \quad * \quad * \quad * \quad * \quad *$ 


\section{Research Summary}

This research contains a comparative and applied study on the subject of the conditions of making and some contemporary applications on the door of ijara, in which it dealt with the conditions of the making, $i$ knew the condition language and terminology and showed the disagreement contained in the definition of the condition and I said that the disagreement is verbal and has no effect in the doctrinal branches, then I knew the making language and terminology and I said: there is a difference between making money which is a sum of money given to a tenant for a work he did once, and the making contained in the making which is some of the conditions in the contract. Before one of the parties leased or rented and these conditions may be in accordance with the legitimate conditions and be a prize, and may be a violation of them, which may be invalid or corrupt, and the effect of these conditions on the contract is null or void? And the scholars say that.

I said that: The public and the Hanafi agree that the condition has no effect on the original ruling contained by Allah Almighty .

The condition is a sign of the existence of the provision against the holder of the condition.

The provision is not in the absence of a condition that agrees with the legal requirements. 


$$
\text { الثرط الجعلي دراسة أصولية وأثره في الفروع الفقهية في باب الإجارة }
$$

The conditions of the making are divided by the public into four sections, considering its source:

They are: legit, my situation, and normal ity due to custom and custom, some of which are linguistic. The tap agreed to them, but they increased the real requirement.

The tap divided it into several different sections:

1-Considering its source: They agreed with the public in it as I mentioned earlier, but They increased the real.

$r$-Considering that there is a ruling in five sections: pure, and he has the ruling of ills, and he has the ruling on reason, the condition of a name that is not a provision and it is a metaphor, and a condition in the sense of the mark.

There are other divisions in the books of jurisprudence, and there is a disagreement between the public and hanafi: the division of the condition into true, false or corrupt, which is in the same sense of the public and the difference between falsehood and corruption, that falsehood was not null and void, but the corrupt is what the condition is invalid and the contract is valid. 


\section{همة مـندة}

الحمد لله الذي جعل في كل زمان طائفةً من أهل العلم، يدعون من

ضل إلى الهدى وينهون عن الردى، يحيون للناس دينهم، ويجددون الإيمان في قلوبهم، فما أحسن آثارهم على الناس، ينفون عن دين الله تحريف الغالين وانتحال المبطلين وتأويل الضالين، الذين عقدوا ألوية البدع وأطلقوا عنان الفنتة مخالفين في الكتاب يقولون على الله وفي الله ـ تعالى اله عما يقول الظالمون علوا كبيرا. ما لا يعلمون، فنعوذ باله من كل فنتةٍ مضلةٍ وصلى الله على محمد لهد النبي وآله وسلم تسليمًا كثيرًا.

وبعد

\section{أولاً: أهـهية الموضوع:}

فإن الثروط الجعلية من الأمور الهامة التي يحتاج إليها الناس في كل

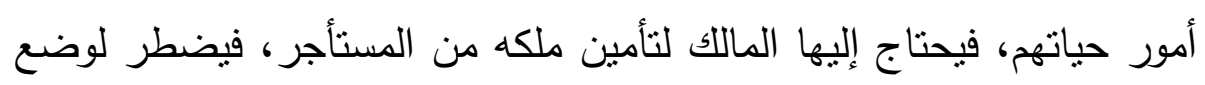
بعض القيود والثروط ليضمن بها حقه، وهذه الشروط قد تكون مواققة للشروط الشرعية فتكون صحيحة وقد تكون مخالفة لها فتكون باطلة ولا يصح العقد معها، لذلك فقد وضع العلماء بعض الضوابط لهذه الثروط تضمن حق كل من الطرفين.

لكن لم يكن موقف الفقهاء من تصحيح الثروط ومدى تأثثر الثروط الباطلة على العقود واحدًا، بل اختلفت مذاهبهم في ذلك تبعًا لأسباب موضوعية تتعلق بما ورد من نصوص في الغرر والثروط، وأسباب ذاتية تتعلق بفهم كل

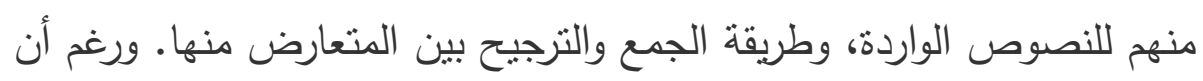
كل مذهب من المذاهب الققهية له طابعه الخاص وتقفيمه الموضوعي للشروط، إلا أن هنالك ملامح مشتركة تجمع بعض المذاهب حول مدى توسعها

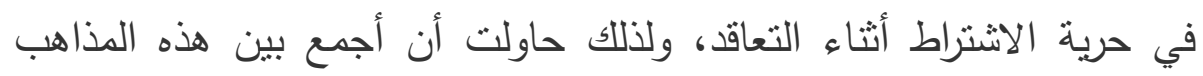
وأوفق بينها قدر المستطاع لأبين ما كان الخلاف فيها جوهريٌّ له أثز في 


\section{الثرط الجعلي دراسة أصولية وأثره في الفروع الفقهية في باب الإجارة}

الفروع وما كان فيها الخلاف لفظيٌ لا أثر له في الفروع، ثم أردفته بجانب تطبيقي على بعض الثروط الجعلية المعاصرة مع بيان الحكم الثرعي فيها مصحوبًا بالدليل وأقوال العلماء سواء القدامى أو المحدثين أو لجان الفتوى بـى بـى

\section{المعاصرين.

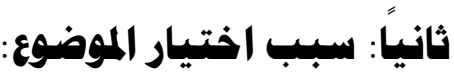

والذي دعانى إلى اختيار الموضوع عدة أسباب أوجزها فيما يلى: الئي:

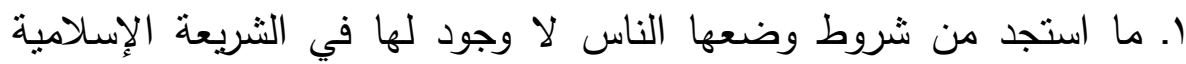

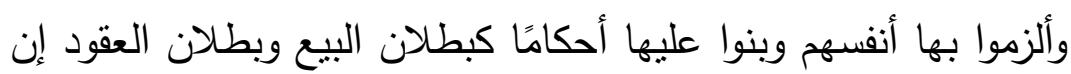
لم تتحقق. r. إيضاح ما هو موافق لما جاءت به الثربعة الإسلامية من هذه الثروط وما هو مخالف لها وبيان وجه بطلانه. r. عرض أهم المسائل المعاصرة واشتملت على بعض وبله هذه الثروط وبيان الموافق منها للشريعة الإسلامية والمخالف ورأي العلماء فيه. ع. محاولة إثراء المكتبة الأصولية بما هو جديدٌ ومفيدٌ بإذن الله.

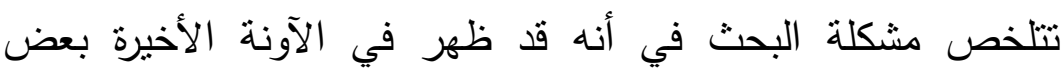
الثروط التي وضعها الناس في عقودهم لم تكن في كتاب الله ولا في سنة

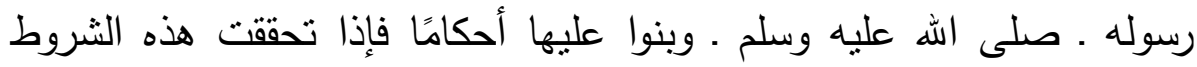
صححوا عقودهم وإذا لم تتحقق أبطلوا عقودهم، فكان من الجدير بالبحث نتاول هذه الموضوعات وبيان الحكم الشرعي لهذه الشروط، وأيضًا بيان ما كان منها

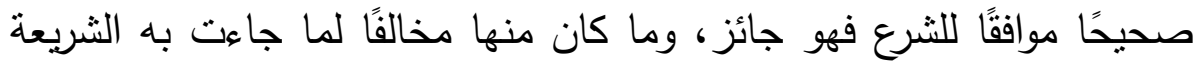
فيكون باطلًا، حتى يكون الناس على بينةٍ من أمرهم، ولا ييتدعوا في الدين ما فانِ

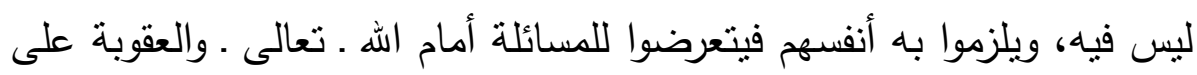
ما خالفوا فيه أوامر الله . عز وجل .، وأقوال نبيهم . صلى الله عليه وسلم . . 


\section{رابهًا: الدراسات السابقة للموضوع:}

ا. نظرية الثروط المقترنة بالعقد في الشربعة والقانون د/ زكي الدين شعبان. وهذه الدراسة تختلف عن موضوع بحثي من حيث إنها تدرس نظرية

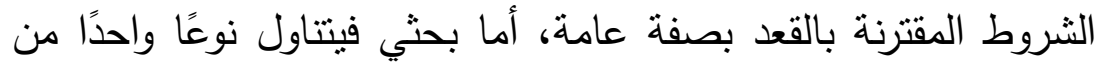

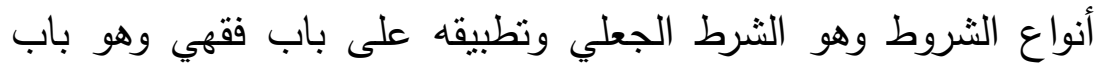
الإجارة؛ لكثرة وقوع هذا النوع من أنواع الثرط فيه هذا الباب، مما يؤدي

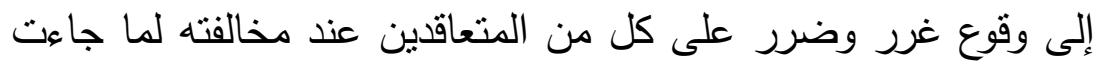
به الثريعة الإسلامية.

r. نظربة الثرط الجزائي بين الفقه والقانون د/ جواد محمود أحمد بحر. وهذه الدراسة تختلف عن موضوع بحثي من حيث إنها تدرس نوعًا

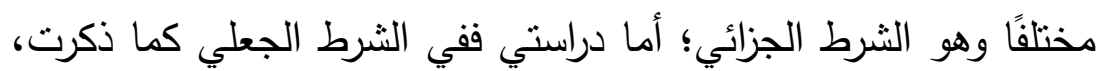
وأيضًا تختلف عنها في الجانب التطبيقي وهو باب الإجارة. r. الثروط الجعلية المتعلقة بالتقاضي د/ تركي بن عبد العزيز الجنيدل.

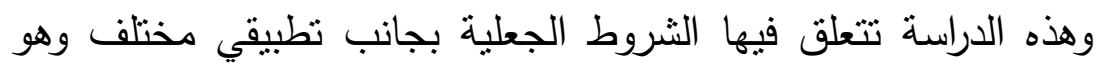
باب التقاضي، أما بحثي ففي باب الإجارة، وأيضًا من حيث المنهج فدراستي استقرائية مقارنة وتطبيقية، أما هذه الدراسة فتدرس الثروط الجعلية بصفة عامة دون مقارنة بين المذاهب. ع. الثرط الجعلي حكمه وأثزه في عقد الزواج دم/ خالد محمد صالح. وهذه الدراسة تختلف عن بحثي في الجانب التطبيقي أيضًا حيث يتم التطبيق فيها على عقد الزواج، أما بحني فعلى باب الإجارة، وأيضًا المنهج الاستقرائي المقارن. وقد جعلته بعنوان: (الثرط الجعلي دراسة أصولية وتطبيقه على الفروع الفقهية في باب الإجارة). 


\section{خامساً: المنهج التفصيلي للبحث:}

ا. ما يخص هذه الدراسة دن حيث إنها استقرائيةٌ بمعنى أنني سأنتبع فيها الأقوال والنصوص من مصادرها الأصلية قدر المستطاع، ثم أقارن بين

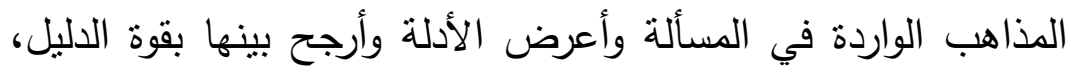
وأبني على الراجح المسائل التي نم اختيارها في الجانب التطبيقي. r. عزوت الآيات بذكر اسم السورة ورقم الآية. r. خرجت الأحاديث من مصدرها، مع الحكم عليها إذا كانت من غير

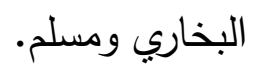

ع. ترجمت للأعلام من مصادرها الأصلية. 0. نسبت كل قول لصاحبه قدر المسنطاع، فإن وجدت أقوال مذكورة في دهن المصادر بدون ذكر قائلها ولها صلة بموضوع البحث وحاجة البحث داعية لذكرها ذكرتها وعزوتها للكتاب الذي وردت فيه ونه

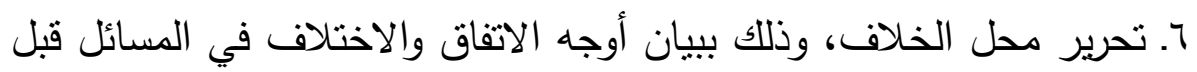
عرض المذاهب والأقوال الواردة فيها. وهذا جهد المقل وعمل بشريٌّ، لا يخلو من خطأ، ولكن حسبي أني قصدت به وجه الله أولًا وأخيراً، ثم المشاركة في نشر العلم والبحث عن الأحكام التي يحتاج إليها الناس في أمور دينهم ودنياهم.

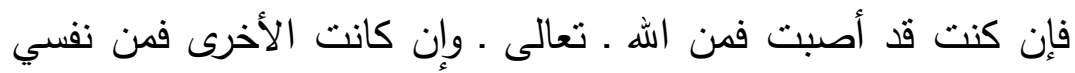

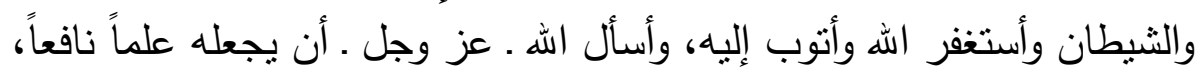
وعملاً صالحاً متقبلاً، وأن يرزقنا الإخلاص في في القول والعمل. إنه ولي ذلك . للك والقادر عليه. وصل اللهم على سيدنا محمد وعلى آله وصحبه وسلم، والحمد لله

$$
\text { أولاً وآخراً. }
$$

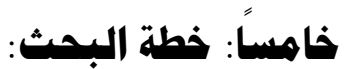

هذا البحث يتضمن: مقدمةً وثلاثة مباحثٍ وخاتمة وفهرسًا للمراجع،

$$
\text { وآخر للموضوعات. }
$$




\section{أولا الاقدهمة: وتتضمن:}

ا. أهمية الموضوع. r. سبب اختياره. r. الدراسات السابقة للموضوع. ع ـ المنهج التفصيلي للبحث. 0ـ خطة البحث. المبحث الأول: تعريف (الثرط ـ الجعل ـ الإجارة) واختلاف العلماء فيها. وبتضمن أربعة مطالب: الاطلب الأول: تعريف الثرط لغةً واصطلاحًا عند الحنفية والجمهور . وبتضنمن ثلاث مسائل: المسألة الأولى: تعريف الثرط لغةًة. المسألة الثانية: تعريف الثرط اصطلاحًا عند الحنفية. المسألة الثالثة: تعريف الثرط اصطلاحًا عند الجمهور . الاطلب الثاني: تعريف الجعل لغةً واصطلاحًا. وفيه ثنلاث مسائل: المسألة الأولى: تعريف الجَعل لغةً. المسألة الثانية: تعريف الجَعل اصطلاحًا. المسألة الثالثة: تعريف الشرط الجعلي اصطلاحًا. الاطلب الثالث: أدوات الثرط واختلاف العلماء فيها. وفيه ثلاث مسائل: المسألة الأولى: أدوات الثرط. المسألة الثانية: أقسام أدوات الثرط. الثوات الثنرط. المسألة الثالثة: الخلاف الوارد في أدوات الثرط. الاطلب الرابع: تعريف الإجارة لغةً واصطلاحًا. وفيه مسألتان: 


\section{المسألة الأولى: تعريف الإجارة لغةً. \\ المسألة الثانية: تعريف الإجارة اصطلاحًا. \\ الاطلب الخاهس : مشروعية الثرط الجعلي.}

المبحث الثاني: أقسام الثرط عند الحنفية والجمهور • ويتضمن ثناثة مطالب:

الاملب الأول: أقسام الثرط عند الحنفية.

الالملب الثاني: أقسام الثرط عند الجمهور •

الاملب الثالث: أنواع وأقسام الشروط الجعلية عند كل من الحنفية

$$
\text { والجمهور }
$$

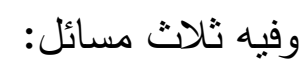

المسألة الأولى: أنواع الثروط الجعلية.

المسألة الثانية: أقسام الثروط الجعلية من حيث اعتبارها شرعًا وعدم

$$
\text { اعتبارها. }
$$

المسألة الثالثة: أقسام الثروط الجعلية باعتبار أثرها على التصرفات

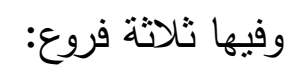

الفرع الأول: الثرط الصحيح.

الفرع الثاني: الثرط الباطل.

الفرع الثالث: الثرط الفاسد.

المبحث الثالث: أمتلة تطبيقية معاصرة للشروط الجعلية على باب الإجارة.

ويتضمن خمسة مطالب:

الإطلب الأول: الإيجار المنتهي بالتمليك.

الاملب الثاني: شرط دفع مقدم للإيجار •

الامطلب الثالث: الشرط الجزائي في عقود الإيجار . 
الشرط الجعلي دراسة أصولية وأثره في الفروع الفقهية في باب الإجارة

$$
\begin{aligned}
& \text { الاطلب الرابع: الإيجار المؤبد المعروف بالإيجار القديم. } \\
& \text { المطلب الخامس : حكم اشتراط صيانة العين المؤجرة. } \\
& \text { الخاتمة وتتضمن: }
\end{aligned}
$$

أهم النتائج التي توصلت إلبها من خلال البحث. وأهم التوصيات التي

أوصي بها نفسي أولًا والباحثين من بعدي ثانيًا.

* $\quad * \quad * \quad * \quad * \quad * \quad *$




\section{المبحث الأول}

تعريف (الشرط ـ البعل ـ الإجارة) واختلاف العلمهاء فيها.

\section{الإطباب الأول}

\section{تعريف الشرط لغةً، واصطلاحًا عند الهنفية والبمهور}

$$
\text { ويتضمن ثلاث مسائل: }
$$

المسألة الأولى: تعريف الثرط لغةً.

المسألة الثانية: تعريف الثرط اصطلاحًا عند الحنفية.

المسألة الثالثة: تعربف الثرط اصطلاحًا عند الجمهور . لمريف

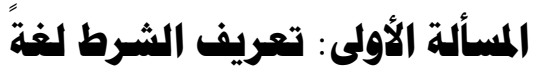

وردت مادة (شَرَطًا) في اللغة بعدة معاني منها ما كان بسكون الراء

ومنها ما كان بفتحها:

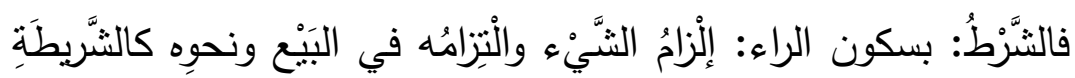

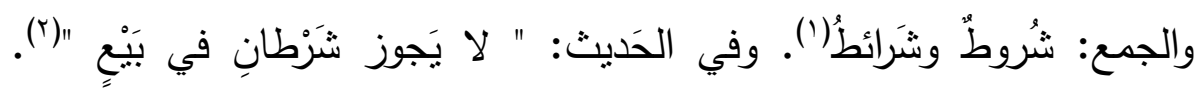
والثَرَطَ: بالتَّحريكِ له عدة معان منها:

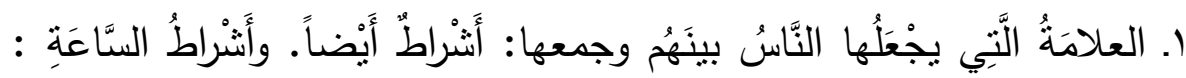

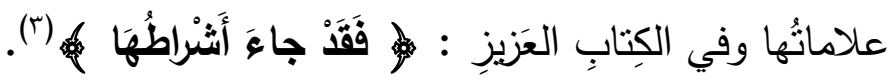

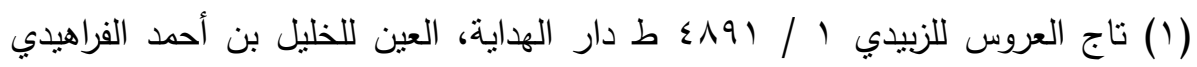

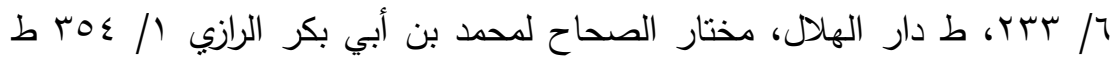

$$
\text { مكتبة لبنان. }
$$

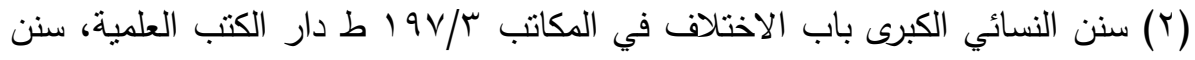

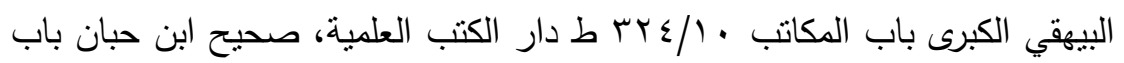

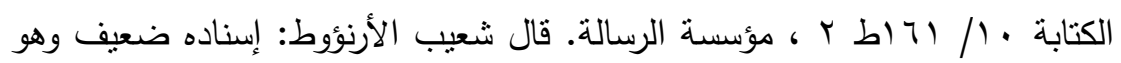

$$
\begin{aligned}
& \text { حديث صحيح. } \\
& \text { (r) سورة محمد آية ( } 1 \text { ( ) . }
\end{aligned}
$$




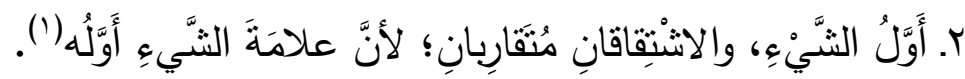

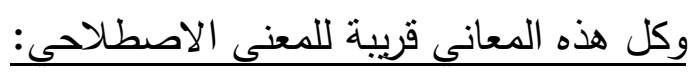

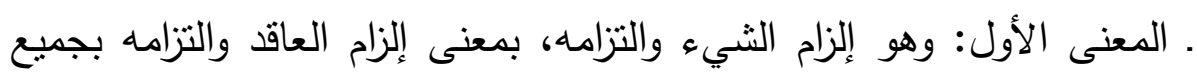
شروط العقد سواء وضعها الثارع أو العاقد. ـ والعلامة؛ لأنه يقصد بشروط العقد: العلامات التي وضعها الثارع أو العاقد للعقد ليميزه عن غيره من العقود. . وأول الثيء؛ لأن الثرط لابد وأن يكون في بداية العقد.

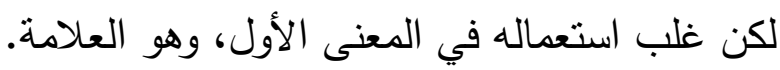

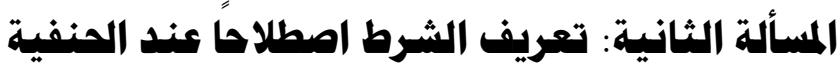

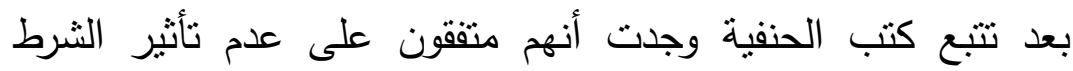

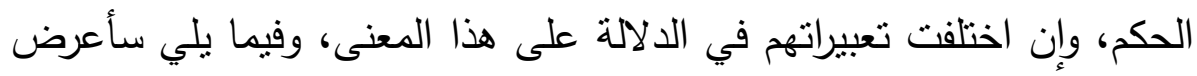
بعضًا مما ورد في كتب الفقهاء ثم أستخلص المعنى المتفق عليه بينهم.

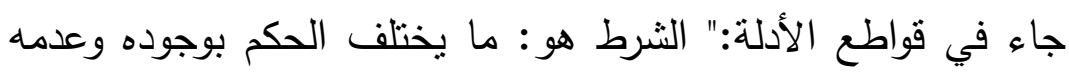

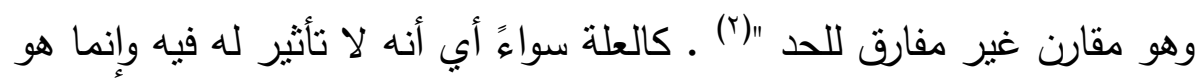
علامة على الحكم من غير نأثير أصلًا. وجاء في أصول السرخسي:" اسم لما يضاف الحكم إليه وجودًا عنده

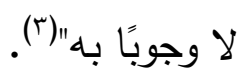

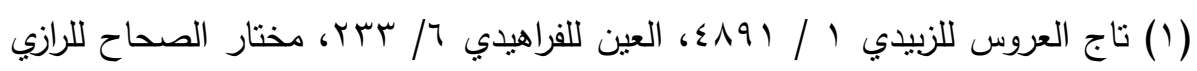
(

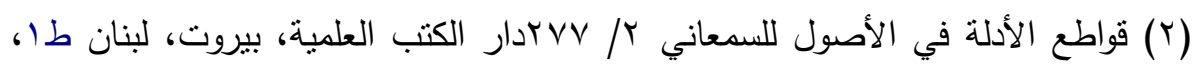

$$
\begin{aligned}
& \text {. }
\end{aligned}
$$

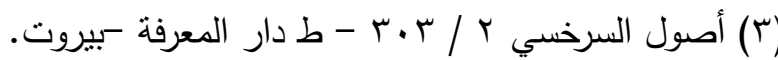


مثال ذلك: إن قول القائل لامرأته إن دخلت الدار فأنت طالق، يجعل

دخول الدار شرطاً حتى لا يقع الطلاق بهذا اللفظ إلا عند الدخول"(().

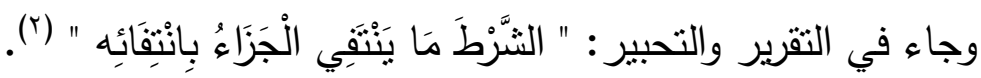

وبالنظر في التعريفات السابقة أرى أنهم هتفقون على بعض الأهور هذها:

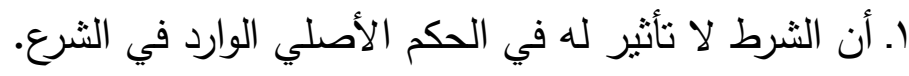
r. أن الثرط علامة على وجود الحكم في حق صاحب الثرط. r. أن الحكم ينتفي عند عدم وجود الثرط في حق صاحب الثرط.

\section{المسألة الثالثة : تعريف الشرط اصطلاحًا عند الجمهور}

بالنظر في تعريفات المتكلمين اتضح لي أنهم متفقون مع الحنفية في

$$
\text { المعنى وإن اختلفت عباراتهم. }
$$

وفيما يلي سأعرض بعض ما ورد عنهم من تعريفات، ثم أرجح بينها

وأذكر أسباب الترجيح، وأتناول الراجح بالثرح والبيان.

جاء في المحصول:" الثرط هو الذي يقف عليه المؤثر في تأثيره

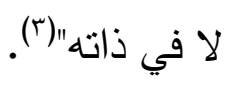

(1) كثف الأسرار شرح أصول البزدوي / / 197 - ط دار الكتاب الإسلامي.

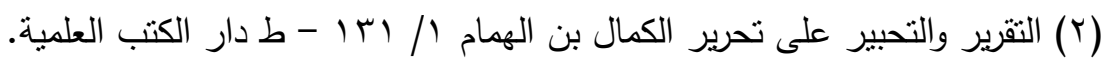

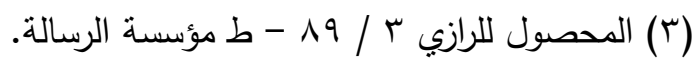




\section{وإلى ذلك ذهب الزركثي (')، والبيضاوي(؟).}

وجاء في الإحكام للآمدي أنه: " ما بلزم من نفيه نفي أمر ما على وجه

لا يكون سببًا لوجوده ولا داخلًا في السبب" (؟).

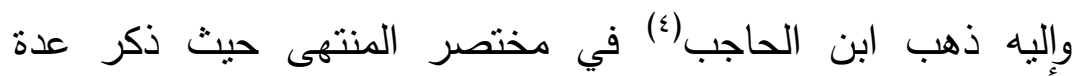

تعريفات والاعتراضات الواردة عليها، ثم عقبها بذكر الراجح عنده.

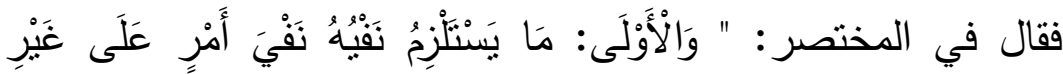

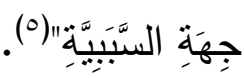

(1) هو : الإمام بدر الدين محمد بن بهادر بن عبد الله الزركثي، عالم بفقه الثافعية

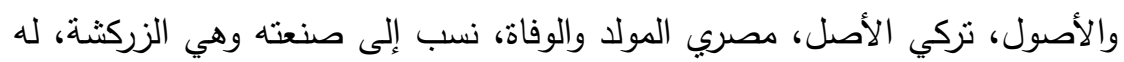

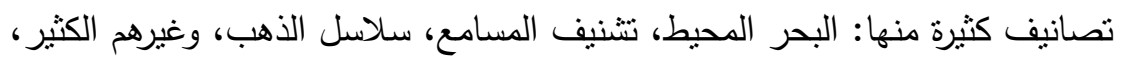

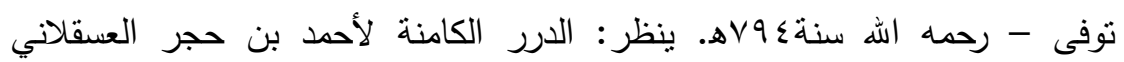

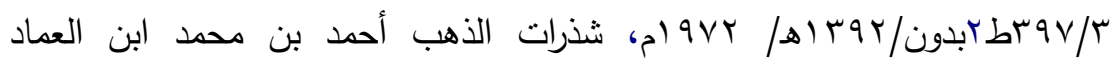

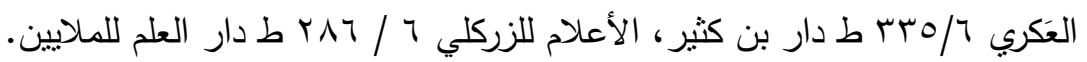

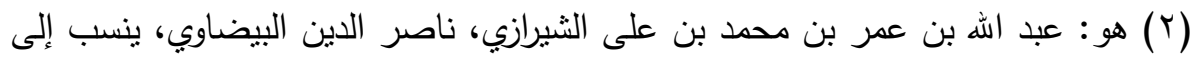

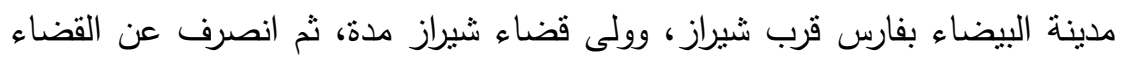

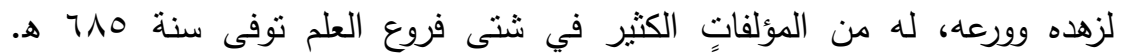

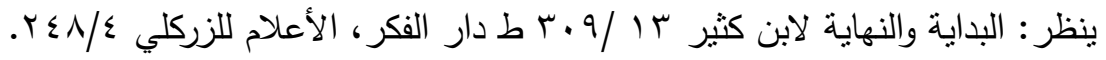

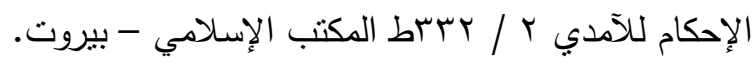

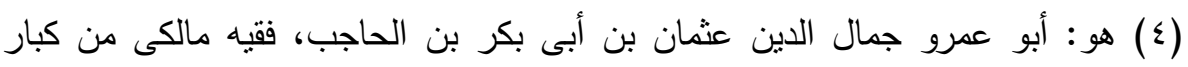

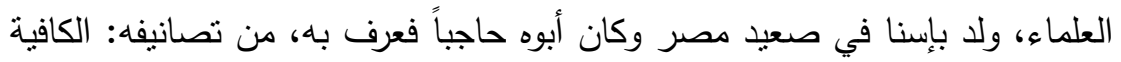

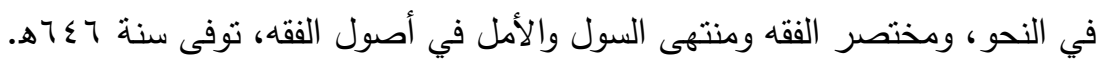

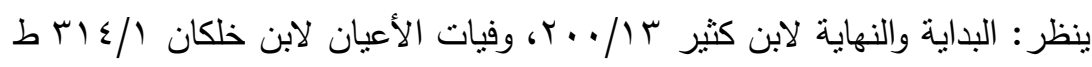

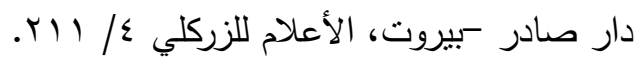

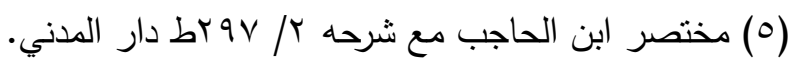


وذهب إلبه الطوفي(') في مختصر الروضة مع اختلاف في

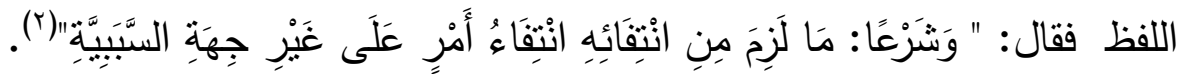

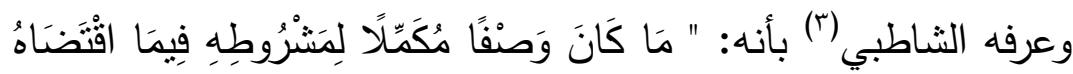

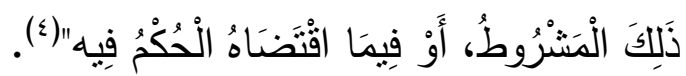
وعرفه القرافي (0) في أنوار البروق بقوله: " الثََّّْطُ مَا يَلَْزَجُ مِنْ عَدَمِهِ

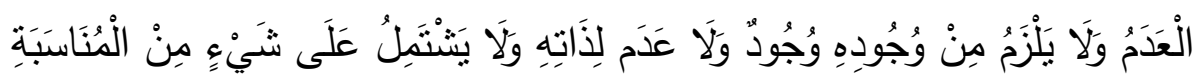
فِي ذَاتِهِ بَلْ فِي غَيْرِهِ "(َ).

(1) هو : سليمان بن عبد القوى بن عبد الكريم، نجم الدين الطوفي الحنبلي، الفقيه الأصولي،

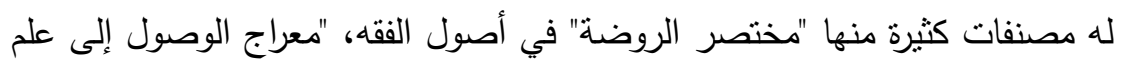

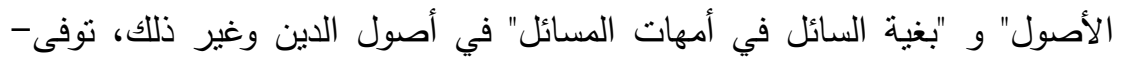

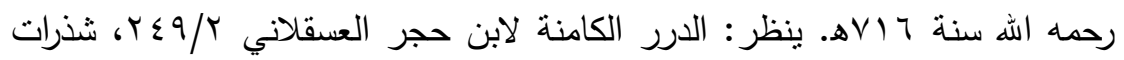

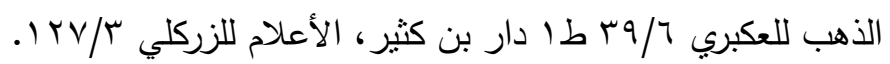

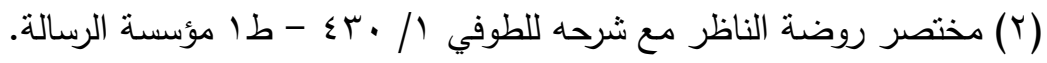
(T) هو: إبراهيم بن موسى بن محمد اللخمي الغرناطي الثهير بالثاطبي، المفسر الفقيه

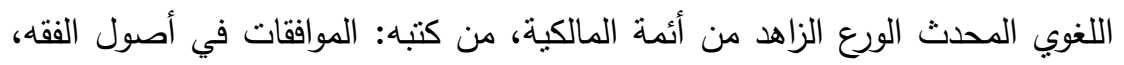

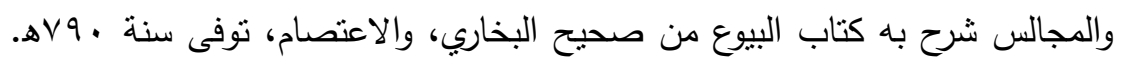

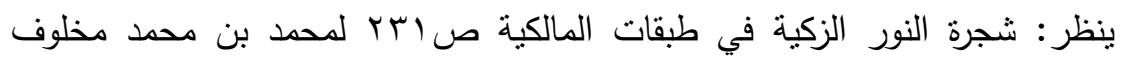

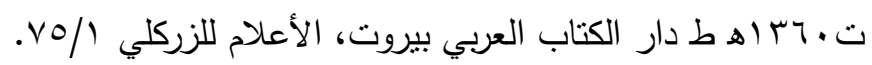

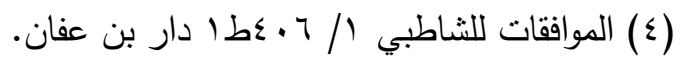

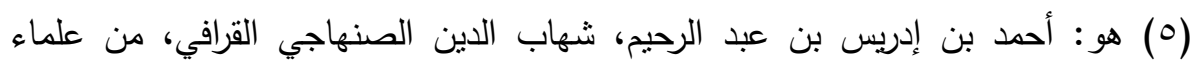

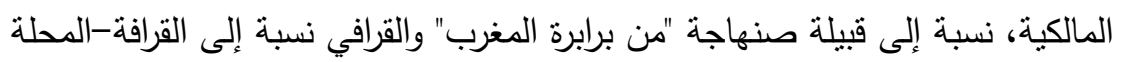

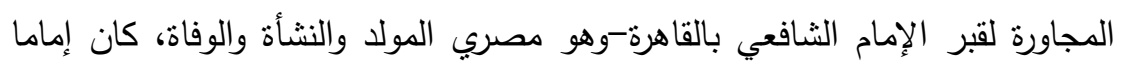

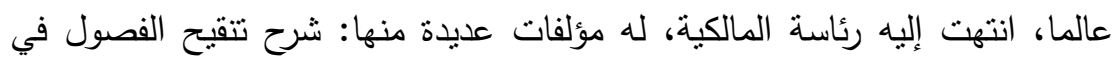

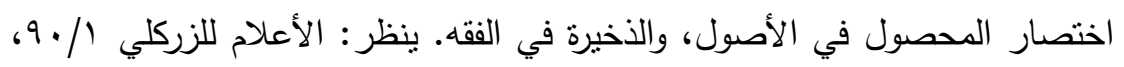

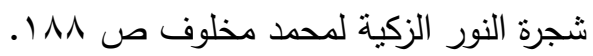

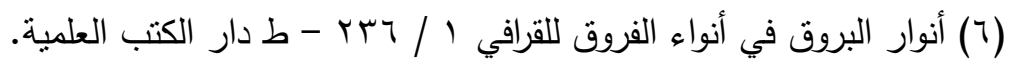


وكل هذه التعريفات السابقة ورت عليها اعتراضات وردود كثيرة

$$
\text { لاعي داعي لذكرها هنا. }
$$

والذي مال إليه أكثر العلماء ورجحوه هو تعريف القرافي، وإن كان هذا

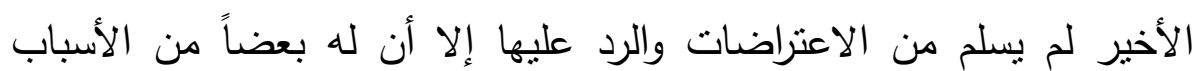
جعلته أقوى هذه التعريفات منها:

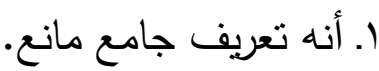
r. وأن ما سبقه من تعريفات عليها ملاحظات قوية تجعلها لا تقوى ولا تتهض للترجيح. r. أن هذا التعريف رجحه كثير من العلماء.

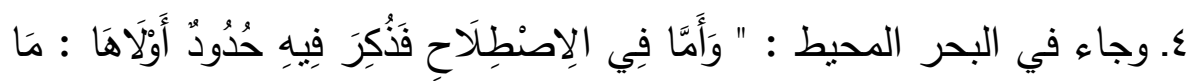

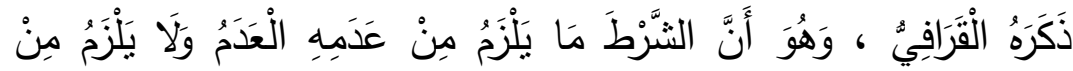

$$
\text { وُجُودِهِ وُجُودُ وَلَا عَدَمَ لِذَاتِهَ " ('). }
$$

وأنا أتتفق معهم في الرأي، لقوة أدلتهم وقلة الاعتراضات الواردة عليها. وفيما يلي إخراج لبعض محترزات التعريف:

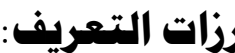

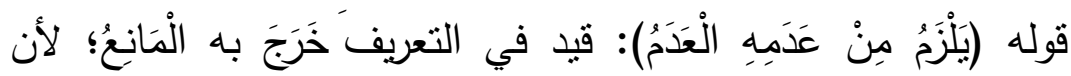
المانع لَا بَلْزَمُ مِنْ عَدَمِهِ شَتْهُهُ.

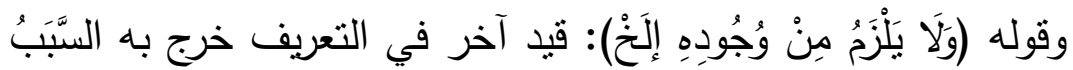
إذْ بَلْزَمُ مِنْ وُجُودِ السبب وُجُودُ الحكم.

(1) البحر المحيط للزركثي \& / $10 \mathrm{~V}$ - ط دار الكتبي. 


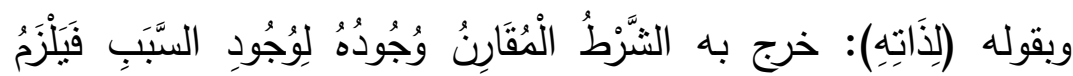

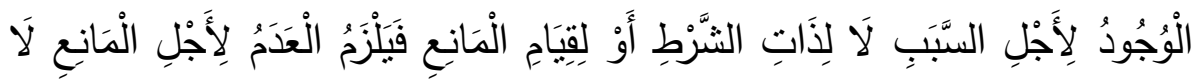
لِذَاتِ الثنَّرْط.

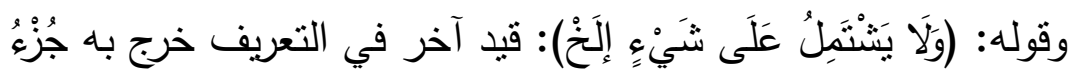

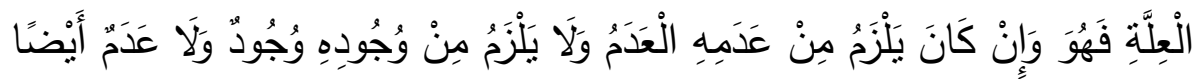

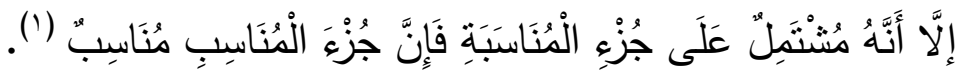

* $\quad * \quad * \quad * \quad * \quad *$

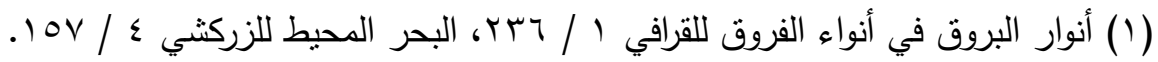




\section{الاملب الثاني}

تمريف الجمل لغة واصطلاهًا

وفيه ثلاث مسائل:

المسألة الأولى: تعريف الجَعل لغة.

المسألة الثانية: تعريف الجَعل اصطلاعًا.

المسألة الثالثة: تعريف الشرط الجعلي اصطلاحًا.

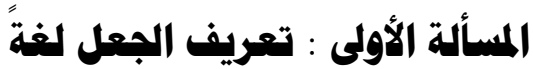

تأتيى مادة جَعَلَ في اللغة بعدة معان منها:

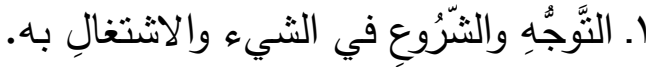

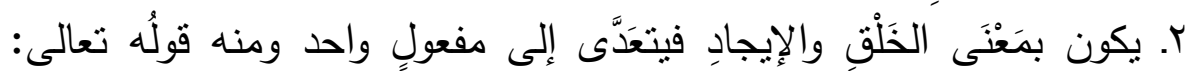

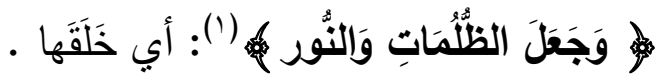

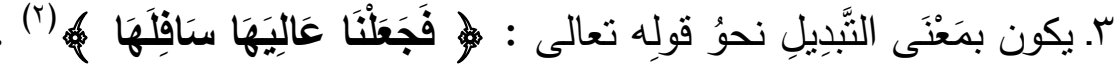

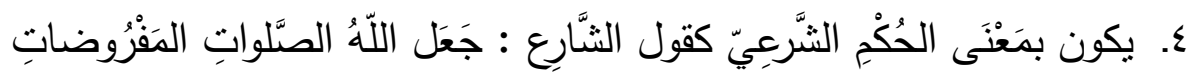

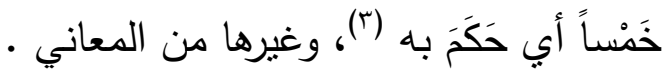

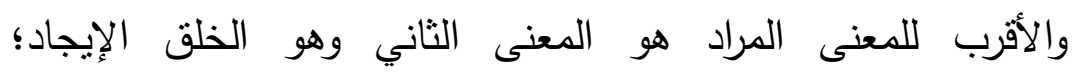
لأن الثرط الجعلي لم يكن موجودًا ضمن الثروط الشرعية لكن أوجده

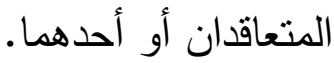

جاء في لسان العرب : "والجُعْل والجِعال والجَعِيلة والجُعالة والجِعالة

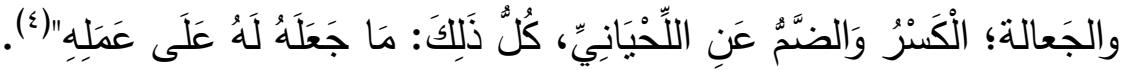

$$
\begin{aligned}
& \text { (1) سورة الأنعام ( الآية 1) • }
\end{aligned}
$$

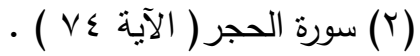

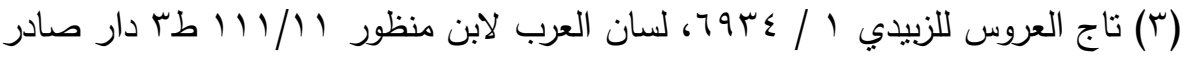

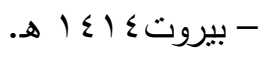

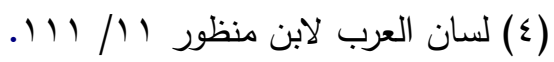




\section{المسألة الثانية : تعريف الجعل اصطلاحًا}

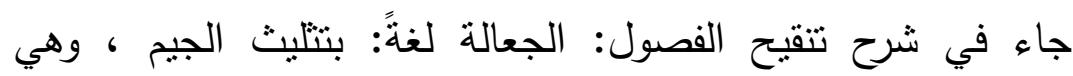

ما جُعل للإنسان من شيءٍ على فعلٍ ما (')

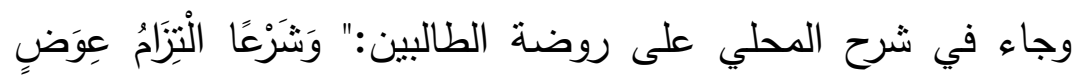

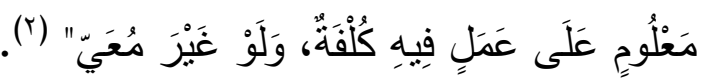

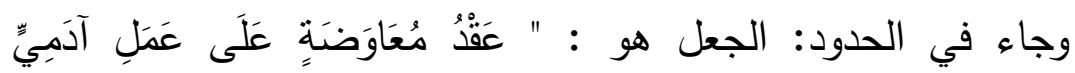

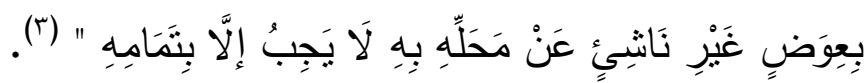

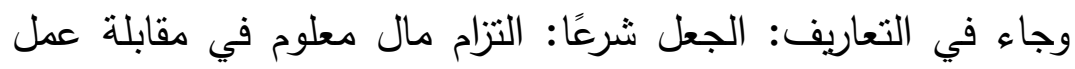

معلوم لا على وجه الإجازة (؛). ومن خلال هذه التعريفات ألاحظ أن الجعل بفتح الجيم وضمها لإنها

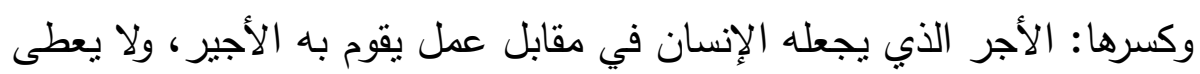
هذا الجعل إلا بعد الانتهاء من العمل المطلوب منه.

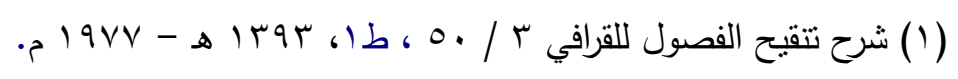

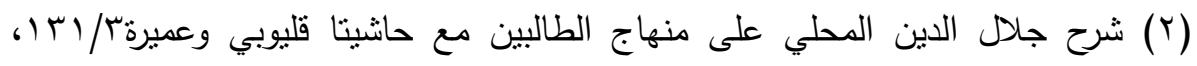

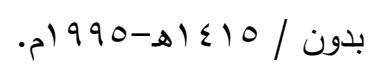

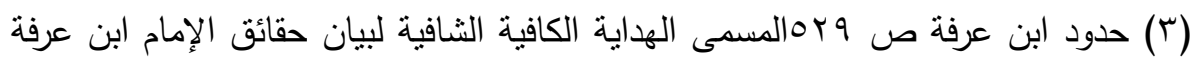

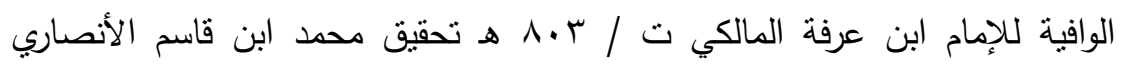

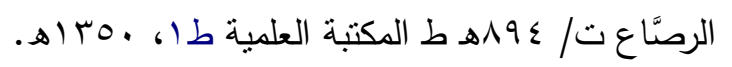

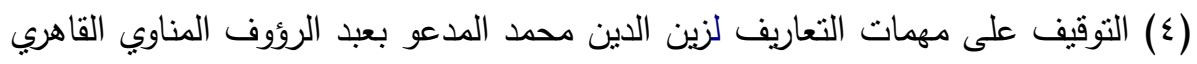

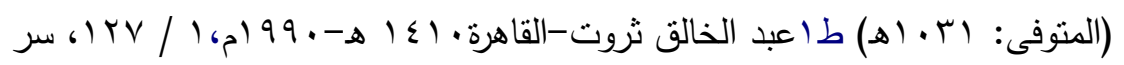

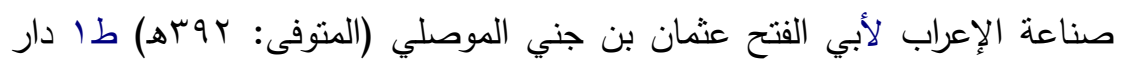

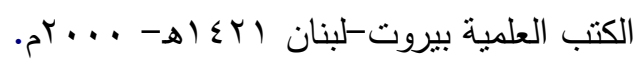


وألاحظ كذلك الفرق بينه وبين الأجير: أن الأجير يعطى الأجر على

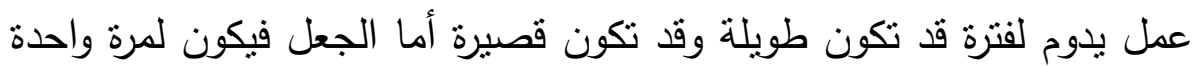

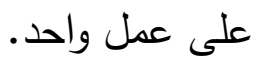

\section{وهناك فرق بين الجعالة والإجارة:}

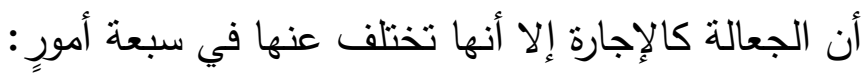

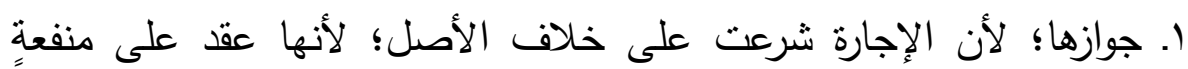

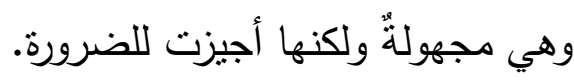

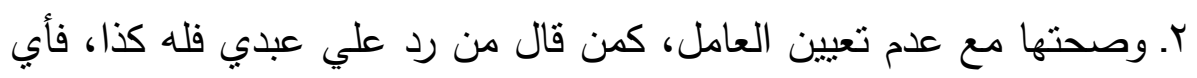
إنسان يقوم بهذا العمل بستحق هذا الجعل.

r. جوازها وصحتها على عملٍ مجهولٍ، إذا تعسر ضبطه كرد الآبق، وإلا فلا لهان

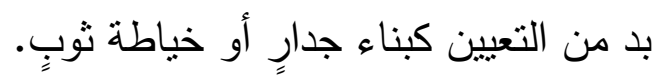

r. توقف استحقاق العوض على الفراغ من العمل. وهذه الفروق متفقّ عليها. وهناك أثياء محل خلافٍ لكن الراجح فيها أنها غير معتبرةٍ وهي:

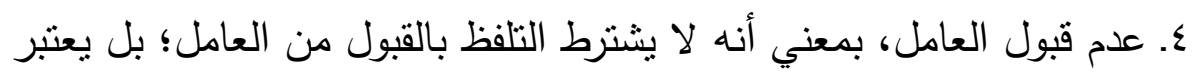
الرضا بالطريقة المتعارف عليها.

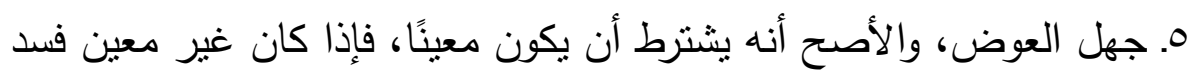

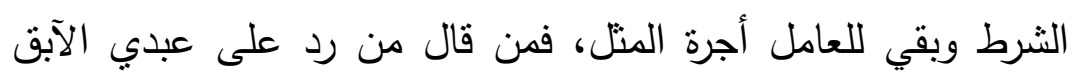

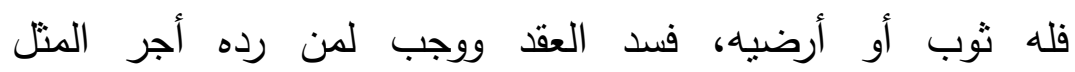
كالإجارة الفاسدة. T. سقوط كل العوض بفسخ العامل، وهذا فيه تفصيل فإن كان الفسخ من

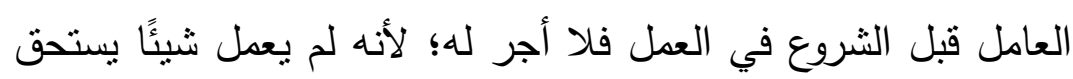

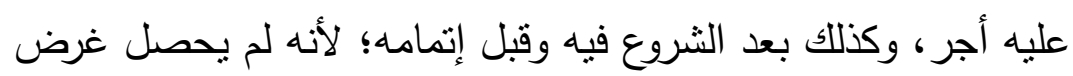

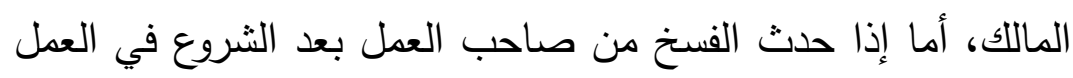


فله أجر المنل، أما إذا فسخ المالك قبل الثروع في العمل فلا شيء للعامل لأنه لم يعمل شيئًا يستحق عليه أجر .

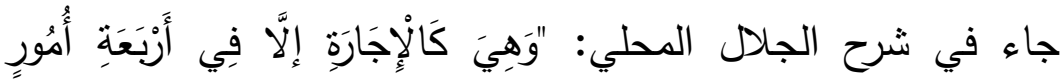

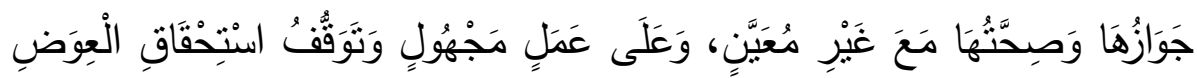

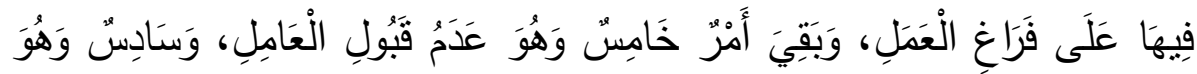

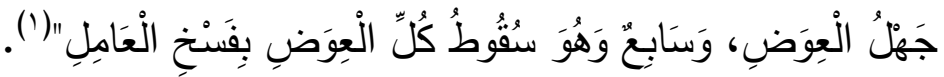
وليس هذا هو المراد بالجعل في الثروط الجعلية، وإنما كان الغرضِ من ذكر تعريفه التقريق بين الجعل الذي هو الأجر على عمل معين، والجعل الوارد في الثروط الجعلية التي سيأتي ذكرها في المطلب الثالث ـ إن إن شاء الله تعالى.

\section{المسألة الثالثة : تعريف الشرط البمعي اصطلاحًا}

جاء في الوجيز في أصول الفقه: الشرط الجعلي: وهو ما اشترطه : المكلف. كما لو اشترطت المرأة تقديم المهر كله أو لو اشترط البائع تشليم المبلغ في مكان ما وتكاليف نقله على المشتري وأمثال ذلك (؟).

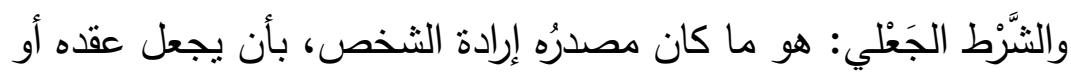

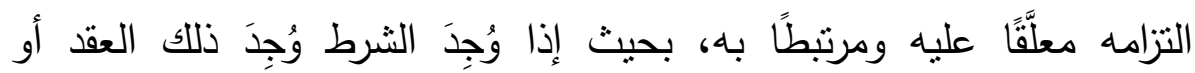

شرح جلال الدين المحلي على منهاج الطالبين مع حاثيتا قليوبي وعميرة

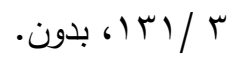

(r) الوجيز في أصول الفقه الإسلامي د/ وهبة الزحيلي /1/1 • ع، ط ب - دار الخير دمشق

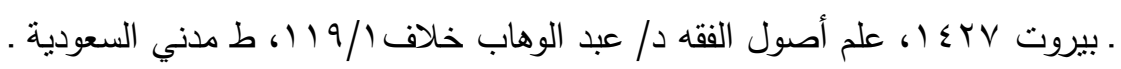

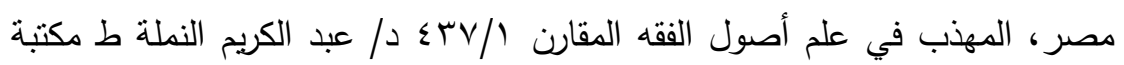
الرشد الرياض • r أهـ. 
الالتزام، وإن لم يتحقق ذلك الثرط، فلا يتحقق المشروط فيكون المشروطُ

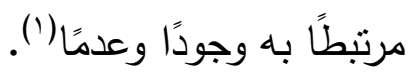

ومثاله: ما لو علَّق الثخص كفالته بأمر بلائمها، فقال للائن:

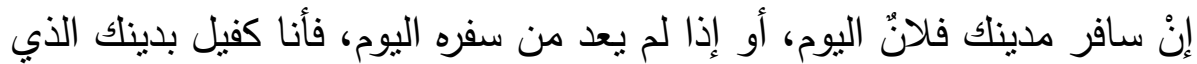

للك عليه.

فإنَّ سَفَر المدين أو عدم عودنه من سفره يصبح شرطًا لثبوت الكفالة

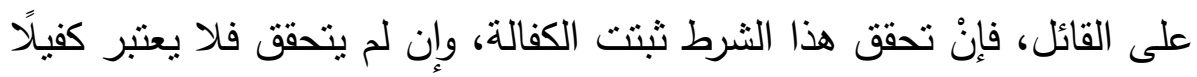

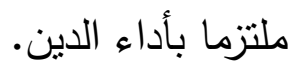

- من خلال هذه التعريفات أفهم أن الثروط الجعلية على ثلاثة أنواعٍ:

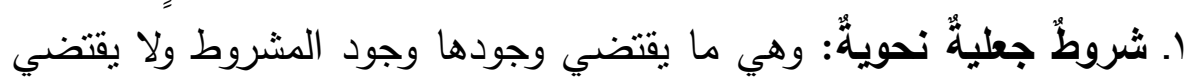
عدمها عدمه. r. شروطُ جعليةٌ وضعيةٌ: وهي ما انشترطه المكلف على نفسه أو على

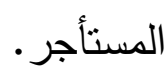

ع. شروطُ جعليةٌ حقيقيةٌ أو شرعيةٌ: وهي ما يتوقف عليها وجود المشروط ولا يلزم من وجودها وجوده. وهي قريبةٌ من النحوية. وإلفرق بين هذه الأنواع: أن الثروط الجعلية الثرعية: ما كانت من وضع الثارع، دون تدخل

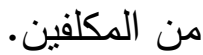

(1) الوجيز في أصول الفقه الإسلامي د/ وهبة الزحيلي /1/1.ع، ط ب - - دار الخير

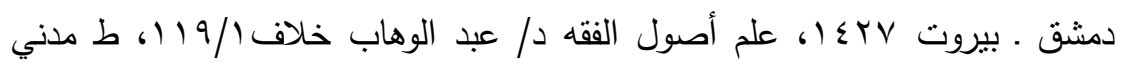

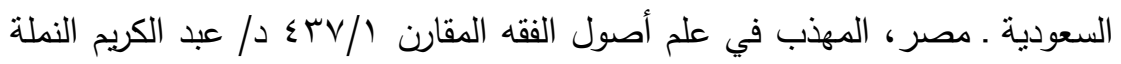

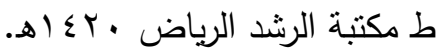


الشرط الجعلي دراسة أصولية وأثره في الفروع الفقهية في باب الإجارة

أما الشروط الجعلية النحوية: فهي التي لابد من نوافر أدوات الثرط فيها ووجود فعل الشرط وجواب الثرط، وهي موافقة للشروط الثرعية. أما الشروط الجعلية والوضعية: فما كانت من وضع المكلف دون تذخل للشرع فقد تكون موافقة للشروط الثرعية وقد تكون مخالفة لها. والذي يعنيني من هذه الثروط هي الثروط الجعلية الوضعية فقط وذللك لبيان الحكم الثرعي الوارد فيها. * $\quad * \quad * \quad * \quad * \quad *$ 


\title{
المطاب الثالث
}

\section{أدوات الشرط واختلاف العلهاء فيها}

\author{
وفيه ثلاث مسائل: ألائ \\ المألة الأولى: أدوات الشرط. \\ المسألة الثانية: أقسام أدوات الثرطات الثرط. \\ المسألة الثالثة: الخلاف الوارد في أدوات الثرط.

\section{المسألة الأولى: أدوات الشئرط الدوط}

وضع علماء اللغة للشرط أدوات يعرف بها، وتبعهم عليها علماء

الأصول، وهي على النحو التالي:

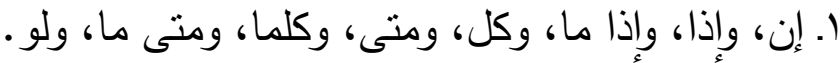

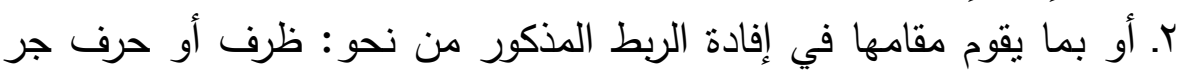

غير لام التعليل.

س. أو استثناء (بإلا أن) إذا تقدمه ما لا يحتمل التأقيت كالطلاق.

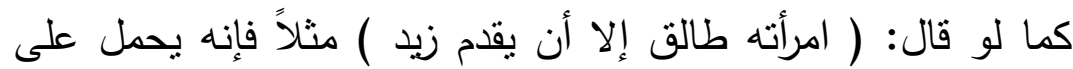

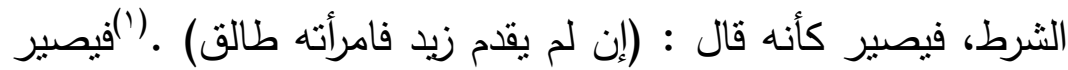

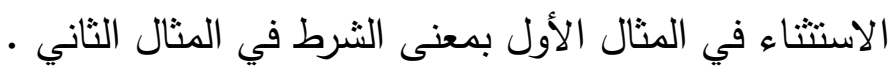

ع. وزاد البعض (حيثما، وأينما)(؟).

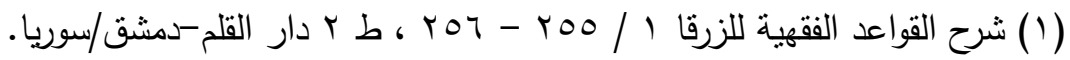

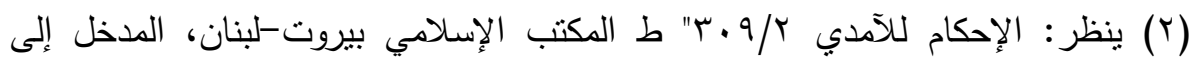

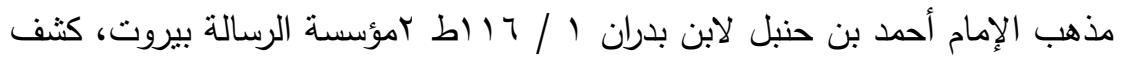
الأسرار عن أصول فخر الإسلام البزدوي / / /

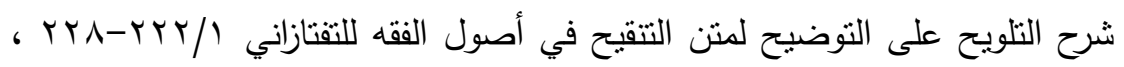

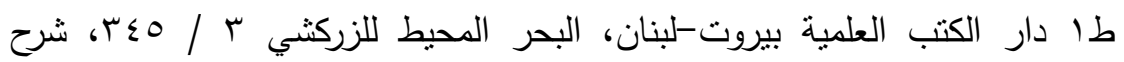
الكوكب المنير لابن النجار ץ / • ع ب ، طب مكتبة العبيكان. 


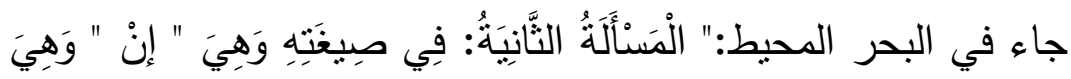

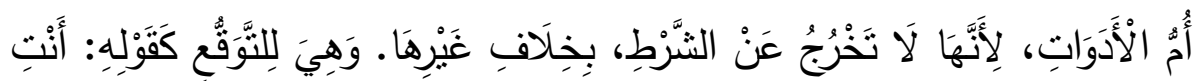

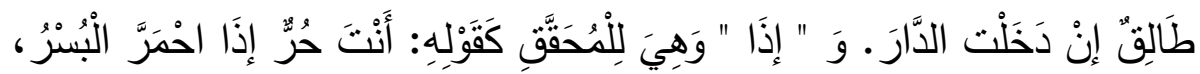

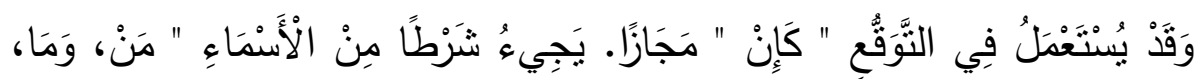

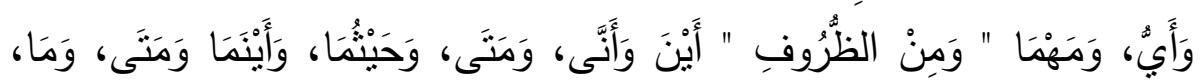

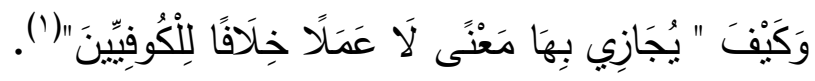

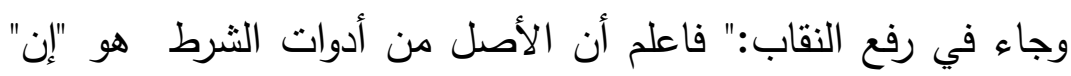

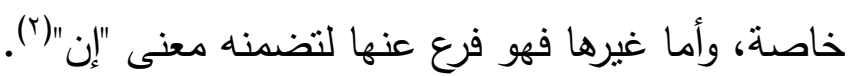

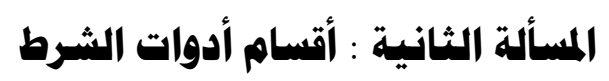

اتفق جمهور الأصوليين والحنفية على أن أدوات الثرط تتقسم إلى قسمين:

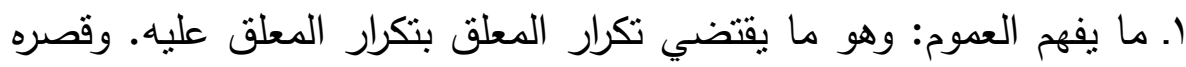

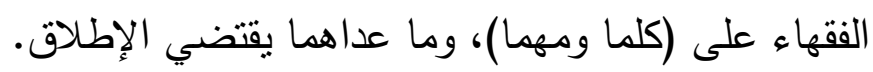

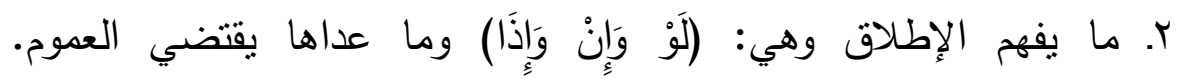

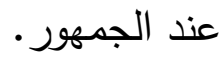

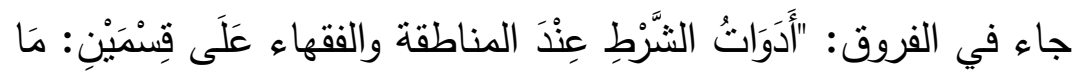

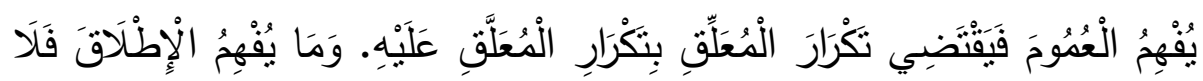

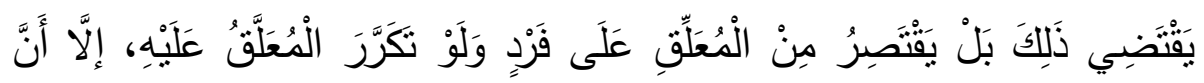

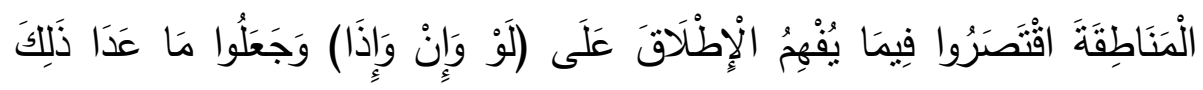

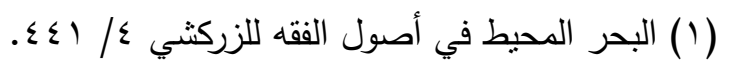

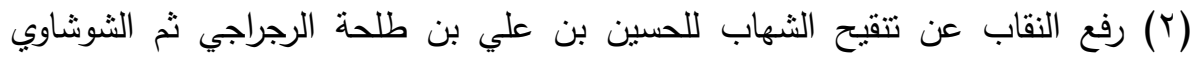

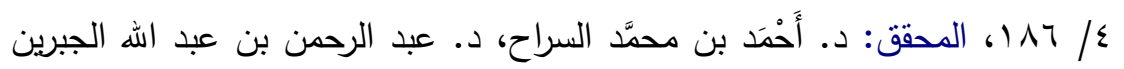

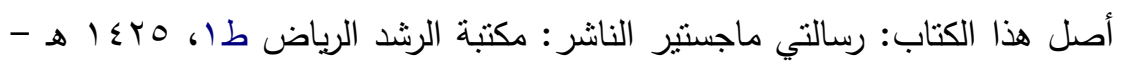

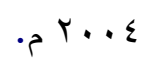




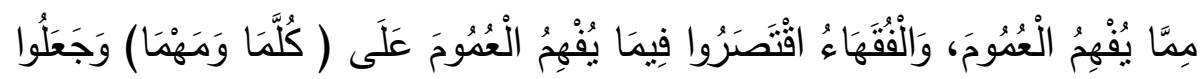

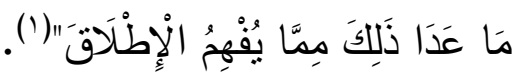

\section{المسألة الثالثة : الخلاف الوارد في أدوات الشرط}

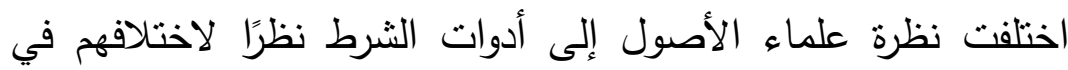

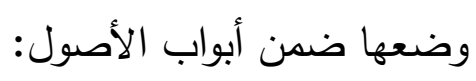

1. فمنهم من وضعها ضمن باب تقسيم اللفظ فسماها ( كلمات الثرط)(ب).

كالتقنازاني.

r. ومنهم من ذكرها ضمن باب العموم والخصوص واعنبرها من أدوات العموم

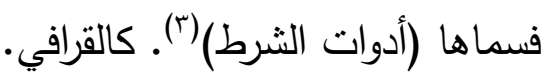

rا. ومنهم من ذكرها ضمن حروف المعاني فجمع بين كل المسميات فقال هي: (ألفاظ وكلمات وحروف الثرط). وذكر أن الأصل فيها أنها حروف. وإليه أنثار البزدوي في كثف الأسرار .

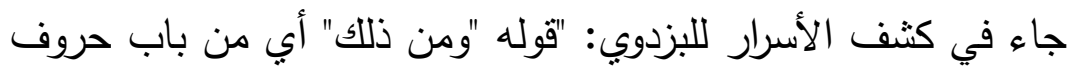

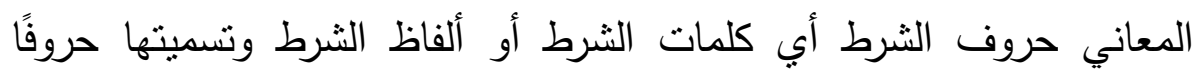
باعتبار أن الأصل فيها كلمة، إن وهو حرف فهو الأصل في هذا الباب"(\{).

(1) أنوار البروق في أنواء الفروق للقرافي / /ع. 1.

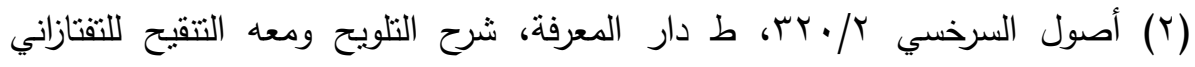

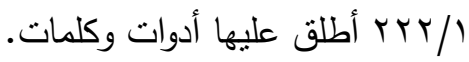

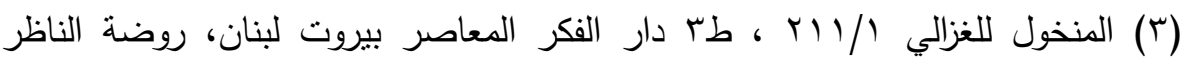

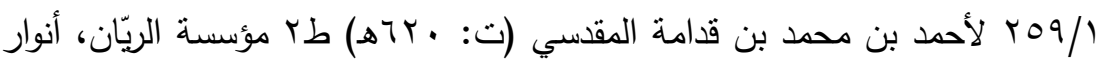

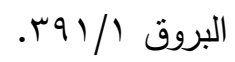

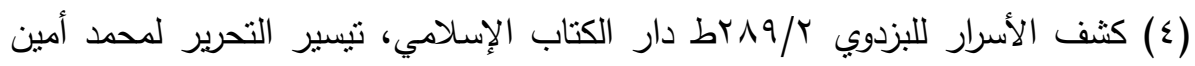

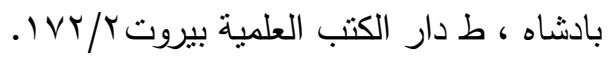


ومن خلال النظر في اختلاف هذه المسميات نجد السبب في هذا

$$
\text { الاختلاف يرجع إلى عدة أسباب منها: }
$$

ا. اختلافهم في تصنيفها تحت أبواب أصول الفقه.

r. أن من أطلق عليها أدوات أو كلمات نظر إلى أن صيخ الشرط منها ما هو

اسم ومنها ما هو حرف والجميع من أقسام الكلمة (').

r. ومن أطلق عليها حروف الثرط نظر إلى أن الأصل في أدوات الشرط (إن)

$$
\text { وهي حرف (r). }
$$

ع. ومن أطلق عليها ألفاظ الثرط نظر إلى اقترانها بفعل الثرط وهو علامة عليه (r).

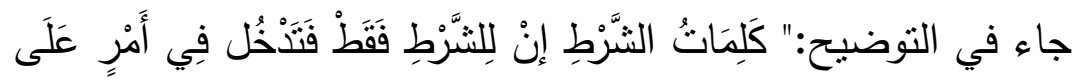

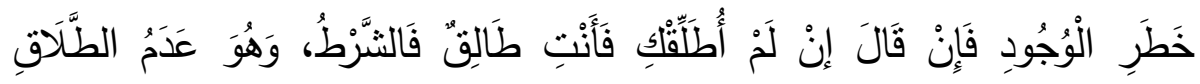

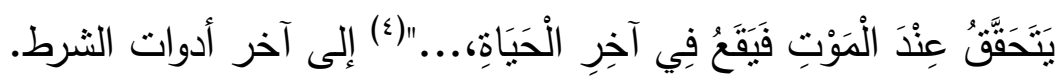

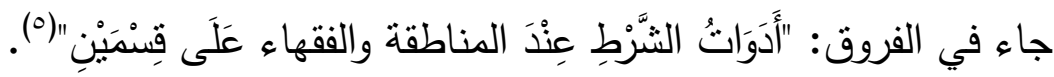

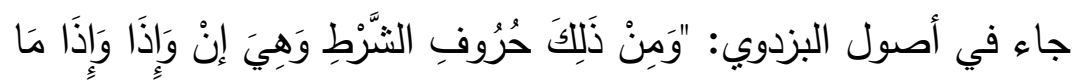

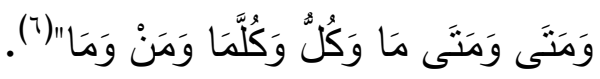

(1) حروف المعاني د/ محمود سعد /9 ؟ ب، الثرط عند الأصوليين د/ الداية /عه.

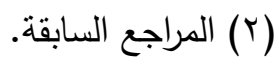

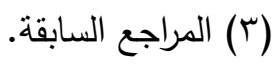

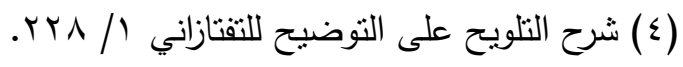

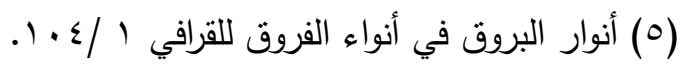

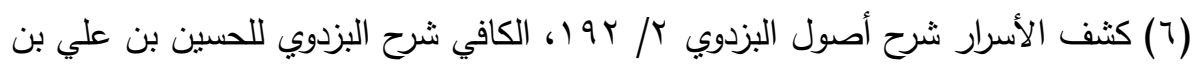

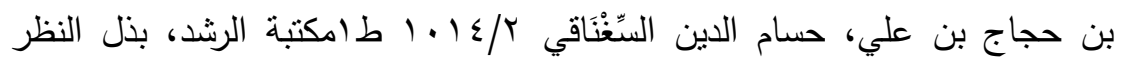

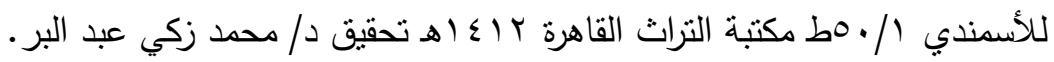




\section{المطاب الرابع}

تعريف الإجارة لغة.واصطلاحًا

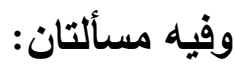

المسألة الأولى: تعريف الإجارة لغةًة.

المسألة الثانية: تعريف الإجارة اصطلاحًا.

المسألة الأولى : تعريف الإجارة لغةًة.

وردت مادة (أجر) في اللغة بعدة معان منها:

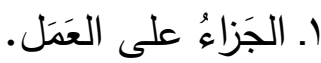

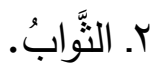

وقد فرّق بينهما بفروق منها:

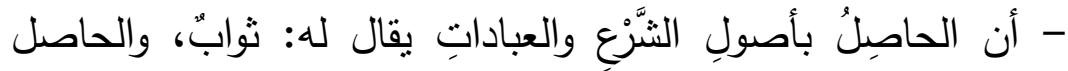

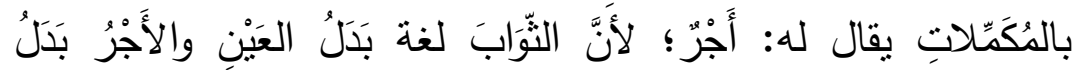

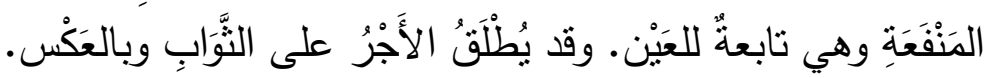

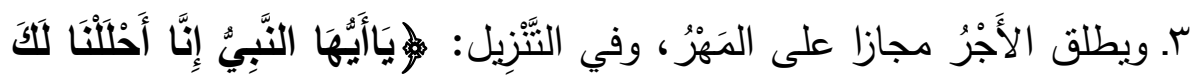

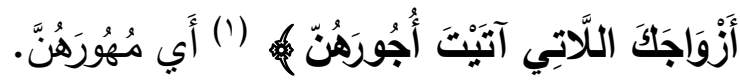

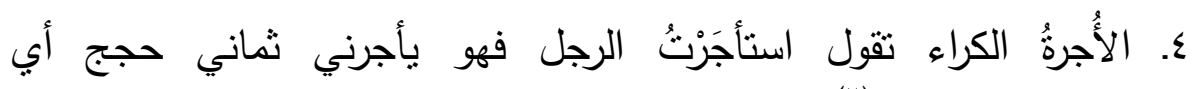

يصير أجيري(')

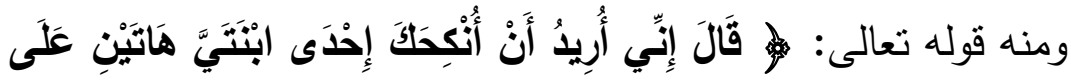

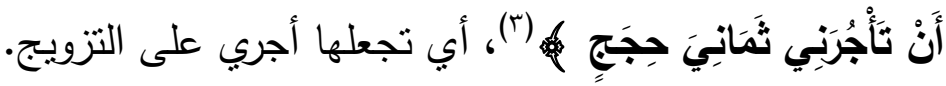

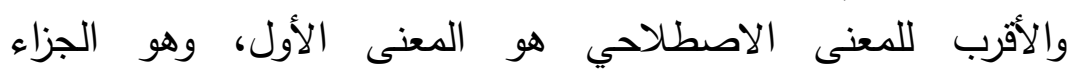

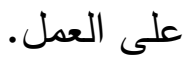

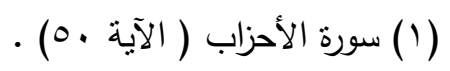

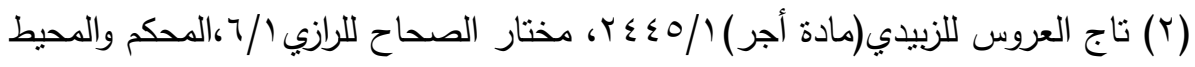

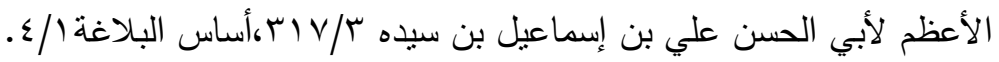

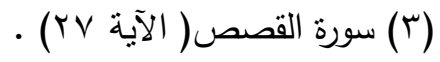




\section{المسألة الثانية : تعريف الإجارة اصطلاحًا}

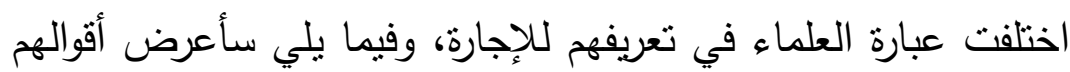

على وجه الإجمال، ثم أذكر أقوالهم بالتفصيل: ا. منهم من عرفها بأنها: عقدّ على تمليك منفعة العين؛ لأنها التي يستوفى منها المنفعة.

r. ومنهم من عرفها بأنها: عقدٌ على منفعة؛ لأنها هي التي يجوز التصرف فيها ولأن الأجر يدفع في مقابلة المنافع.

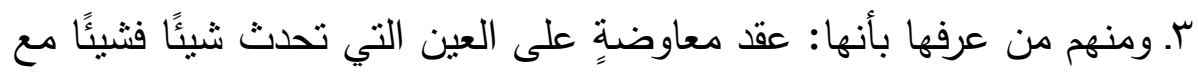
بقاء أصلها كالمنفعة. بمعنى أن عقد الإجارة كما يأني في المنفعة يأني كذلك في العين التي تحدث شينًا فنشيًًا مع بقاء أصلها. وهم ابن القيم وابن تيمية.

\section{وفيسما يلبي عرض لأقمالهم:}

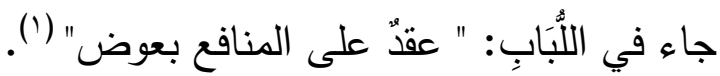

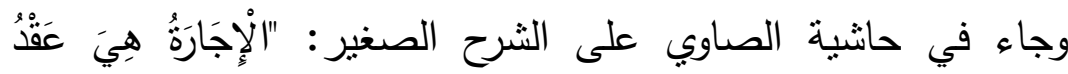

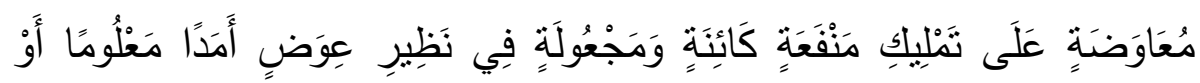

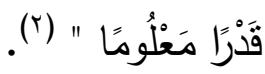

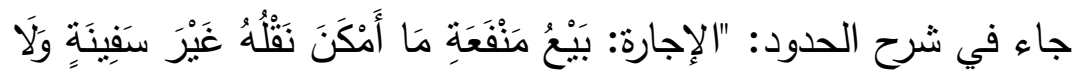

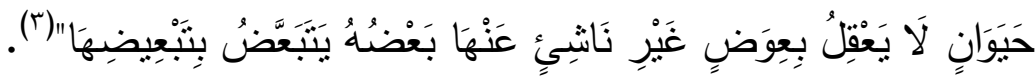

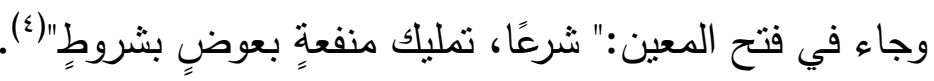

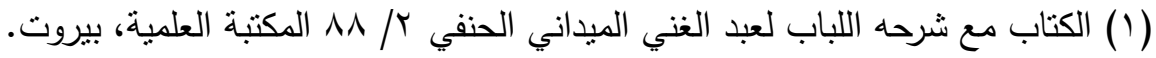

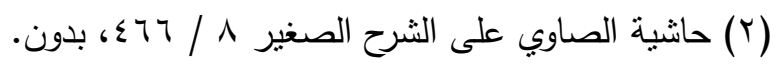

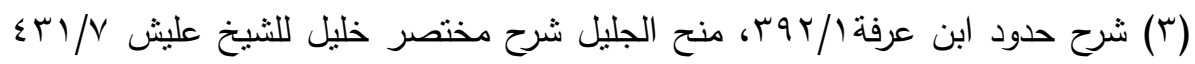
بدون.

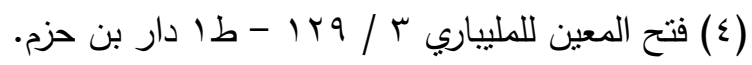


وجاء في حاشيتا قليوبي- وعميرة: "الْإجَارَةُ هِيَ تُمَليك مَنْفَةِة بَعُوضٍ،

بشنُرُوطٍ "(')

جاء في شرح زاد المستقنع للشنقيطي: " الإجارة عقد معاوضةٍ على

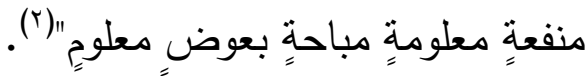

من خلال التعريفات السابقة تبين أن اختلاف الفقهاء في تعريف

الإجارة كان بناء على اختلافهم في محل عقد الإجارة وذلك على ثلاثة أقوال:

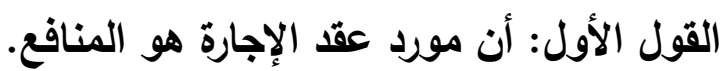

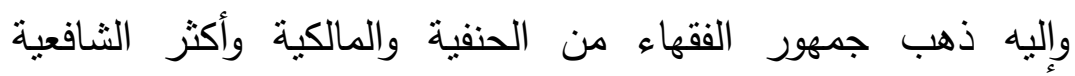

والحنابلة(r): أن مورد عقد الإجارة هو المنافع لأنها هي التي يجوز التصرف

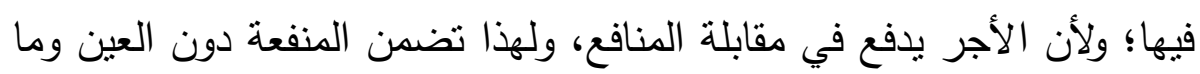
كان العوض في مقابلته فهو المعقود عليه.

\section{القول الثاني: أن هورد عقد الإجارة هو تمايك هنافع العين.}

وإليه ذهب بعض الثافعية ومنهم أبو إسحاق المروزي(أ)، لأن المنافع

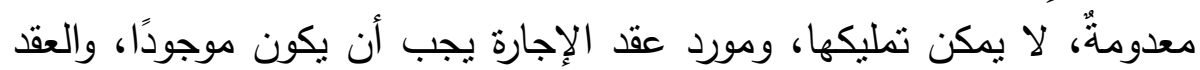

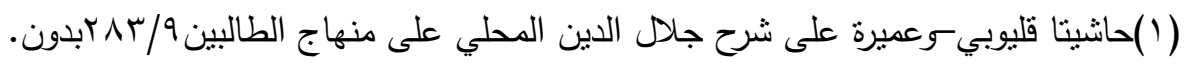

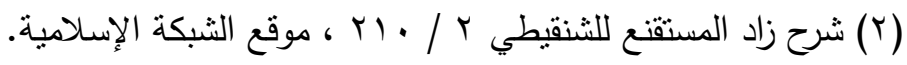

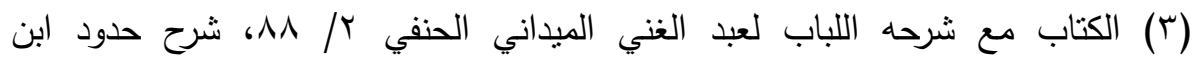

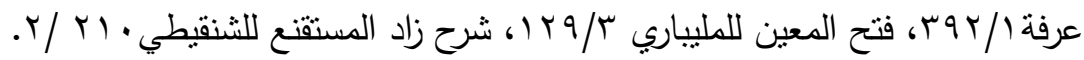

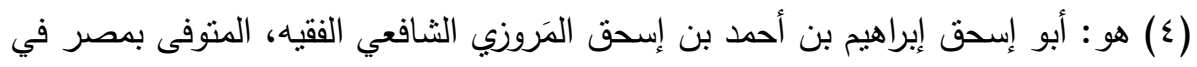
رجب سنة أربعين وثلاثمائة.

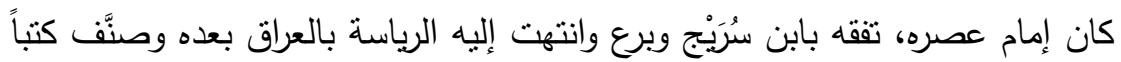

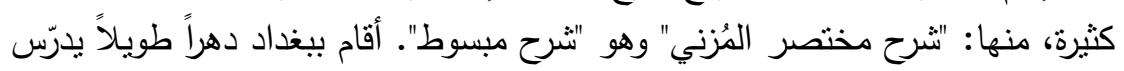

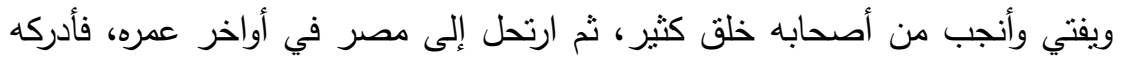

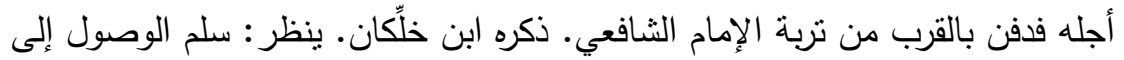

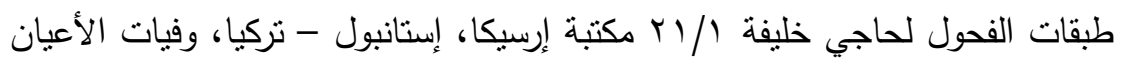

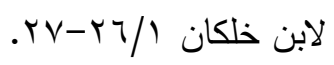


أيضًا يضاف إلى العين لأنها التي تسنوفى منها المنافع فوجب أن يكون تمليك منافع العين مورد العقد.

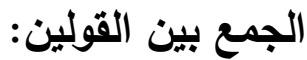

\section{ولا يوجد في الحقيقة خلافت بين القولين السابقين وذلك للأسباب التالية:}

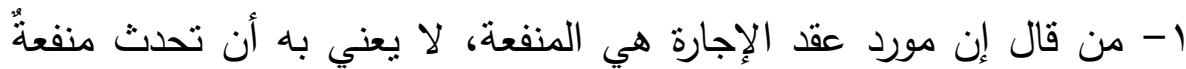
بدون عينٍ، ولكن مراده هو المنفعة المستفادة من العين. لذلك فهو لا يقطع النظر عن العين بل يجب أن نسلم وتمسك مدة هرة

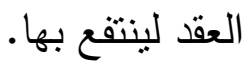
ץ- ومن قال إن مورد عقد الإجارة تمليك منافع العين، لا يعني به أن العين تملك بالإجارة كما تملك بالبيع، وليس مراده ومقصوده من الإجارة هو تمليك العين؛ بل تمليك منافعها. لذللك فهو لا يقطع النظر عن المنفعة المطلوب استيفاءها. فالنتيجة الواحدة لهذين القولين إن محل عقد الإجارة في إجارة الأشياء

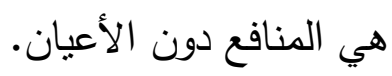
وقد اتفق الفقهاء على اثتراط ألا يتضمن استيفاء المنفعة استهلاك العين مثل استئجار الثمع للاستضاءة به، والصابون للغسل به، فلا تصح الإجارة على ذلك؛ لأن الإجارة عقد على المنافع وهذه لا ينتفع بها إلا بلا

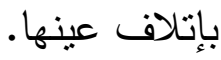
وهذا هو الأصل، وهو أمرّ مقررّ عند جمهور الفقهاء. 


\section{يتخرج على هذا الأصل عدة هسائل هذها:}

ا. لا يجوز عند أكثر الفقهاء إجارة الثجر والكرم للثمر ذاته؛ لأن الثمر عينٌ،

والإجارة بيع المنفعة، لا بيع العين (').

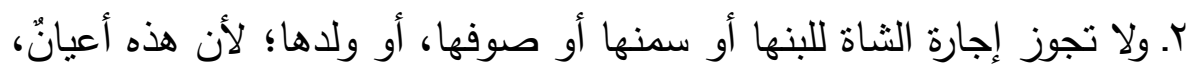

فلا نستحق بعقد الإجارة.

r. ولا تجوز إجارة ماعٍ في نهر أو بئرٍ أو قناةٍ أو عينٍ؛ لأن الماء عين.

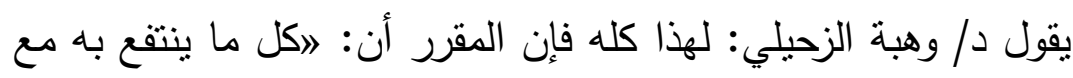

بقاء عينه تجوز إجارته وما لا فلاه (r). واستثنوا إجارة الظئر (المرضع) للضرورة وأجاز المالكية كراء الفحل

للنزو على الإناث وأباح أكثز العلماء أجرة الحجام للحاجة (†).

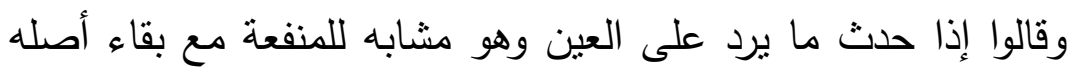

فيمكن القول بجوازه استثناء من القاعدة العامة، ورخصة للضرورة أو الحاجة. وذلك منل لبن الظئر وماء البئر وغيرهما فتدخل على طريق التبع

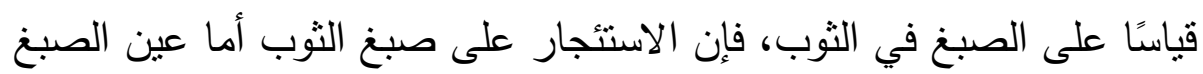

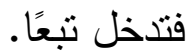
القول الثالث: أن مورد عقد الإجارة كما يأني في المنفعة يأني كذلك في العين التي تحدث شينًا فثينًا مع بقاء أصلها.

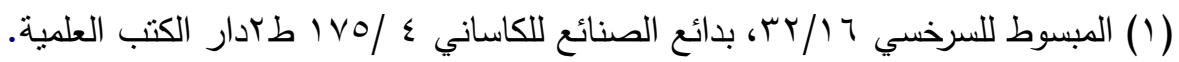

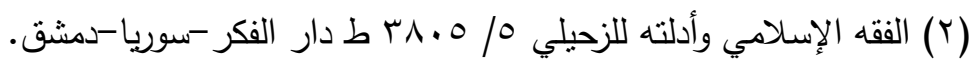

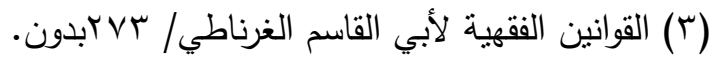


وإليه ذهب ابن تيمية(') وتلميذه ابن القيم(؟)، وخالفا به من قبلهم، وقالا بجواز عقد الإجارة على العين التي تحدث شييًا فثييًًا مع بقاء أصلها كالمنفعة. فتصح الإجارة على لبن الظئر وماء البئر؛ لأن الماء واللبن لما كان حدوثهما شيئًا بعد شيء مع بقاء الأصل كانا كالمنفعة. فقد قاسا الأعيان التي تتجدد مع بقاء الأصل على المنفعة لاشتراكهما في علة الحدوث والتجدد مع بقاء الأصل.

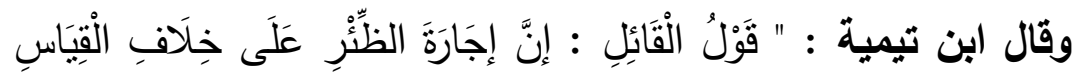

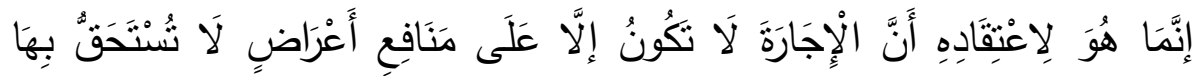

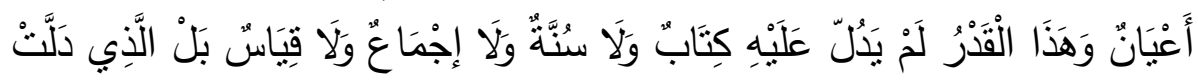

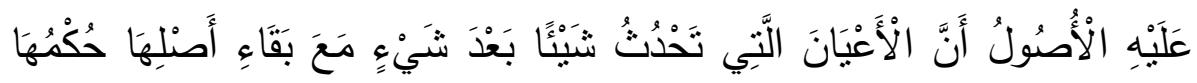

(1) هو: أحمد بن عبد الحليم بن عبد السلام الحراني الدمشي الحنبلي، أبو العباس،

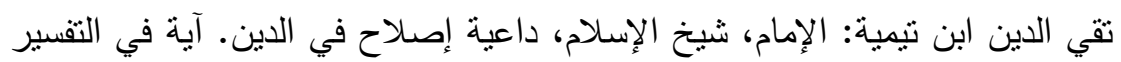

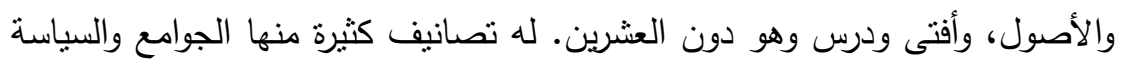

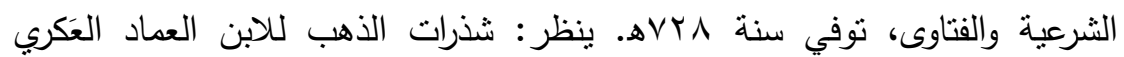

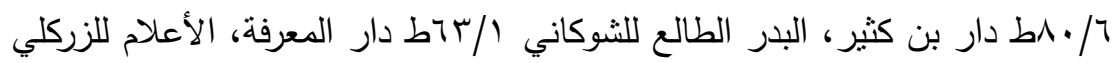
. $1 \leq \varepsilon / 1$

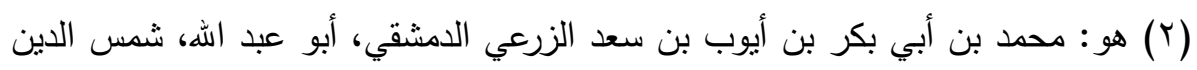

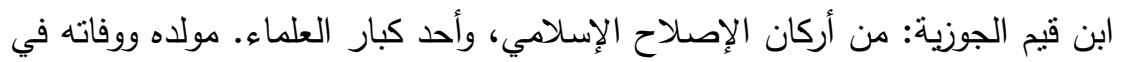

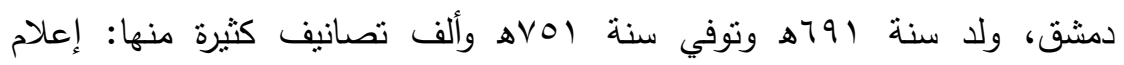

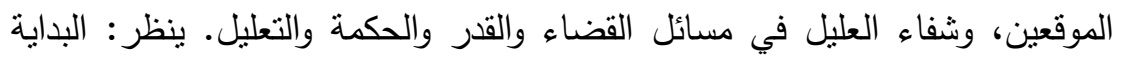

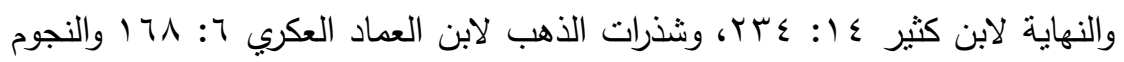

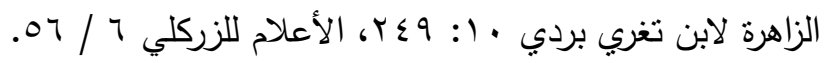




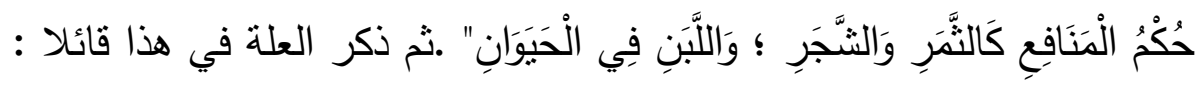

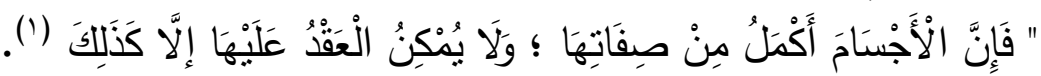
ووافقه على ذلك تلميذه ابن القيم في إعلام الموقعين حيث قال: "

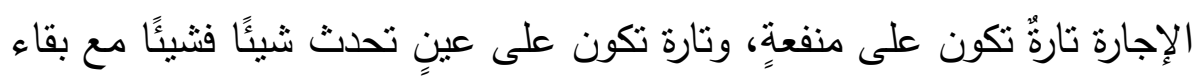

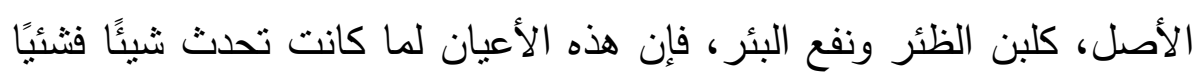

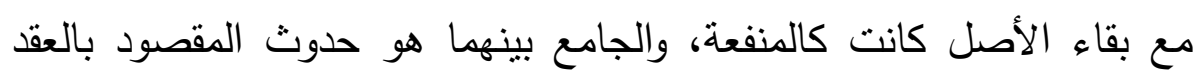

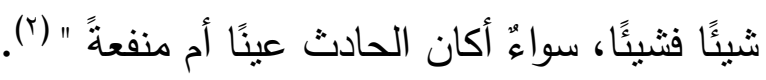

الراجح: والأخذ برأي ابن القيم ـ رحمه الله ـ وهو جواز عقد الإجارة على العين

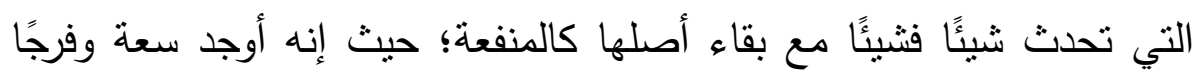

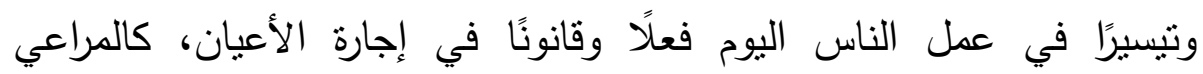

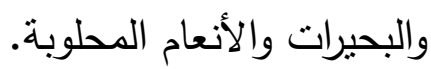

* $\quad * \quad * \quad * \quad * \quad *$

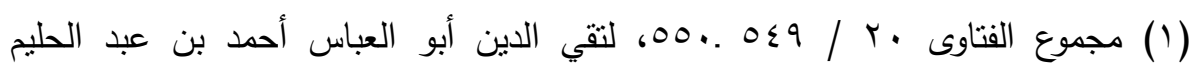

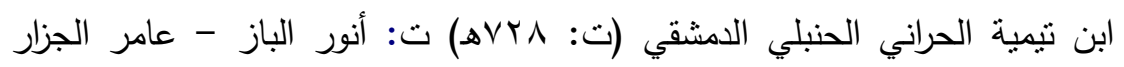

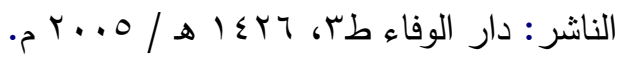

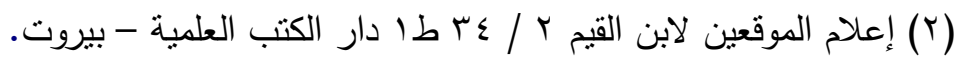




\section{الإطلب الخامس \\ مشروعية الشرط البعلي}

اختلف جمهور الأصوليين في مشروعية الشرط الجعلي إلى ثلاثة

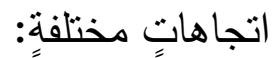

ا. ما بين مانع يرى عدم جواز وضع أي شرط ليس في كتاب الله ولا سنة

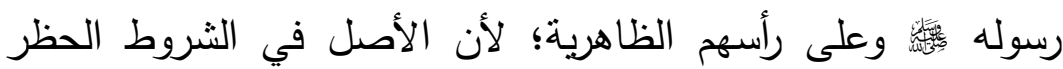

$$
\text { عند هم (') }
$$

r. ومن يرى التضييق في هذا المجال؛ لأن الأصل في الثروط الحظر إلا ما

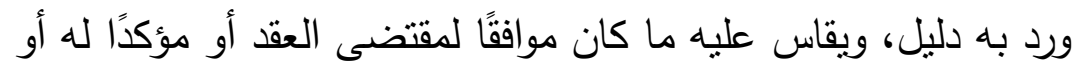

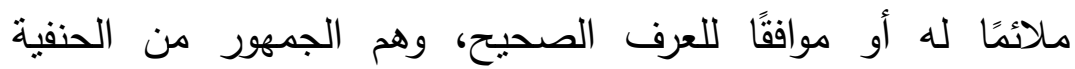
والمالكية والثافعية و بعضٌ من الحنابلة، فهم متفقون مع الظاهرية في أن الأصل في الثروط المنع لكنهم أباحوا من الشروط ما كان موافقًا لمقتضى العقد، لكن الظاهرية لم يجيزوا إلا ما ورد به نصُ فقط ولم

$$
\text { يجيزوا القياس عليه (r). }
$$

(1) الإحكام في أصول الأحكام لابن حزم 0/ با، ت أحمد محمد شاكر، ط دار الآفاق

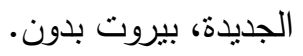

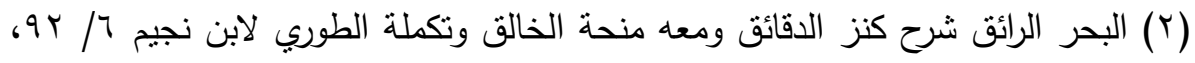

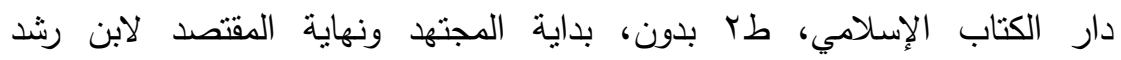

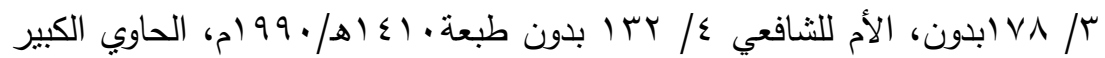

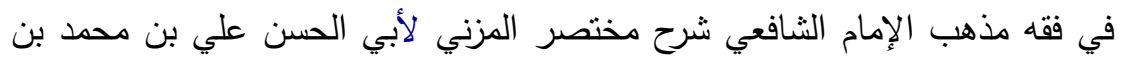

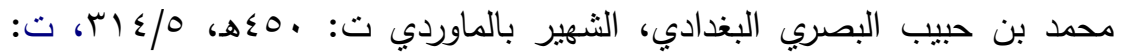

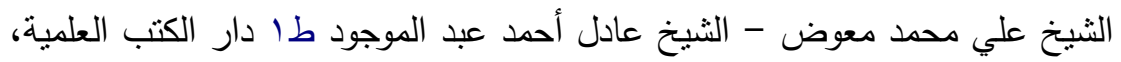

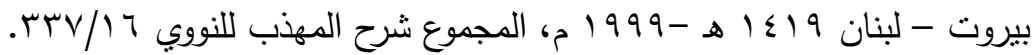




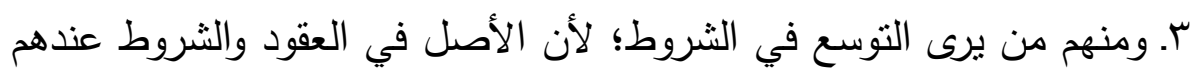

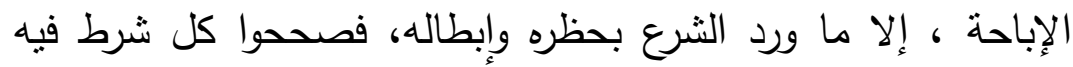
منفعةٌ لأحد المتعاقدين، ولم يستثنوا إلا بشرط أن يكاد يكون منافيًا

لمقتضى العقد (').

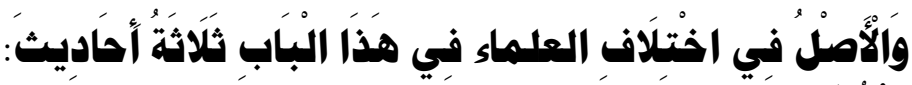

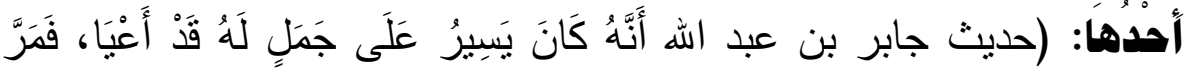

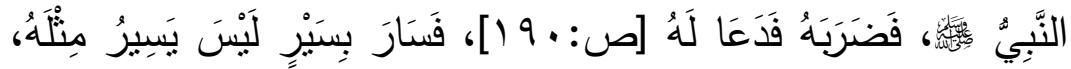

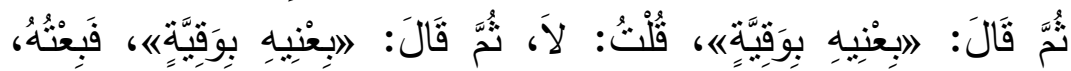

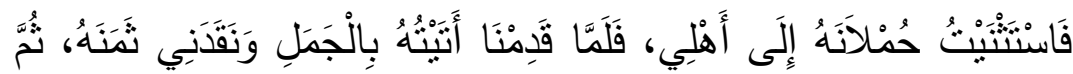

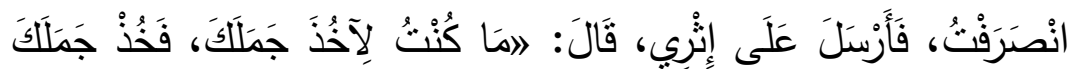

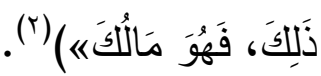

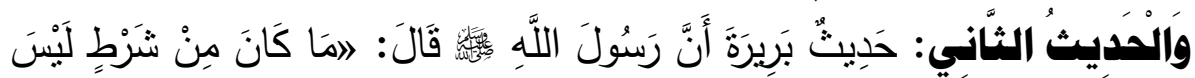

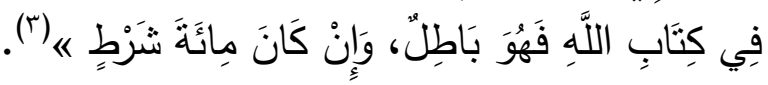

(1)نظرية العقد = العقود / / ب Y لنقي الدين أبو العباس أحمد بن عبد الحليم بن

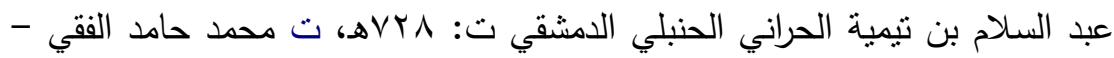

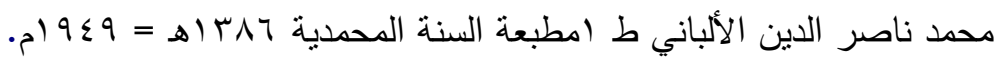

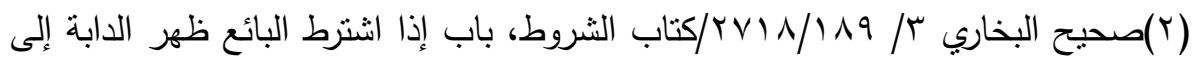

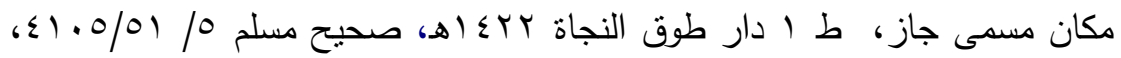

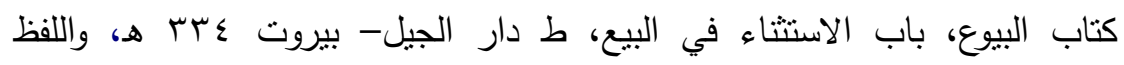

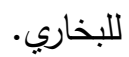

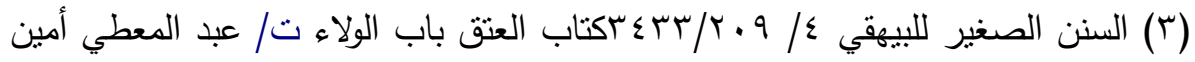

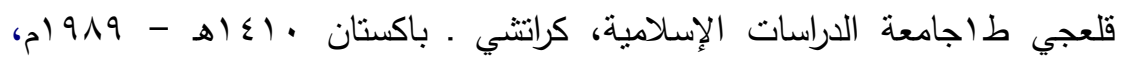

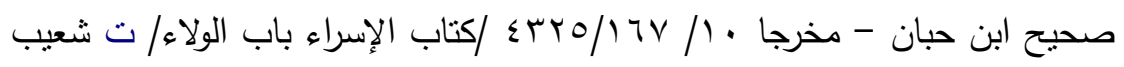

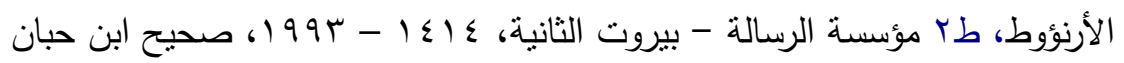

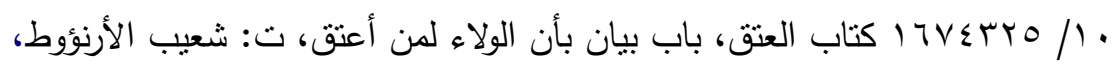

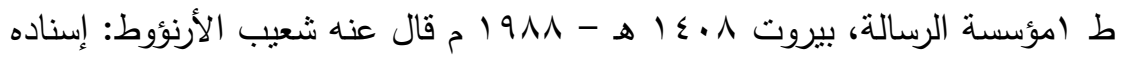
صحيح على شرطهما. 


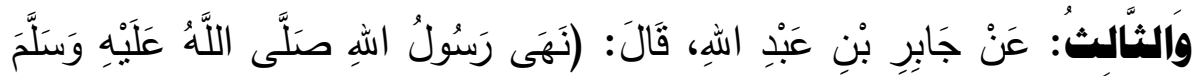

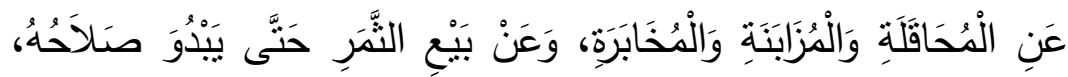

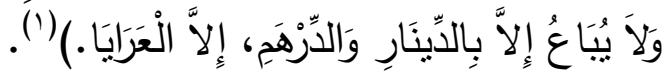

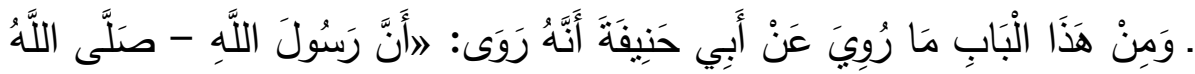

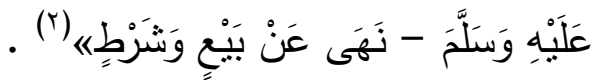

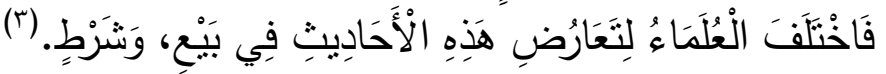

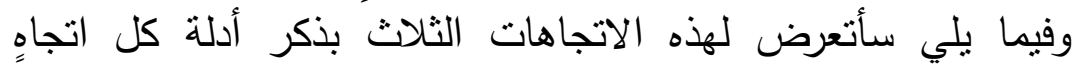
ومحاولة التوفيق بينها أو التزجيح حسب التعضي لهذه الآليل:

\section{الاتجاه الأول: اتجاه المانعين: - الماني}

وعلى رأسهم الظاهرية، يرون أن الأصل في الثروط الحظر ، ولانيجة يجوز اشتراط أي شرط لم يرد في الكتاب أو السنة.

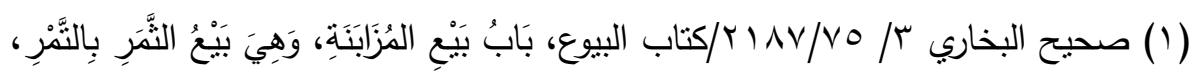

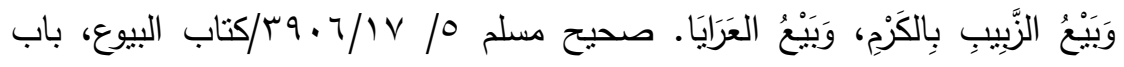
جامع ما جاء في المزارعة، واللفظ لمسلم.

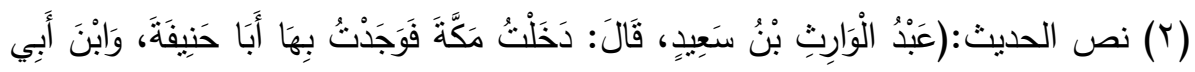

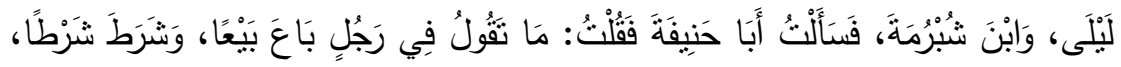

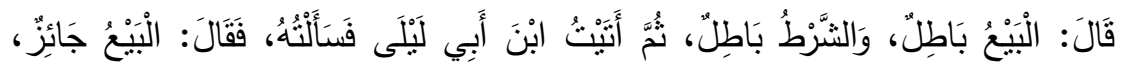

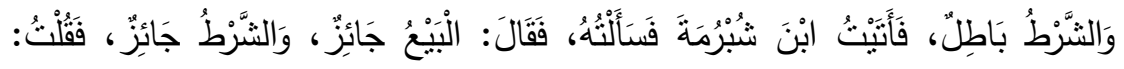

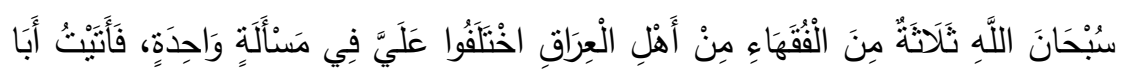

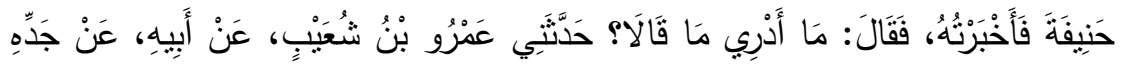

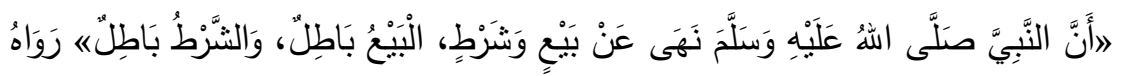

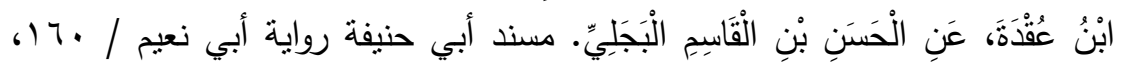

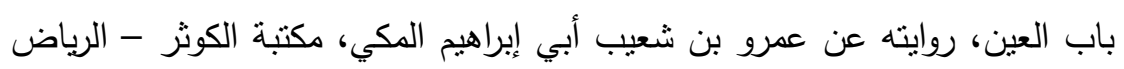

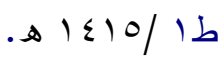

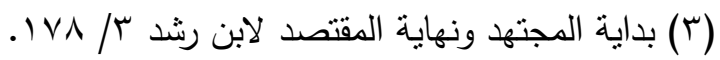




\section{واستدلوا على ذلك بعدة أدلة هن القرآن والسنة.}

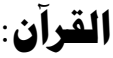

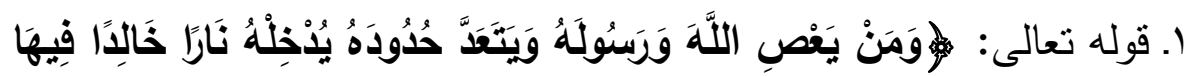

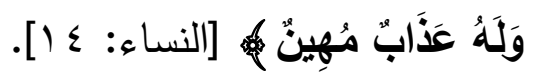

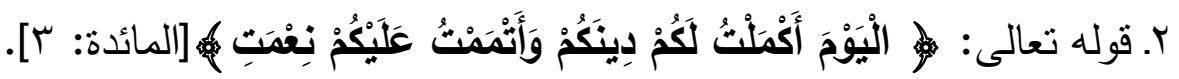

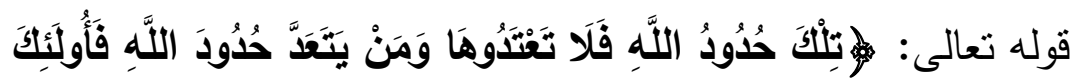

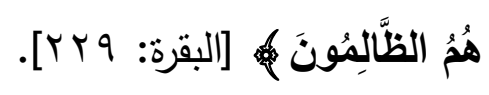

\section{واستدلوا هن السنة بها يلي:}

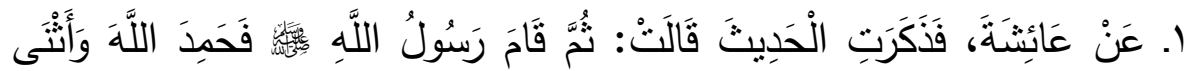

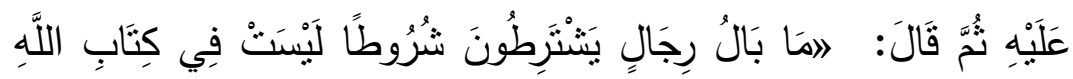

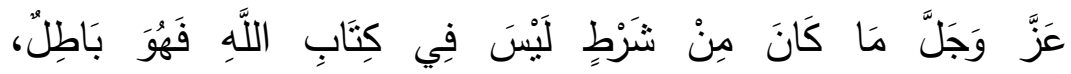

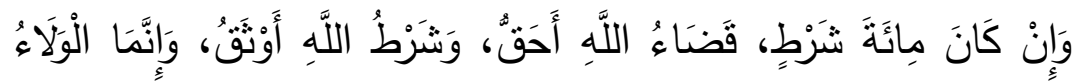

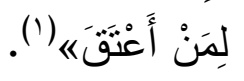

وجه الدلالة: يقول ابن حزم: "فهذه الآيات وهذا الخبر براهين قاطعة في إبطال

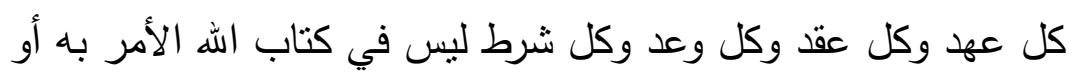

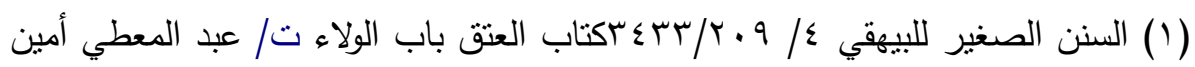

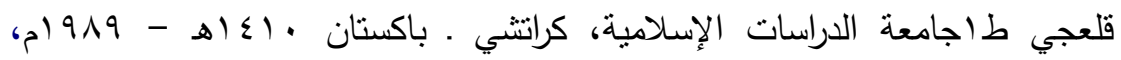

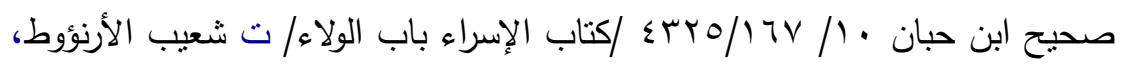

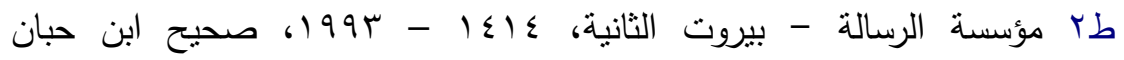

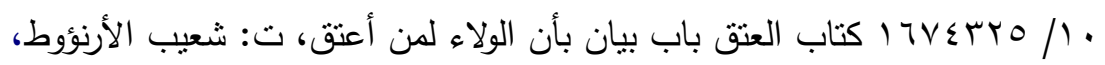

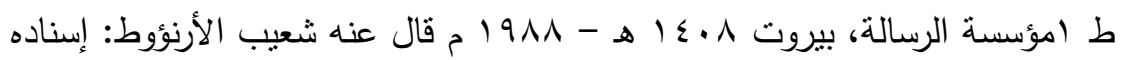

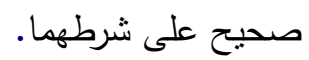


النص على إباحة عقد؛ لأن العقود والعهود والوعود شروط واسم

الثرط يقع على جميع ذلك"(').

الاتجاه الثاني: الاضيقين: وهم الجمهور من الحنفية والمالكية والثافعية

وبعض الحنابلة(r) يرون أن الأصل في الثروط الحظر إلا ما ورد

دليلّ يجيزه من كتاب أو سنة، وهم بهذا ضيقوا نطاق الثروط وقصروه

على ما ورد في الكتاب والسنة كما فعل الظاهرية، لكنهم توسعوا عنهم

قليلًا بجواز القياس على هذه الشروط الواردة في الأدلة.

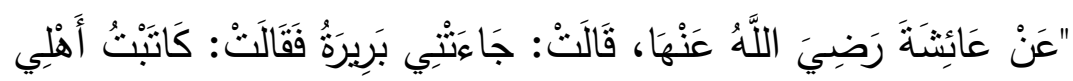

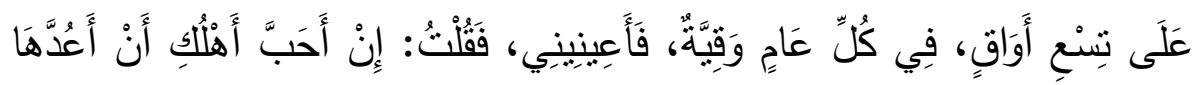

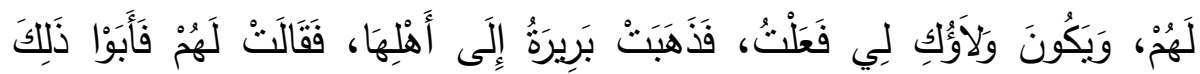

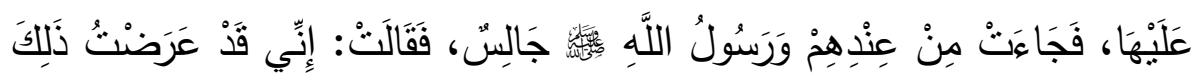

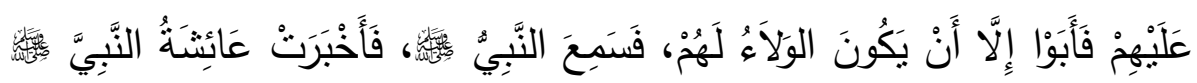

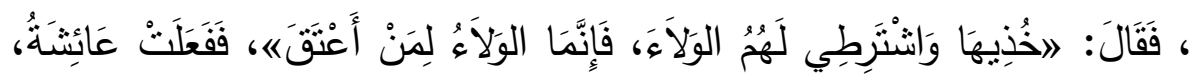

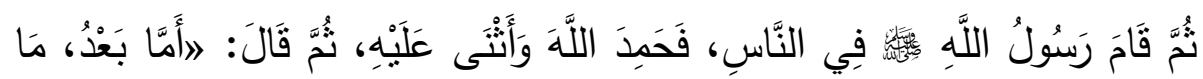

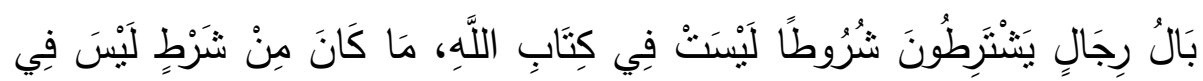

(1) الإحكام في أصول الأحكام لابن حزم 0/ با، ت أحمد محمد شاكر، ط دار الآفاق

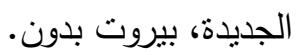

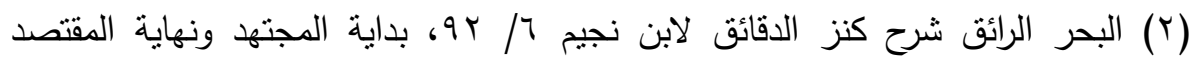

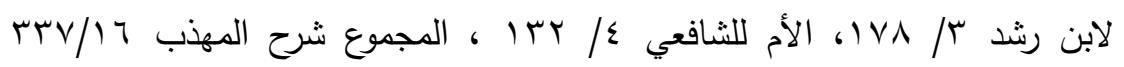

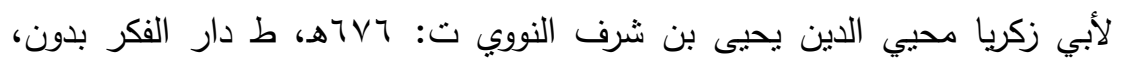

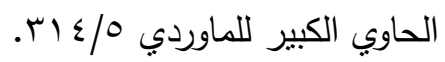




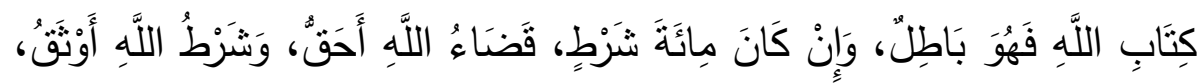

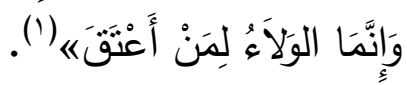

وجه الدلالة: استثلوا بهذا الحديث من وجهين:

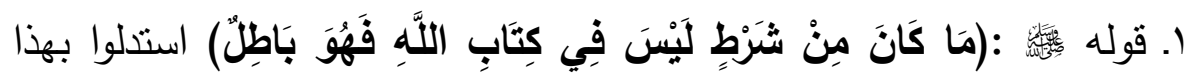

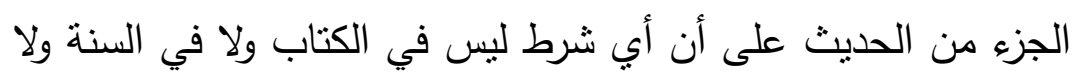

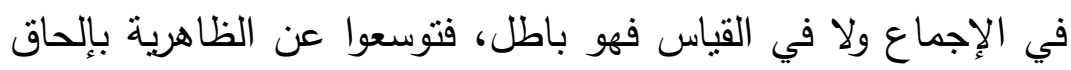

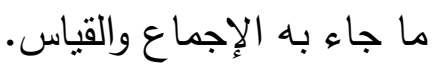

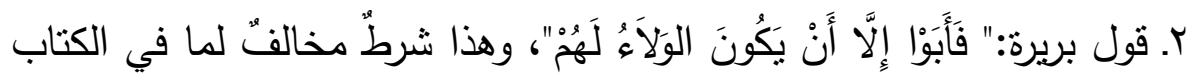

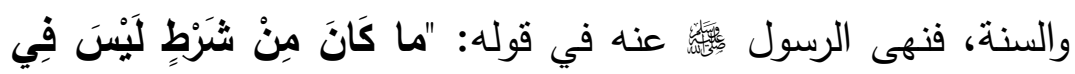

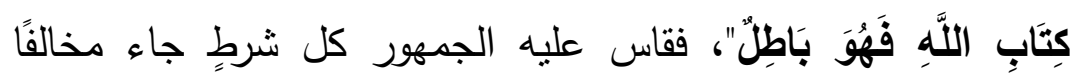

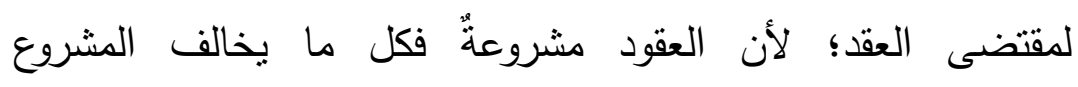

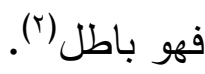

جاء في المجموع شرح المهذب: "إذا شرط في البيع شرطًا نظرت فإن

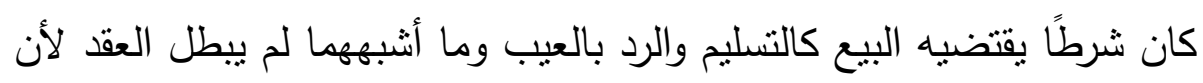

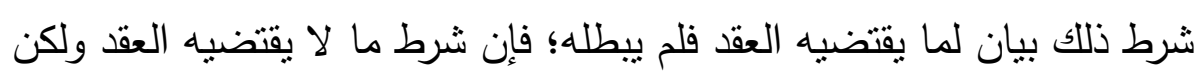

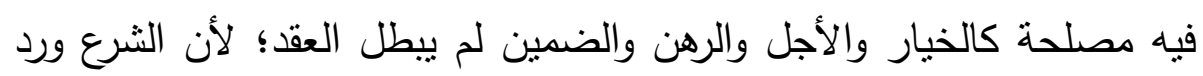

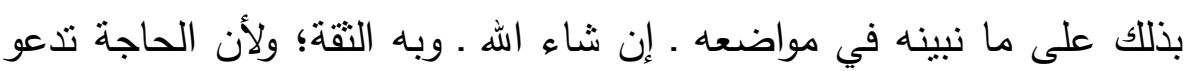
إليه فلم يفسد العقد"(").

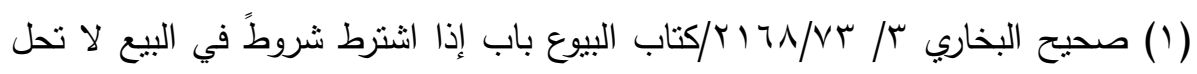

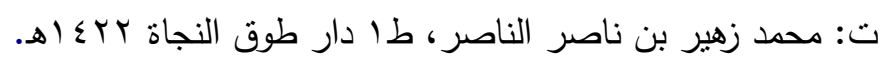

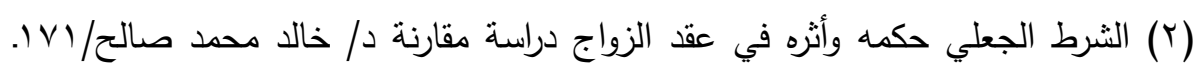

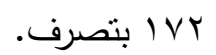

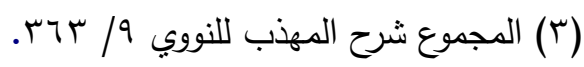


الاتجاه الثالث: اتجاه الموسعين وهم الحنابلة وعلى رأسهم ابن القيم وابن تيمية:

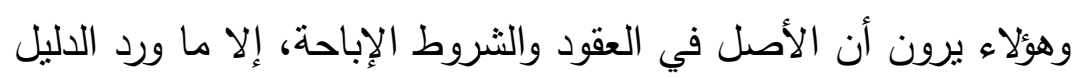

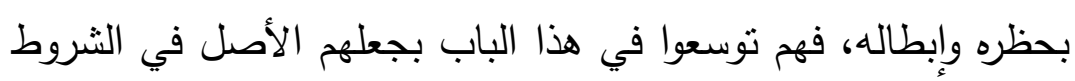

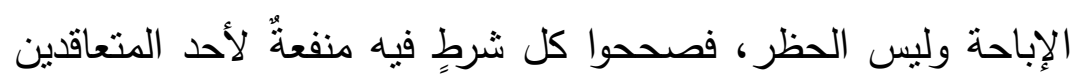
ولم يستثثوا إلا ما ورد دليل من الثرع بحظره. يقول ابن تيمية في نظرية العقد : "وقد بينا في غير موضع أنس أن الأصل في العقود الإباحة فلا يحرم منها إلا ما حرمه اله ورسوله ولم يحرم الله عقدًا

فيه مصلحةُ للمسلمين بلا مفسدة تقاوم ذلكل" ('). وكذلك في باب النكاح تمسكًا بما روى عقبة عن النبي ـ صلى الله عليه وسلم • وسأذكره في الأدلة فيما يلي: أدلتهـهم: استدلوا بعدة أدلةِ من القرآن والسنة: فمن القرآن:

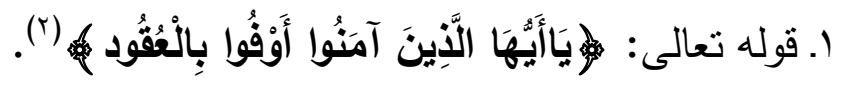

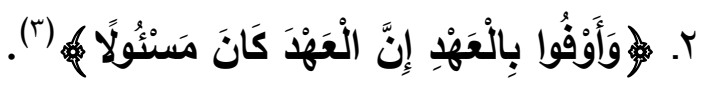

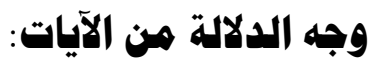
دلت هذه الآيات وغيرها من الآيات التي تفيد وجوب الوفاء بالعقود

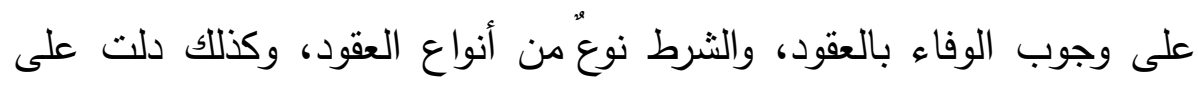

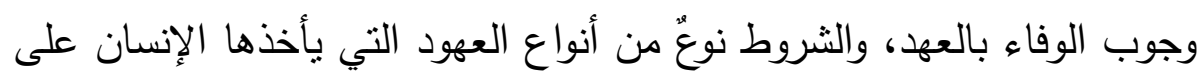

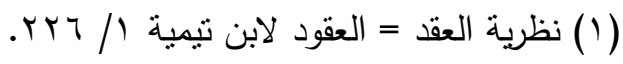

$$
\begin{aligned}
& \text { (r) سورة المائدة (الآية ()). }
\end{aligned}
$$

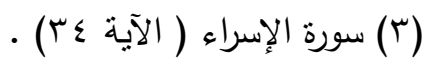


نفسه، ويجب عليه الوفاء به حتى لا يتعرض للمسألة والعقوبة من الله يوم القيامة(')

\section{وهن السنة:}

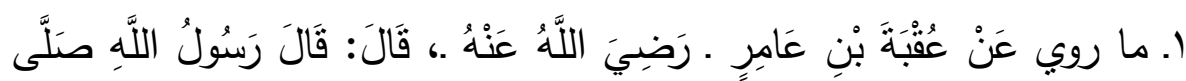

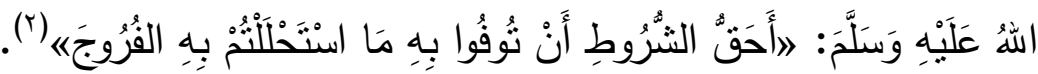

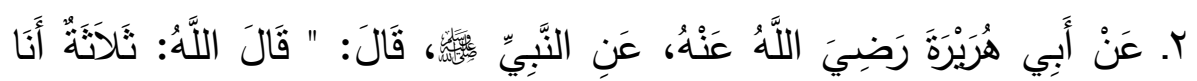

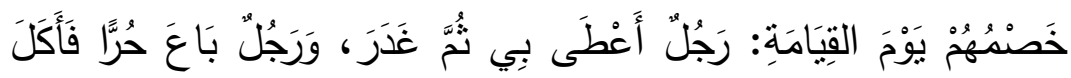

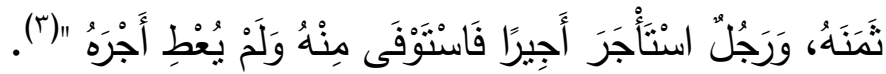

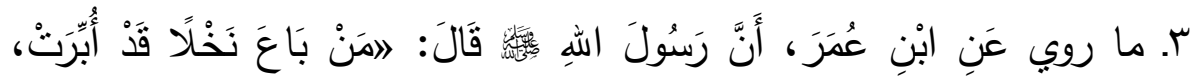

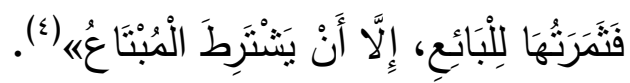

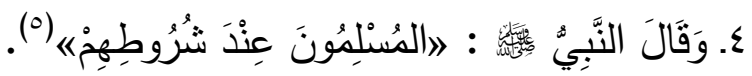

وجه الالالة: دلت هذه الأحاديث وغيرها على المراد من ناحيتين:

ا. وجوب الوفاء بالعهود والثروط والمواثيق، والنهي عن الغدر ونقض العهد،

ولو كان الأصل فيها الحظر لما أمر بها وذم من نقضها.

(1) الثرط الجعلي حكمه وأثثر في عقد الزواج دراسة مقارنة د/ خالد محمد

$$
\text { صالح/ V V إبدون. }
$$

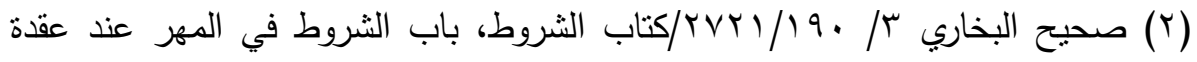
النكاح.

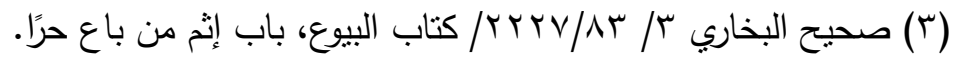

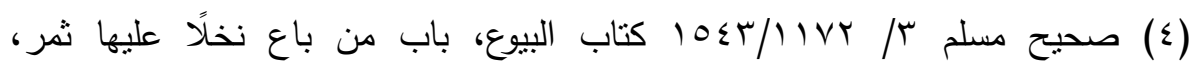

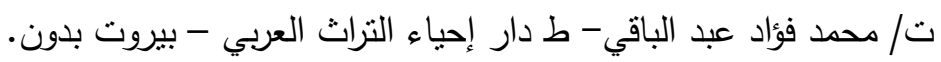

(0) صحيح البخاري س// ra / بدون رقم/كتاب الإجارة، باب أجرة السمسرة. 
r. أن العقود والثروط من الأفعال والأصل فيها الإباحة، فيستحب هذا الأصل إلى أن يدل دليل على التحريم (').

الراجح:

بالنظر في الأدلة السابقة من حيث قوتها ووضوح دلالتها على المراد،

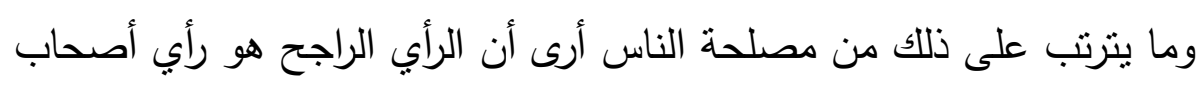

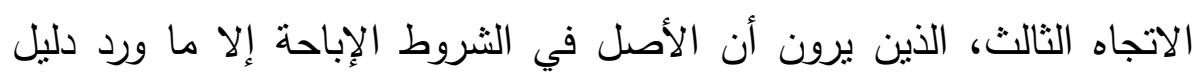

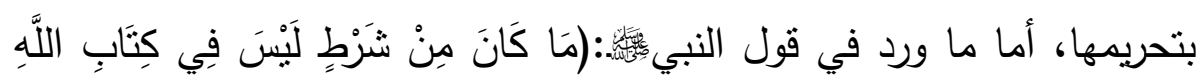

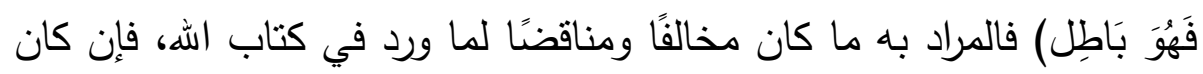

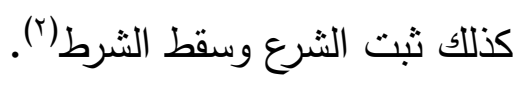

* $\quad * \quad * \quad * \quad * \quad *$

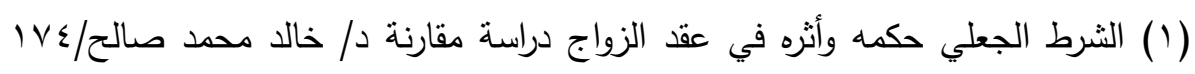
بتصرف. (ץ) المرجع السابق. 


\section{المبحث الثــاني}

أقسام الشرط عند الصنفية والجمهور

ويتضمن ثلاثة مطالب:

المطلب الأول: أقسام الثرط عند الحنفية.

الامطلب الثاني: أقسام الثرط عند الجمهور.

الاملب الثالث: أقسام الشرط الجعلي.

\section{الإطلب الأول : أقنسام الشرط عند المنفية}

بعد البحث والتتقيب في كتب الحنفية وجدت أن لهم تقسيماتٍ متعددةٍ

باعتباراتٍ مختلفةٍ ومن ذلك ما يلي:

التقسيم الأول: تقسيمهم لالشرط هن حيث هصدره أو هن حيث وضعه:

أجد أنهم قسموه إلى خمسة أقسام: حقيقيٌ وجعليٌ للشرع وعقليٌ

وعاديٌّ ولغويٌ:

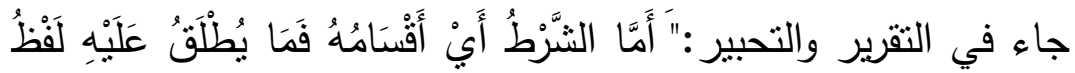

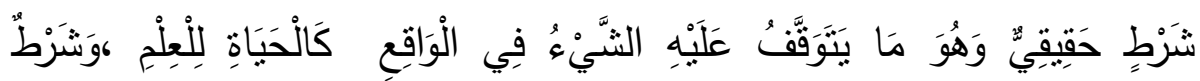

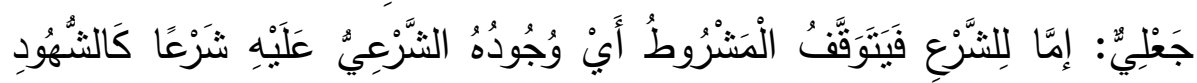

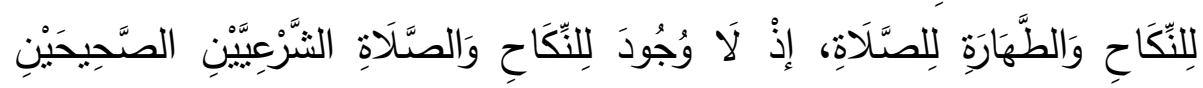

بِدُونِهِهَا" (1)

وجاء في قواطع الأدلة: " وأقسامه ثلاثة لأن عدم المشروط عند عدم

الشرط إن كان منشأه الثرع فهو شرط شرعي وإن كان منشأه العقل فهو شرط عقلي وإن كان منشأه العادة فهو شرط عادي ،وأضاف بعضهم نوعاً رابعاً وهو الشرط اللغوي وهو ما نتج عن دلالة اللغة(؟).

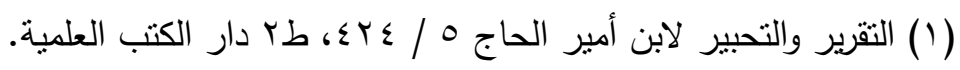
(ץ) قواطع الأدلة في الأصول للسمعاني / / ل . . 1، طادار الكتب العلمية، بيروت، لبنان. 
وتبعه على ذلك صاحب تيسير علم أصول الفقه(').

\section{ومهنى هذا أن الشرط ينقسم إلى:}

ا. الحقيقي: وهو ما ينوقف عليه وجود المشروط حقيقةً، كتوقف العلم

$$
\text { على الحياة. }
$$

r. جعليّ للشرع: وهو ما يتوقف عليه وجود المشروط شرعًا كالثشهود للنكاح،

والطهارة للصلاة.

r. عقليّ: وهو ما كان منشؤه العقل.

ع. عادي": وهو ما كان منشؤه العادة كوقوع الطلاق عند دخول الدار . ه. لغويٌّ: وهو ما كان مصدره اللغة.

\section{التقسيم الثاني: تقسيم الشرط باعتبار وجود حكمٍٍ له وعدم وجود حكمٍ: وذلك} على خمسة أقسام: محضٌ، وله حكم العلل، وما له حكم الأسباب،

$$
\text { وشرط اسمٍ لا حكم، وشرطٌ بمعنى العلامة. }
$$

جاء في كثف الأسرار :" وهو خمسة أقسام : شرط محض، وشرط لهن له حكم العلل، وشرط له حكم الأسباب، وشرط اسما لا حكما فكان مجازا في الباب، وشرط هو بمعنى العلامة الخالصة ".(r)ووافقه في ذلك شمس الأئمة

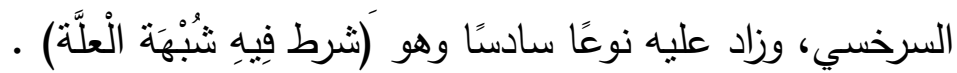

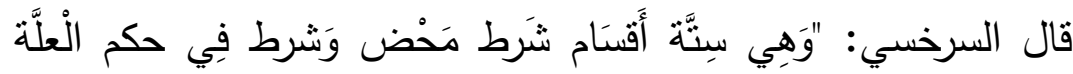

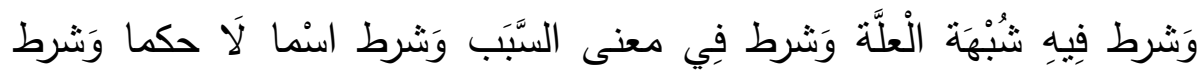

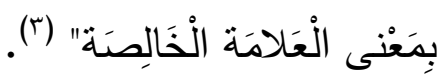

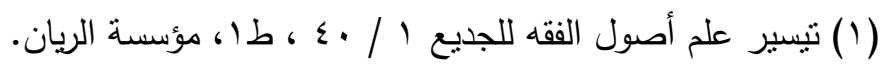

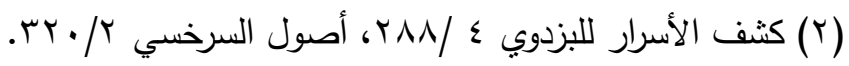

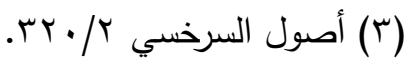




\section{وبيان هذه الأتسام كما يلي:}

ا. أما الثرط المحض: وهو ما بمتتع به وجود العلة فإذا وجد الثرط وجدت العلة، نحو إن دخلت الدار فأنت طالق.

r. وأما الثرط الذي هو في حكم العلل: فإن كل شرط لم بعارضهه علةٌ صلح أن أن يكون علةً يضاف إليه الحكم ومتى عارضه علةٌ لم يصلح علةً، مثاله ما قالوا في شهود الثرط واليمين إذا رجعوا بعد الحكم إن الضمان بطريق التعدي فلم يجعل الثرط علةً وإذا رجع شهود الثرط وحدهم يجب أن يضمنوا لما قلنا فأما شهود الإحصان إذا رجعوا فلا يضمنون بحالٍ عند الحنفية خلافًا لزفر. رحمه الله ـ لأن الإحصان لا يتعلق به وجوبٌ وإلا فلا يضمنون وجود.

ب. وأما الثرط الذي له حكم الأسباب فأن يعترض عليه فعل مختارٍ غير منسوبٍ إليه وأن يكون سابقًا عليه وذلك منل رجلٍ حل قيد عبدٍ حتى لهِ أبق لم يضمن قيمته باتفاق أصحابنا لأن المانع من الإباق هو القيد فكان حله إزالةٌ للمانع فكان شرطاً في الحقيقة إلا أنه لما سبق الإباق الإن الذي هو علة التلف نزل منزلة الأسباب فالسبب مما يتقدم والثرط

مما يتأخر .

ع. وأما الذي هو شرطٌ اسمًا لا حكمًا فإن كل حكمٍ تعلقٍ بشرطين فإن أولهما شرطٌ اسمًا لا حكمًا؛ لأن حكم الثرط أن يضاف الوجود إلبه وذللك مضافٌ إلى آخرهما فلم يكن الأول شرطًا، بل اسمًا ولهذا قلنا فيمن قال لامرأنه: إن دخلت هذه الدار وهذه الدار فأنت طالق ثم أبانها ثم بـ دخلت إحداهما ثم نكحها ثم دخلت الثانية أنها تطلق. ه. وأما الثرط الذي هو علامةٌ فكالإحصان في باب الزنا، وإنما قلنا إنه علامةٌ؛ لأن حكم الشرط أن يمنع انعقاد العلة إلى أن يوجد الثرط وهذا 
لا يكون في الزنا بحالٍ؛ لأن الزنا إذا وجد لم يتوقف حكمه على

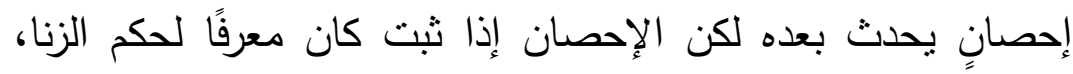

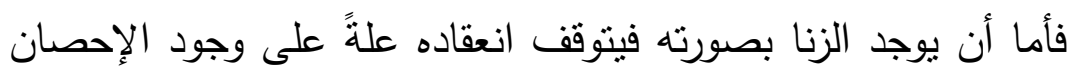
فلا يثبت أنه علامةٌ وليس بشرطٍ فلم يصلح علةً للوجود ولا للوجوب. (')

* $\quad * \quad * \quad * \quad * \quad *$

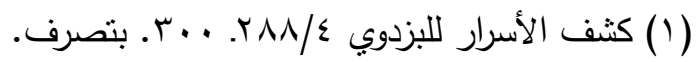




\section{الاطلب الثاني : أقسام الشرط عند الجمهور}

قسم الجمهور الثرط باعتبار منشئه ومصدره إلى أربعة أقساحٍ: شرطٌ

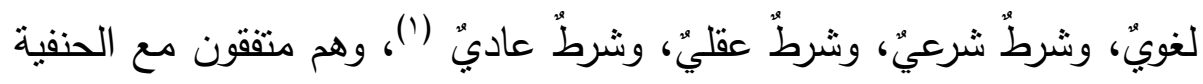
في هذا التقسيم، لكن زاد الحنفية عليها الثرط الحقيقي • جاء في البحر المحيط:" وهو ـ أبي الثرط ـ عَلَى أَرْبَعَةِة أَقَمَامٍ: أولها

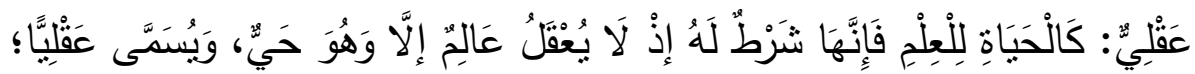

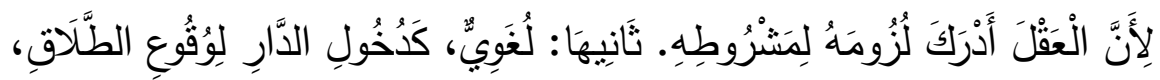

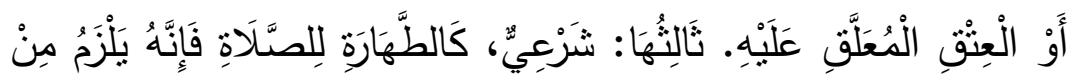

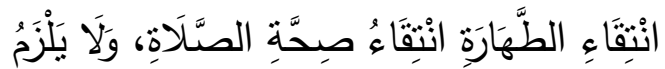

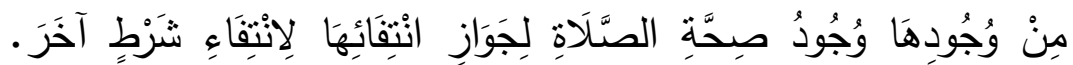

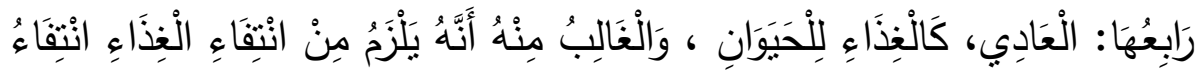

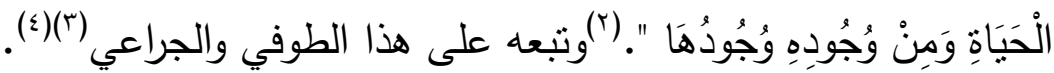
* * * * * * * *

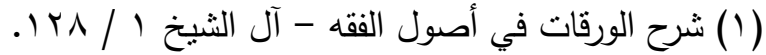

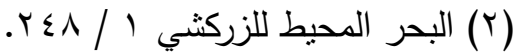

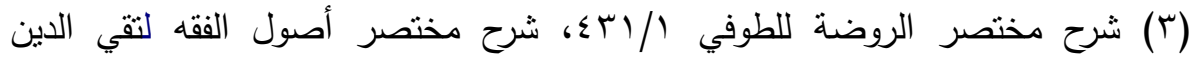

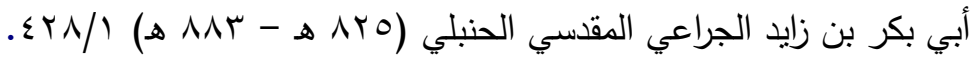

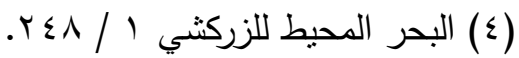


المطلب الثالث : أنواع وأقسام الشروط الجعلية عند كلٍ هن الحنفية والجمهور

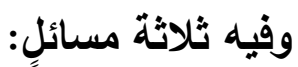

المسألة الأولى: أنواع الثروط مئل: الجعلية.

المسألة الثانية: أقسام الشروط الجعلية من حيث اعتبارها شرعًا وعدم أشئه اعتبارها عند الحنفية والجمهور.

المسألة الثالثة: أقسام الثروط الجعلية باعتبار أثرها على التصرفات واندات

وفيها ثلاثة فروعٍ:

الفرع الأول: الثرط الصحيح.

الفرع الثاني: الثرط الباطل.

الفرع الثالث: الثرط الفاسد.

\section{المسألة الأولى : أنواع الشروط الجعلية.}

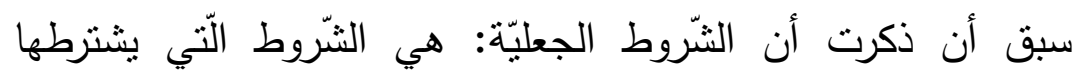

المكلّف في العقود وغيرها، كالطّلاق والعتاق والوصيّة.

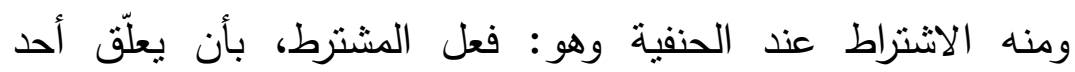

تصرّفاته، أو يقيّدها بالثّرط، فمعنى الاثتراط لا يتحقّق إلاّ في الثنرّط الجعليّ.

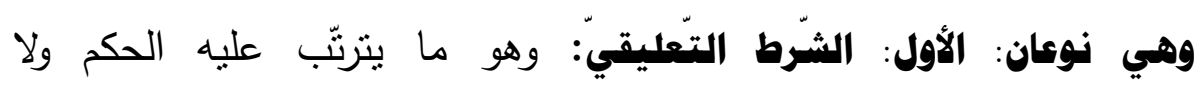

$$
\text { يتوقّت عليه ('). }
$$

وقيل: هو ما يعمل في أصل التصرف في العقد فيؤخر انعقاده وأثثر

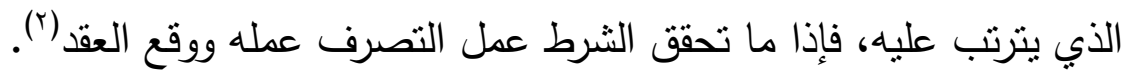

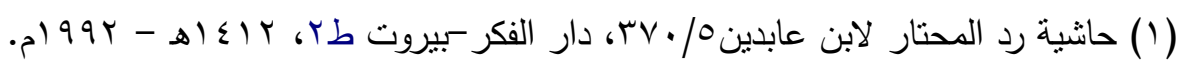

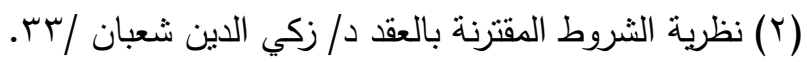


وهو يصاغ عادة بأحد الأدوات الثرطية التي تربط بين فعليه نحو إن

$$
\text { وإذا ومنى وكلما. }
$$

مثاله: الطّّلاق المعلّق على دخول الدّار، كما إذا قال لها: إن دخلت الدّار فأنت طالقُ، فإنّ الطّلاق مرثّبٌ على دخولها الدّار، فلا يلزم من انتفاء

الدّخول انتفاء الطّلاق، بل قد يقع الطّلاق بسببٍ آخرٍ. (') ومثاله في عقد الإجارة: لو قال أجرتك هذه الدار إن رضي أبي في مدة كذا فقد تعلق وقوع الإجارة وانعقادها على رضا الأب فإذا وجد الرضا تحققت الإجارة.

والندوع الثاني: الشّرط التقيسيدي: وهو التزام أمرٍ لم يوجد في أمرٍ وجد بصيغةٍ مخصوصةٍ (r)

وقيل هو: ما لا يعمل في أصل التصرف بل يعمل في أثزه وحكمه

الذي ينرتب عليه بعد أن كان مطلقًا أو ناجزًا(). وهو يصاغ عادة بعبارات منّ: (على أن، أو على شرط أن،

$$
\text { أو شرط أن). }
$$

مثاله في عقد الإجارة: لو قال أجرتك هذه الدار على أن أسكنها ستة أثهر مثثلً وقبل الآخر ذلك فالعقد تحقق مقارنًا بالثرط فيعمل العقد والشرط جميعًا، فالعقد يحل الانتفاع بالسكن للمستأجر وحق الانتفاع بالسكن للماللك مدة

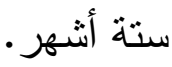

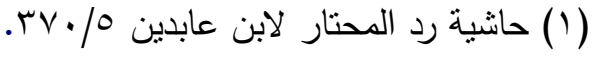

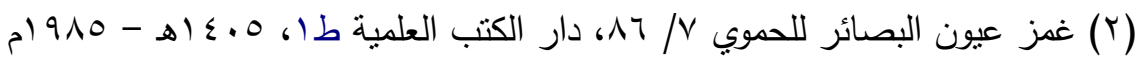

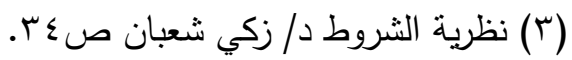




\section{ويشترط لصحة الشرط التعليقي أهران:}

ا. أن يتصل الثرط بالجزاء دون وجود فاصلٍ بينهما.

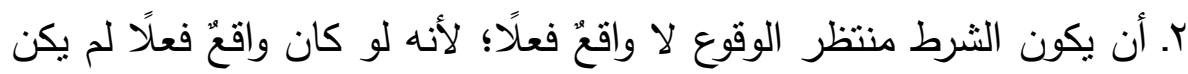

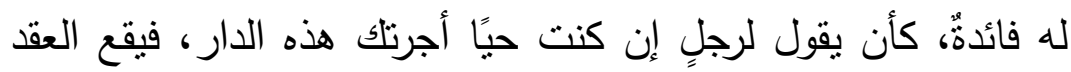

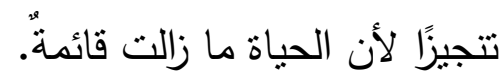

r. ألا يكون الثرط مستحيل الوقوع؛ لأنه لو كان مستحيلًا وقع الثرط باطلًا،

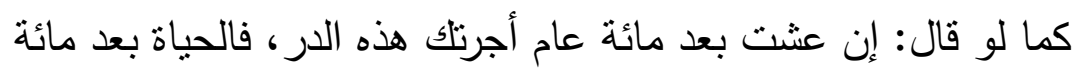
عام نادرةٌ، وهذا شرطٌ مستحيلٌ فوقع باطلًا.

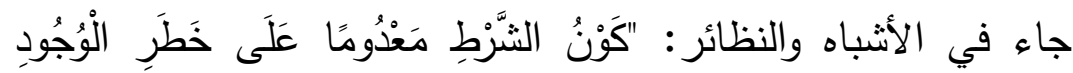

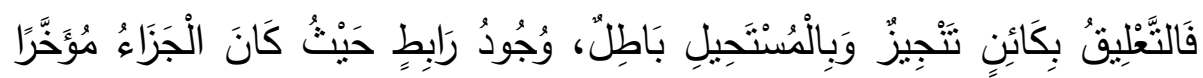

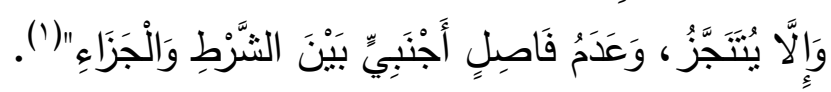
ويشترط لصحة الشرط التقييدي أهران:

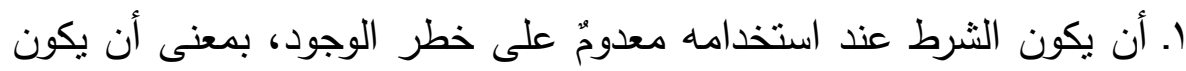

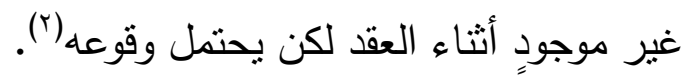

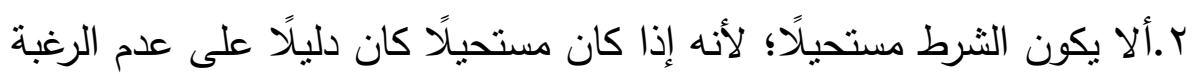
في إتمام التصرف (r). الفرق بين الشرط المعلق والشرط المقرفيد (هن حيث الأثر):

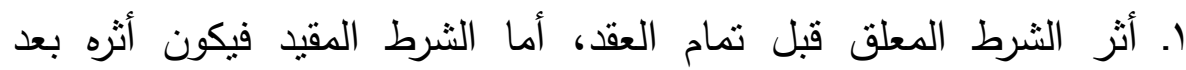

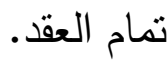

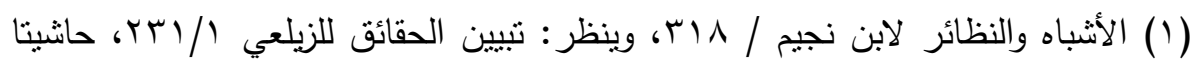

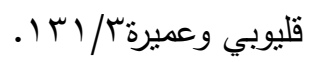

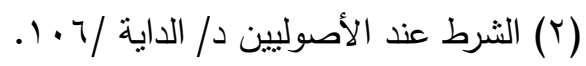

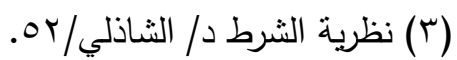


r. الثرط المقيد بعمل في أثز العقد وحكمه لا في أصله('). مثال ذللك في الثرط المعلق: قول القائل أذهب للدرس إذا طلع النهار، فعلق الذهاب للارس بطلوع النهار . ومثاله في الثرط المقيد: كقول القائل أجرتك هذه الدار على أن أسكنها ثناثة أثنهرٍ فقيد عقد الإجارة بشرط أن يسكنها ثناثة أثهرٍ . فالعقد صحيحُ في أصله، لكن ثقيد أثزه وحكمه بهذا الثرط. نقل الحموي عن الزركثي الفرق بين التعليقي والتقييدي:"أن التعليقي: ترتيب ما لم يوجد على أمرٍ يوجد بأن أو إحدى أخواتها، والتقييدي: التزام أمرٍ لم يوجد في أمرٍ قد وجد بصيغةٍ مخصوصةٍ" (؟). فوصف المعلق بأنه ترتيب والترتيب يكون قبل تمام العقد، ووصف التقييد بأنه التزامُ، وهو يكون بعد تمام العقد وفي حكمه وأثزه. المسألة الثانية: أقسام الشروط البعملية هن هيث اعتبارها شرعاً وهذه الثّروط الجعليّة لها عدة أقسام ترجع كلها إلى اعتبارين: الأول:

$$
\text { من حيث اعتبارها شرعًا وعدم اعتبارها }
$$

وهي بهذا الاعتبار تنقسم إلى ثلاثة أقسام: القسم الأول: شرطٌ لا ينافي الثّرع: بل هو مكمّل للشّروط وذللك كما لو اشترط المقرض على المقترض رهناً أو كفيلاً. الثاني: شرطٌ غير ملائح للمشروط: بل هو مناف لمقتضاه، كما لو رهن اشترط الزّوج في عقد الزّواج ألا ينفق على الزّوجة.

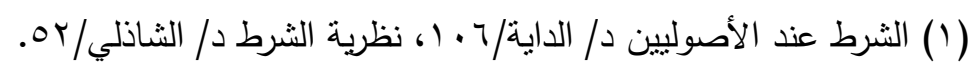

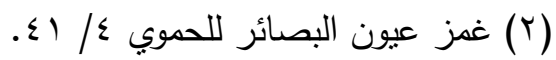


القسم الثالث: شرطٌٌ لا ينافي الثّرع ما شرط فيه، وفيه مصلحةٌ لأحد العاقدين

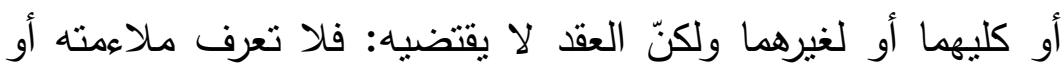
عدم ملاءمته للعقد وذلك كما لو باع منزلاً على أن بسكنه البائع مثناً

$$
\text { فترةً معلومةً أو يسكنه فلان الأجنبيّ. }
$$

المسألة الثالثة : أقسام الشروط الجعلية باعتبار أثرها على التصرفات

$$
\text { وهذه المسألة موطن خلافٍ بين الحنفية والجمهور : }
$$

فالجمهور: قسموا الثروط الجعلية باعتبار أثزها على التصرفات إلى قسمين:

$$
\text { صحيحُ وباطلّ. }
$$

والحنفية: قسموها إلى صحيحٍ وباطلٍ وفاسدٍ، فزاد الحنفية على الجمهور الفاسد.

وقد جعلت كل قسم من هذه الأقسام فرعًا وذكرت فيه تعريفًا لله مع ذكر

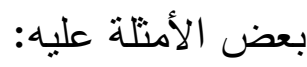

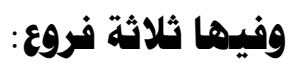
الفرع الأول: الشرط الصحيح. الفرع الثاني: الشرط الباطل. الفرع الثالث: الثرط الفاسد.

\section{الفرع الأول : الشرط الصحيح}

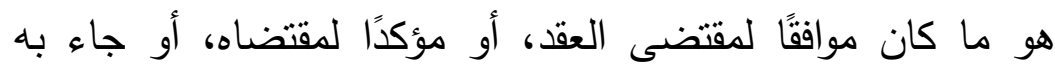

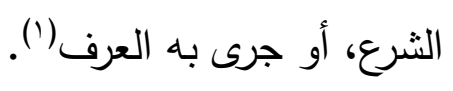

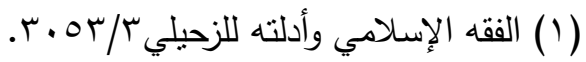


وهو على أنواعٍ: ا. ما يقتضيه العقد . r. مؤكدٌ لمقتضى العقد. r. ما ورد به

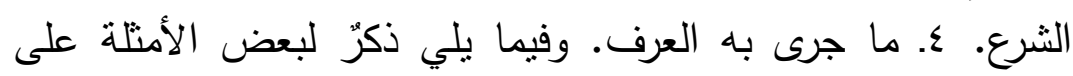

$$
\text { كل نوعٍ '(1) }
$$

\section{اـ هثال الشرط الذي يقتضيه العقد:}

_ـ اثتراط البائع تسليم الثمن أو حبس المبيع حتى أداء جميع الثمن. _ واشتراط المشتري تسليم المبيع، أو تملكه.

- واشتراط الزوجة على زوجها أن ينفق عليها، واشتراطه عليها تسليم نفسها إذا

$$
\text { قبضت مهرها. }
$$

فهذه شروطٌٌ تبين مقتضى العقد أو توافق مقتضاه؛ لأن مضمونها واجب التحقق شرعاً، حتى ولو لم يشترطها أحد العاقدين؛ لأن ثبوت الملك تلك والتسليم والتسلم وحبس المبيع من مقتضى المعاوضات، والإنفاق على الزوجة

وزفافها من مقتضى الزواج.(r)

\section{r ه هثال الشرط المؤكد المتضى العقد:}

- اشتراط البائع تقديم كفيل أو رهن معينين بالثمن عن تأجيله للمستقبل، فإن الكفالة والرهن استيثاقُ بالثمن، فيلائم البيع ويؤيد التسليم. ومنتل اشتراط كون والد الزوج كفيلاً بالمهر والنفقة.

rـ والشرط الذي ورد به الشرع: مثل اشتراط الخيار أو الأجل لأحد

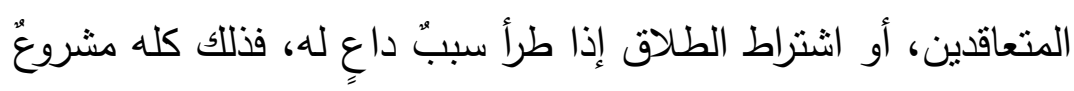

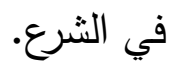

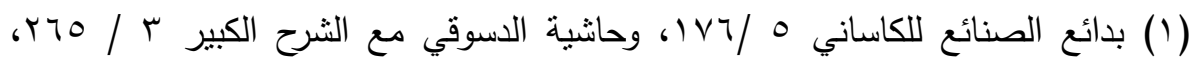

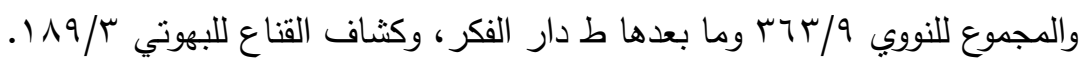

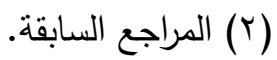


عـ والشرط الذي جرى به العرف: مثل اثتراط المشتري على البائع التعها

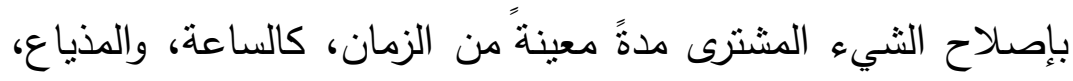

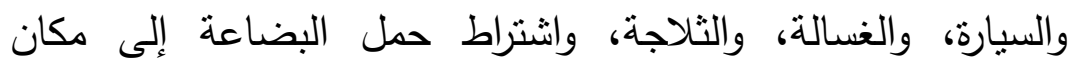

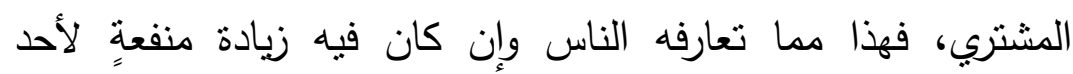
العاقدين، فجاز استحساناً.

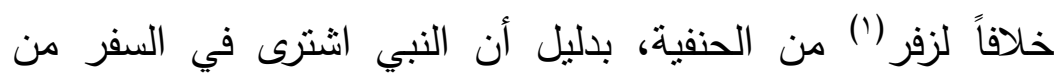
جابر بن عبد الله بعيراً، وشرط لجابر ركوبه وحملانه عليه إلى المدينة.

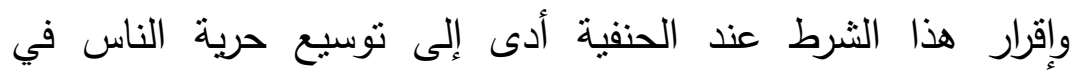

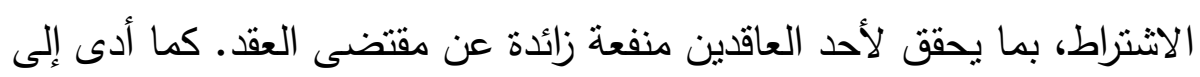

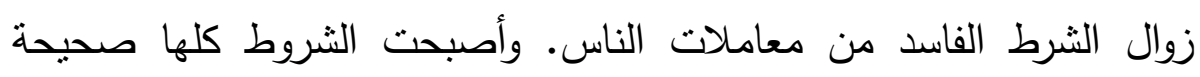
بالعرف إلا إذا كانت مصادمة لنص تشريعي، أو منافية لمبادئ الثريعة.

\section{الفرع الثاني : الشرط الباطل}

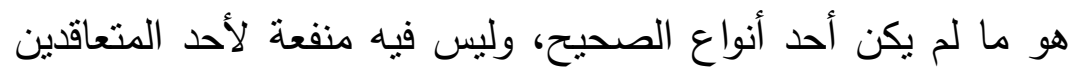
ولا لغيرهما، وإنما هو ما كان فيه ضررٌ لأحد العاقدين.

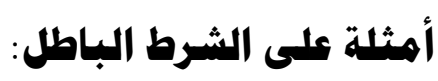

كاشتراط بائع البضاعة على المشتري ألا يبيعها أو لا يهريها لأحدٍ،

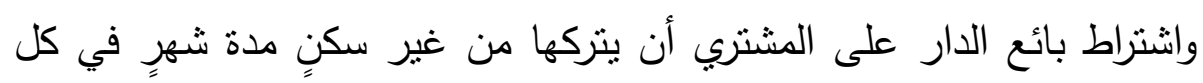

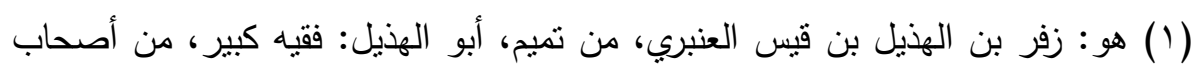

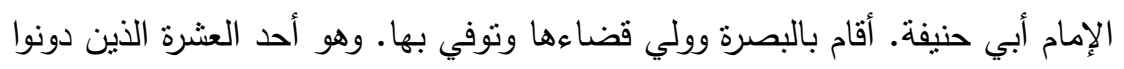

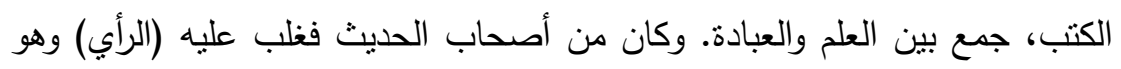

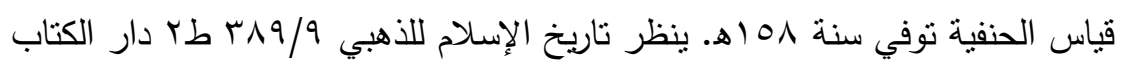

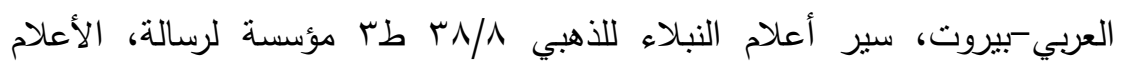

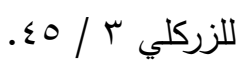


سنةٍ مثلاً، واشتراط بائع سيارةٍ ألا يُركب المشتري فلاناً فيها أو يضعها في

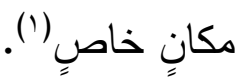
فالعقد صحيحُ حينئذ، والثرط لغوٌ باطلٌ لا قيمة له، سواء في عقود المعاوضات، أم في العقود الأخرى كالزواج والكفالة والهية(؟). الفرع الثالث : الشرط الفاسد

هو: ما كان شرطًا لا بقتضيه العقد ولا يلائمه ولم يرد به الثرع ولا العرف وكان لأحد المتعاقدين فيه منفعة.

أمثلة على الشرط الفاسد:

كثراء حنطةٍ على أن يطحنها البائع، أو قماشُ على أن يخيطه البائع قميصاً مثناً، أو شراء بضاعةٍ على أن يتركها في ملك البائع شهراً، أو بيع دارٍ على أن يسكنها البائع شهراً أو أكثر، أو شراء أرضٍ على أن يزرعها البائع

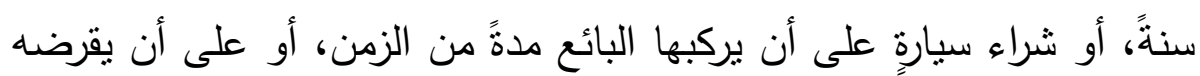

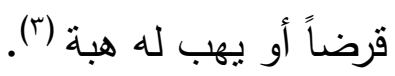
ويختلف أثز الثرط الفاسد على العقود بحسب نوع العقد.

(1) حلية العلماء في معرفة مذاهب الفقهاء لسيف الدين أبو بكر محمد بن أحمد الثانثي

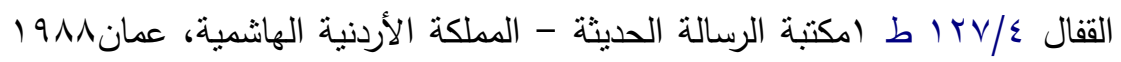

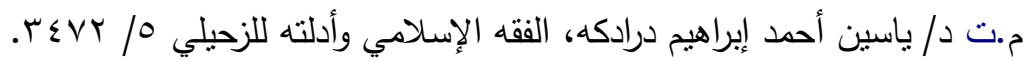

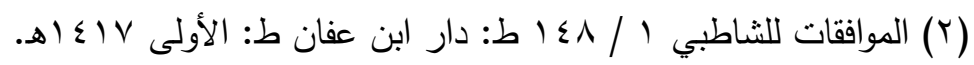

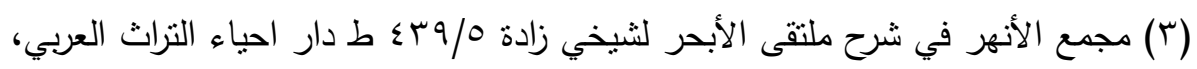

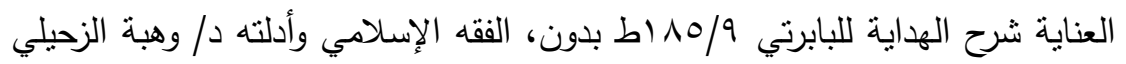
.07 . / 
والقاعدة المقررة في ذلك هي: أن الثرط الفاسد في عقود المعاوضات المالية

$$
\text { يفسدها، وفي غيرها لا يؤثر عليها" (') }
$$

فالثرط الفاسد في المعاوضات المالية كالبيع والإجارة والقسمة

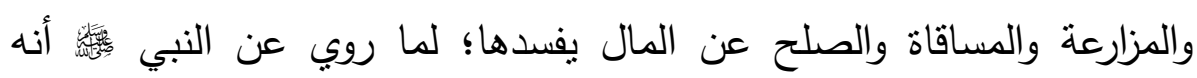

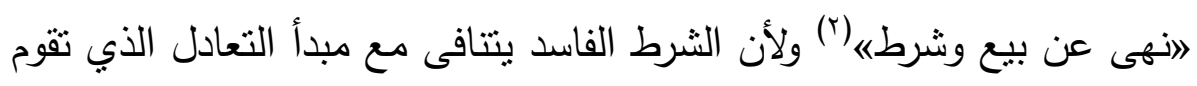

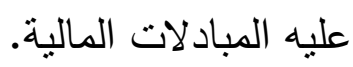

وأما العقود الأخرى غير المبادلات المالية كالتبرعات (هبة أو إعارة) والتوثيقات (كفالة أو حوالة أو رهن)، والزواج والطلاق، والإطلاقات كالوكالة،

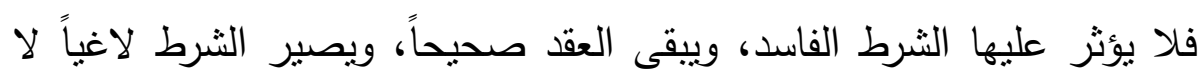

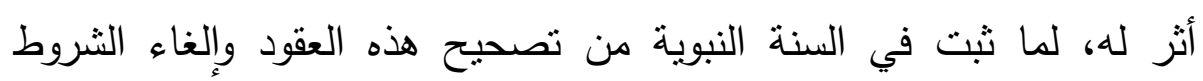

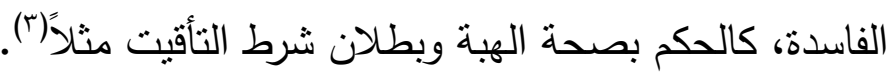

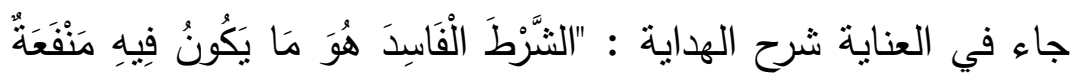

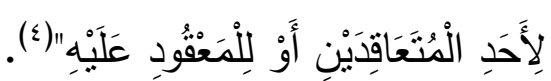
ومن خلال تعريف كلًا من الثرط الباطل والفاسد ألاحظ أن الفرق

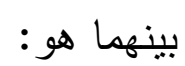
أن الباطل ما نرتب عليه ضرر على أحد العاقدين أو المعقود عليه، فمن باب دفع الضرر عن العاقدين بطل هذا الثرط.

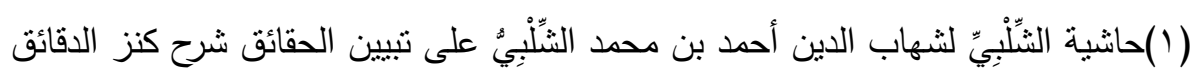

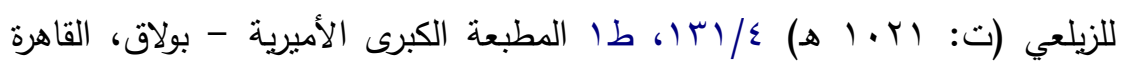

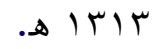

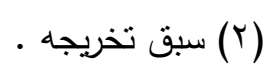

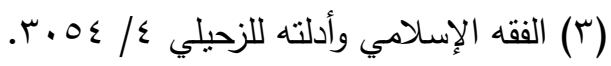

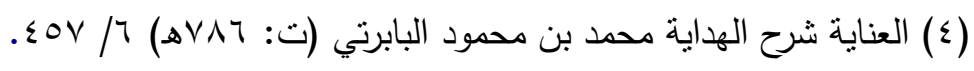


أما الفاسد فليس فيه ضرر على أحد العاقدين، بل فيه منفعة لأحدها لكنه لا يقتضيه العقد ولا يلائمه ولم يرد به الثرع ولا العرف، فبناء على مخالفته لما جاء به الثرع كان فاسدًا وهو يؤثز على بعض العقود دون غيرها

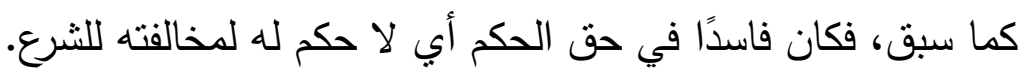

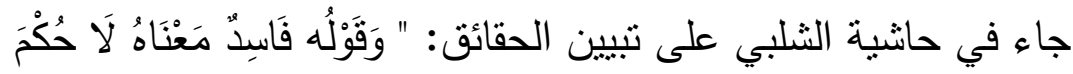
لَلهُ فَكَانَ فَاسِدًا فِي حَقِّ الْحُكْم" (1). وقد جاء في الموسوعة الكوينية خلاصة أقوال العلماء في أقسام الثرط من حيث الصحة والبطلان والفساد، وهذا نص ما ورد فيها:

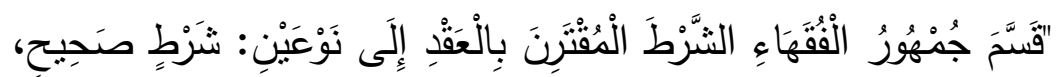

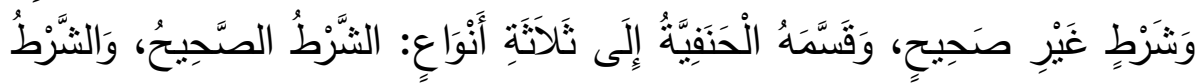

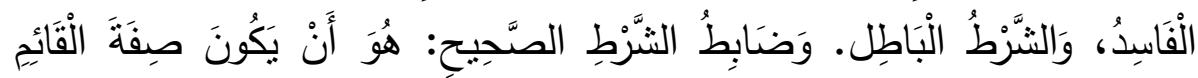

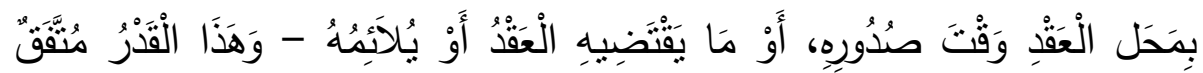

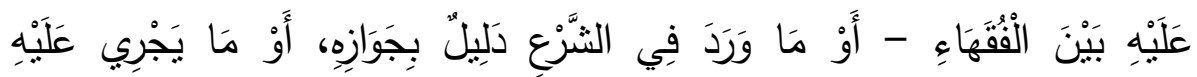

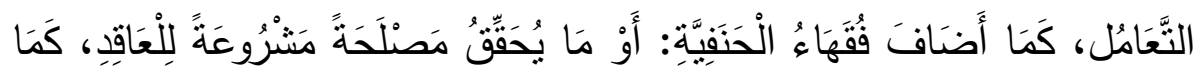

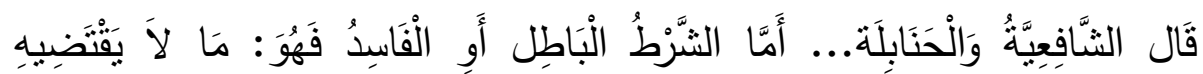

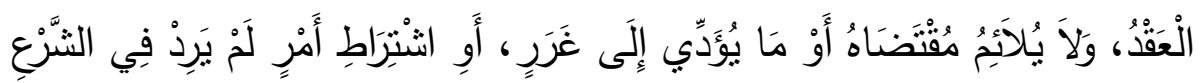

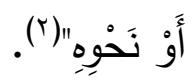

* $\quad * \quad * \quad * \quad * \quad *$

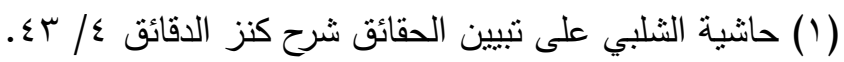

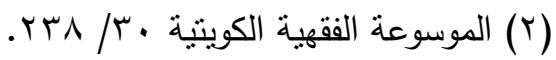




\section{المبحث الثالث}

أهثلة تطبيقية هماصرة للشروط الجعلية على باب الإجارة

وفيه خمسة مطالب:

الاملب الأول: الإيجار المنتهي بالتمليك.

الاطلب الثاني: شرط دفع مقدم للإيجار.

المطلب الثالث: الشرط الجزائي في عقود المعاوضات.

الاملب الرابع: الإيجار المؤيد المعروف بالإيجار القديم.

المطلب الخاهس : حكم الثتراط صيانة العين المؤجرة.

\section{المطاب الأول : الإيجار المنتهي بالتهميك}

سبق أن ذكرت أن الشروط الجعلية على نوعين: منها ما هو تعليقيٌ

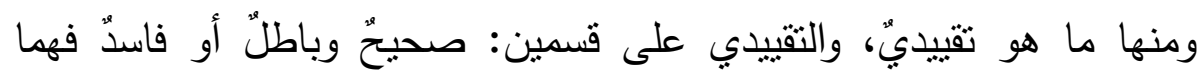
منرادفان عند الجمهور ، وجعل الحنفية الفاسد قسمًا مستقلًا. وهذه الثروط من حيث اعتبارها شرعًا وعدم اعتبارها على ثلاثة أنواعٍ: شرطٌٌ لا ينافي الثّرع، وشرطٌ غير ملائحٍ للمشروط بل هو منافٍ

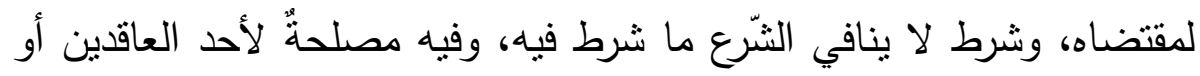
كليهما أو لغيرهما ولكنّ العقد لا يقتضيه. وفي هذا المبحث سأتناول بعضًا من الأمتلة التطبيقية الواقعية وأطبقها على هذه الثروط: وهن هذه الأهثلة: الإيجار المنتهي بالتمليك، وهو صورة من صور الإيجار المعاصر للعقارات والسيارات.

وصورته أنه: عقد إيجار يذكر فيه شرطٌ وهو: أنه بعد انتهاء دفع أقساط

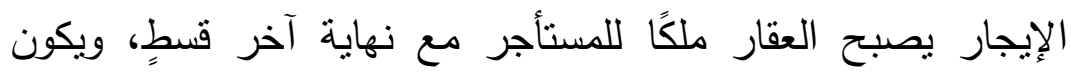
الإيجار أغلى من المعتاد لمنل هذه العين المؤجرة، وهو بذلك عقد الته 
إيجارٍ ينتهي إلى بيعِ، وفيه أيضا شرط أن المستأجر إن لم يستكمل

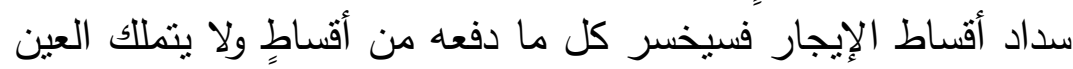
المؤجرة. وهو عقدّ له عدة صورٍ وما ذكرناه هو الصورة المعروفة لدى الاقتصاديين. فهذا العقد به صورةٌ من صور الثروط الجعلية الدذكورة بعقد الإيجار بالتراضي بين الطرفين بتملك المستأجر للعين المؤجرة بنهاية مدة الإيجار .

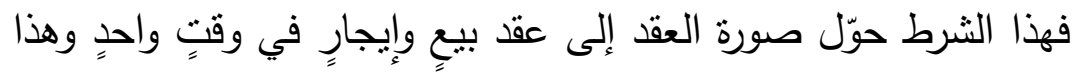

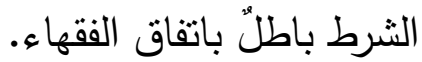

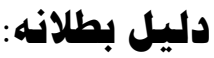

ما روي عن عمرو بن شُعيبٍٍ(') عن أبيه عن جده، قال: (نهى رسول اله

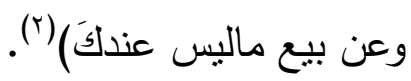

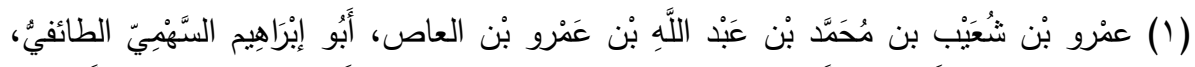

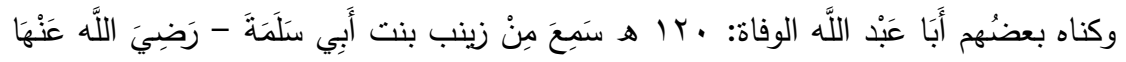

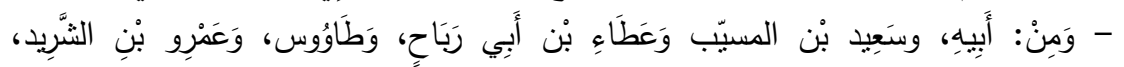

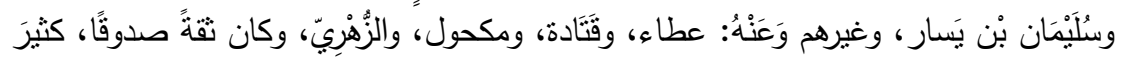

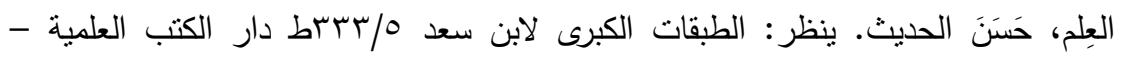

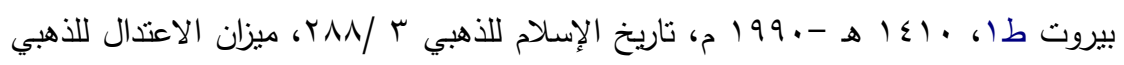

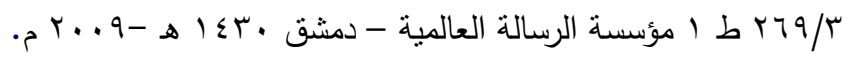

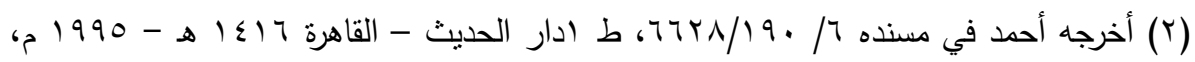

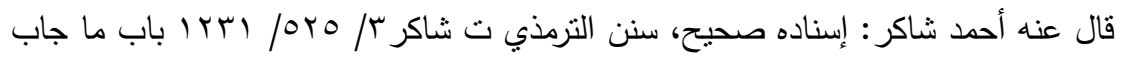

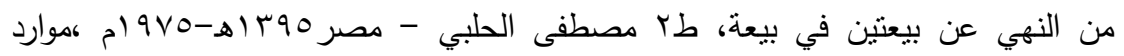

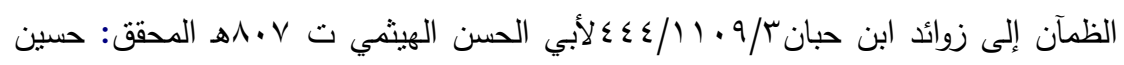

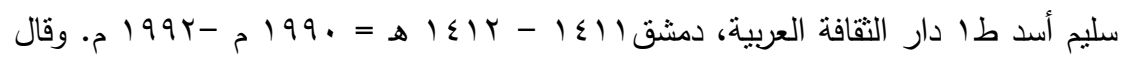

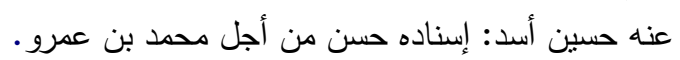




\section{وجه الدلالة هن هذا الحديث:}

النهي عن الجمع بين عقدين في عقدٍ واحدٍ، ومما يؤيد هذا ما ورد عن

الإمام الثافعي ـ رحمه اله ـ أنه قال عن معنى هذا الحديث:

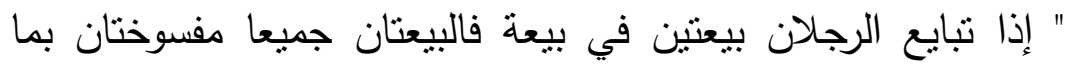

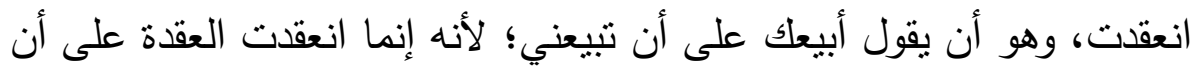

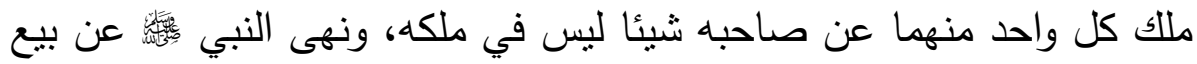

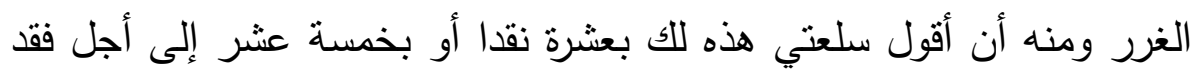

وجب عليه بأحد الثنين؛ لأن البيع لم ينعقد بشئ معلوم "( (1).

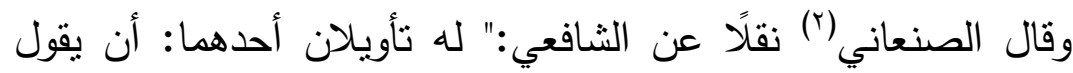

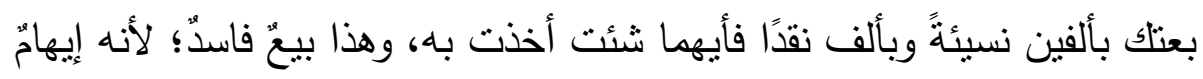
وتعليقُ. والثاني: أن يقول بعتلك عبدي على أن تبيعني فرسك انتهى. وعلة

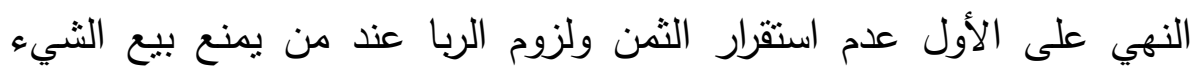

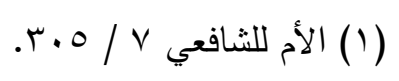

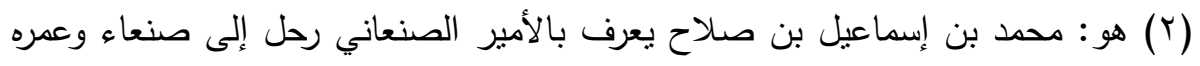

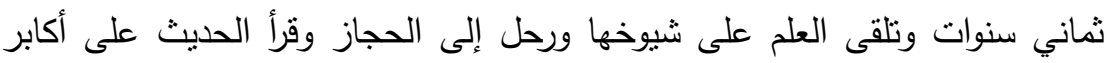

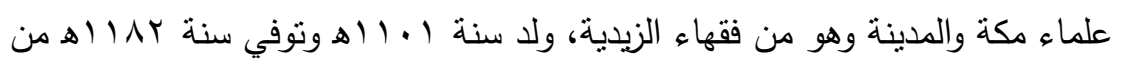

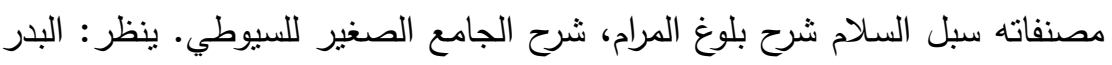

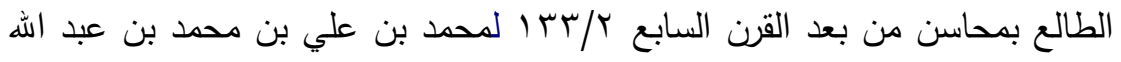

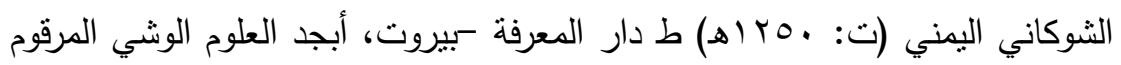

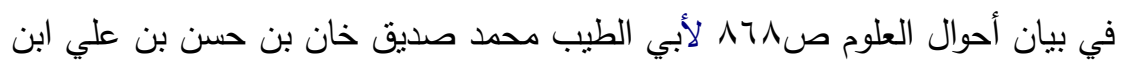

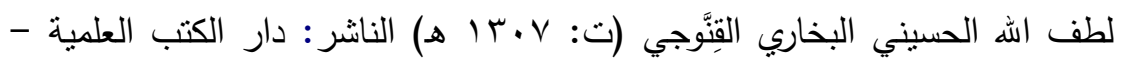

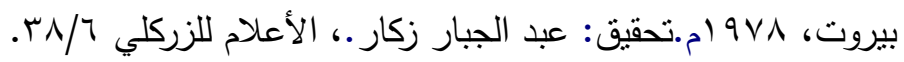


بأكثر من سعر يومه لأجل النساء. وعلة النهي على الثاني: تعليقه بشرطٍ

مستقبلٍ يجوز وقوعه وعدم وقوعه فلم بستقر الملك" (1).

وهو أيضا منهي: عنه لحدوث الغرر والضرر على ولى المستأجر إن عجز

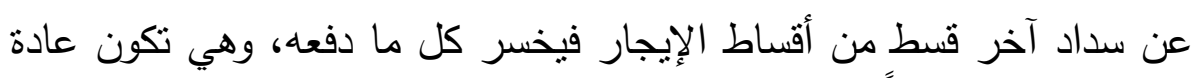

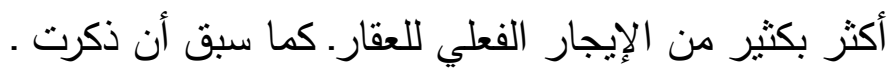

\section{الهذا جاءت فتوى هيئة كبار العلماء بتحريم هذه الصورة للآتي:}

أولاً: أنه جامعٌ بين عقدين على عينٍ واحدةٍ غير مستقرٍ على أحدهما، وهما مختلفان في الحكم متتافيان فيه.

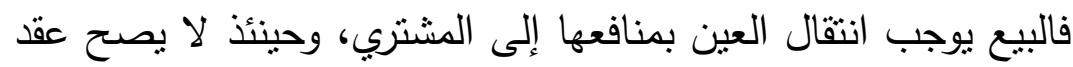

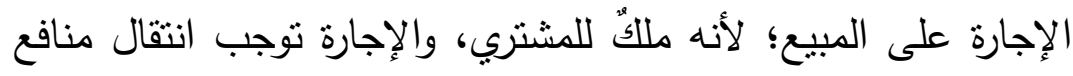
العين فقط إلى المستأجر . العانه

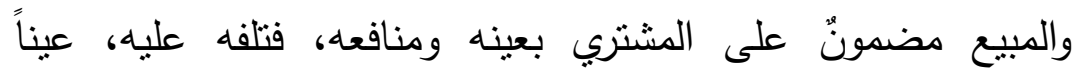

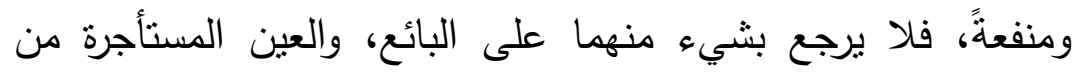

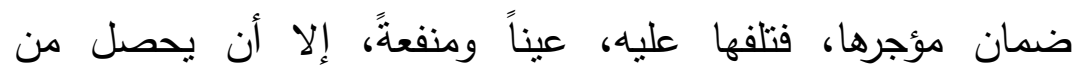
المستأجر تعد أو تفريط.

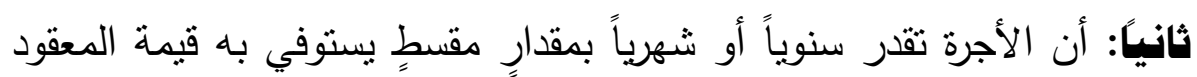

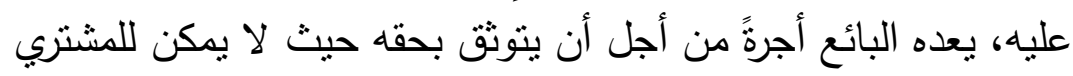

بيعه.

مثال" لذلك: إذا كانت قيمة العين التي وقع عليها العقد خمسين ألف ريباٍٍ

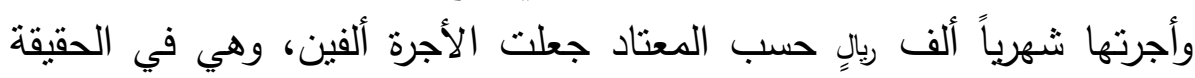

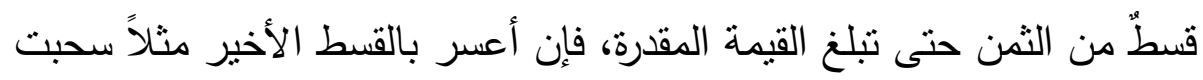

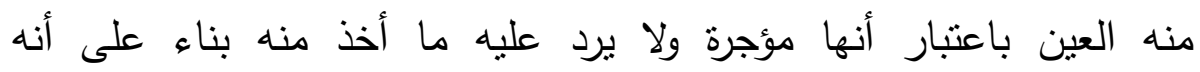
استوفي المنفعة.

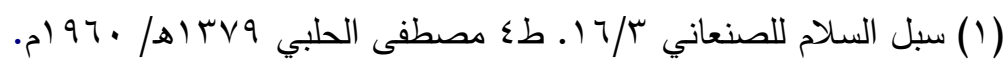


ولا يخفى ما في هذا من الظلم والإلجاء إلى الاستدانة لإيفاء القسط

الأخير ، ومضاعفة الإيجار (').

كما صدر قرار مجمع الفقه الإسلامي في دورته الثانية عشر بالرياض سنة اYY I هـ واضعًا ضوابط للصور الجائزة والغير جائزة في الإيجار المنتهي بالتمليك وذللك فيما يلي:

\section{ضوابط الإيجار المنتتهي بالتمبيك:}

أولاً: ضابط الصور الممنهوعة والجائرة ها يلي:

ا - ضابط المنع: أن يرد عقدان مختلفان في وقتٍ واحدٍ على عينٍ واحدةٍ في

$$
\text { زمنٍ واحدٍ. }
$$

ץ- ضابط الجواز : وجود عقدين منفصلين يستقل كل منهما عن الآخر زماناً، بحيث يكون إبرام عقد البيع بعد عقد الإجارة، أو وجود وعدٍ بالتمليك

في نهاية مدة الإجارة، والخيار يوازي الوعد في الأحكام.

وأن تكون الإجارة فعليةٌ وليست ساترةٌ للبيع.

r- أن يكون ضمان العين المؤجرة على المالك لا على المستأجر، وبذلك يتحمل المؤجر ما يلحق العين من التصرف الغير ناشيءٍ من تعد المستأجر ، أو تفريطه، ولا يلزم المستأجر بشيء إذا فاتئ المنفعة.

(1) الثرط الجزائي وأثره في العقود المعاصرة د/ محمد اليمني/ج اس وما بعدها، عقد الإجارة

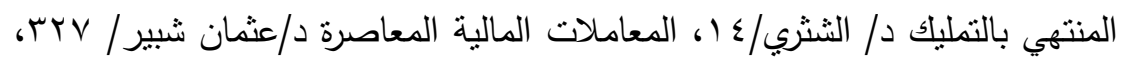

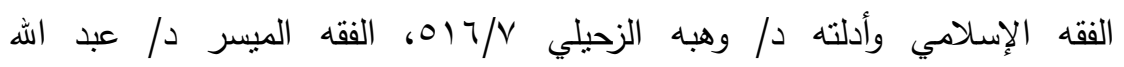

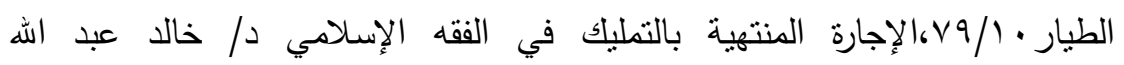

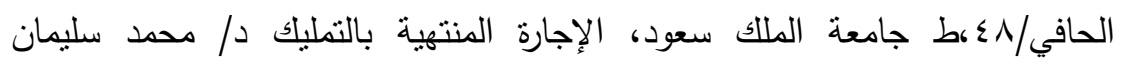

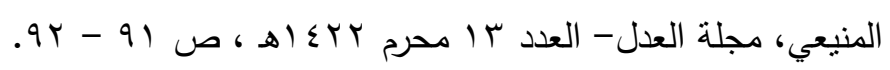


ع- إذا اشتمل العقد على تأمين العين المؤجرة فيجب أن يكون التأمين تعاونياً

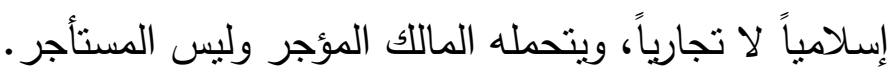

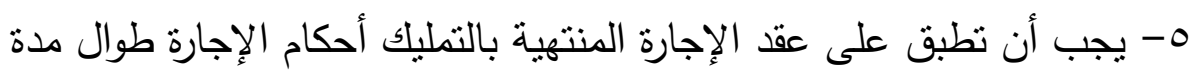
الإجارة، وأحكام البيع عند تملك العين.

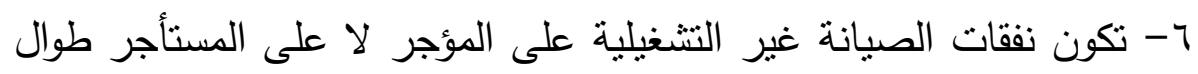

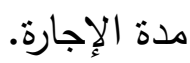

\section{ثانياً: هن صور العقد الممنوعة:}

1- عقد إجارٍ ينتهي بتملك العين المؤجرة مقابل ما دفعه المستأجر من أجرةٍ

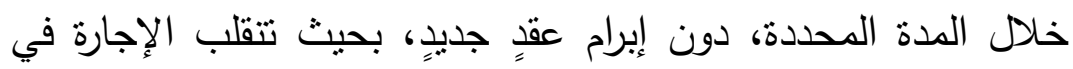
نهاية المدة بيعاً تلقائياً.

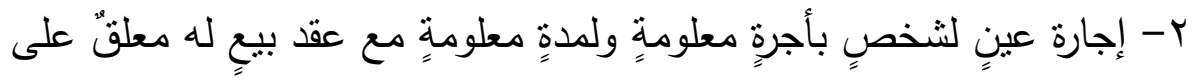

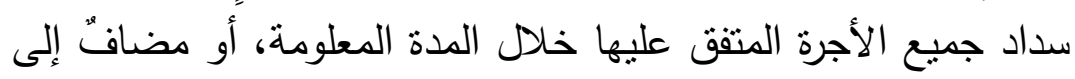
وقتٍ في المستقبل.

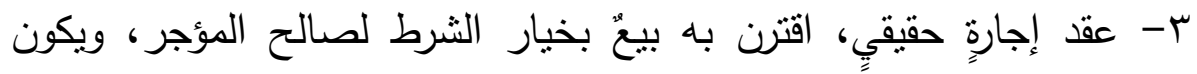

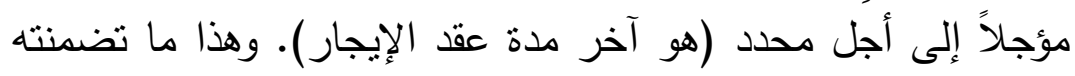

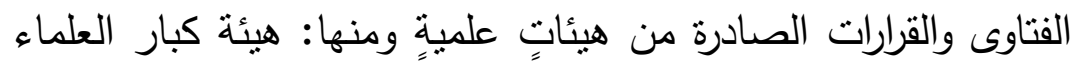

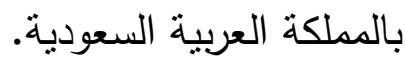

\section{ثالثًا: هن صور العقد الجائزة:}

1- عقد إجارٍ يمكن المستأجر من الانتفاع بالعين المؤجرة مقابل أجرة معلومة

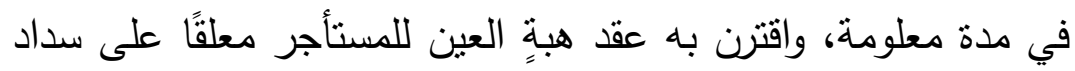

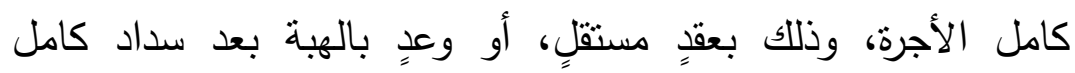

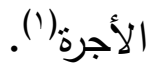

(1) قرار مجمع الفقه الإنلامي بجدة بالنسبة للهبة رقم (T///T) في دورته الثالثة. 
ץ- عقد إجارٍ مع إعطاء المالك الخيار للمستأجر بعد الانتهاء من وفاء جميع

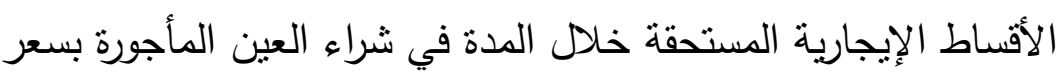

$$
\text { السوق عند انتهاء مدة الإجارة('). }
$$

r- عقد إجارٍ بمكن المستأجر من الانتفاع بالعين المؤجرة مقابل أجرةٍ معلومةٍة،

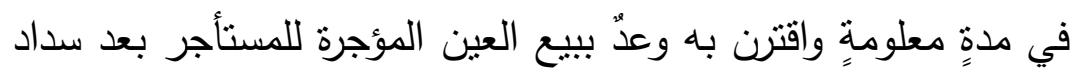
كامل الأجرة بثمنٍ يتفق عليه الطرفان.

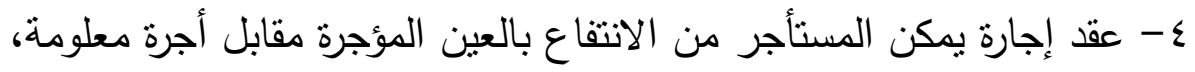

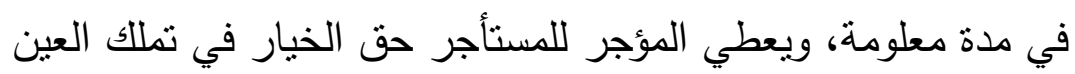

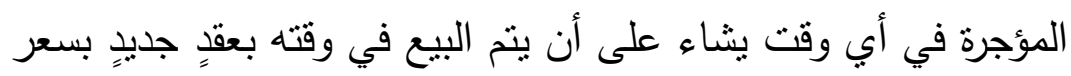
السوق. أو حسب الاتفاق في وقته. رابعا: هناك صورٌ من عقود التأجير المنتهي بالتمليك محل خلافٍ، وتحتاج

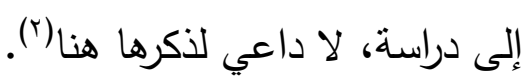

\section{المطاب الثاني : شرط دفع هقدم للإيجار}

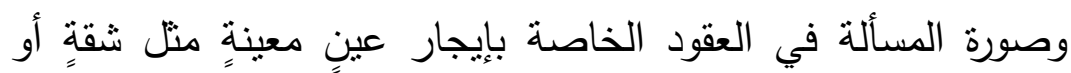

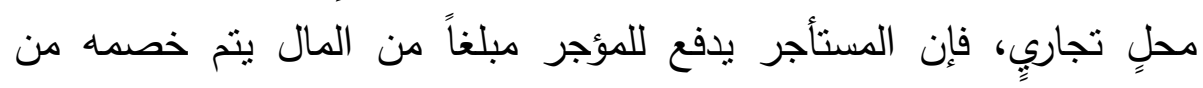

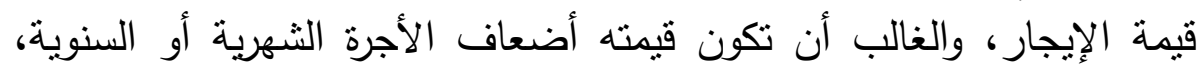

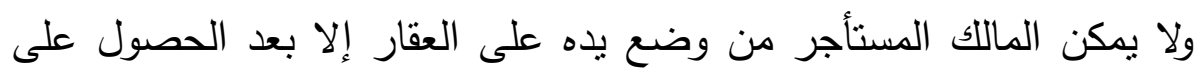

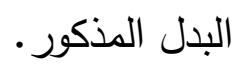

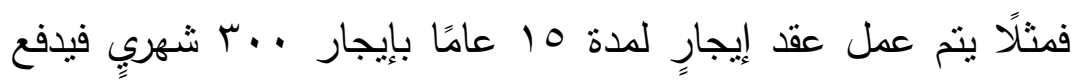
المستأجر مقدم 10 ألف جنيهٍ تخصم من قيمة الإيجار.

(1) قرار مجمع الفقه الإسلامي بجدة رقم ع ؛(T/7) في دورته الخامسة.

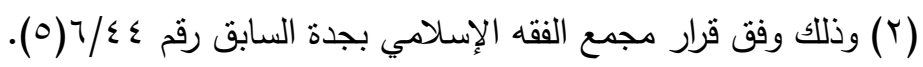


وما أفتى به كثيرٌ من العلماء والهيئات ولجان الفتوى: أن هذا المال جائزٌ ويعتبر ملكًا للمؤجر إذا تم احتسابه من القيمة الإيجارية وتم خصمه منه ونه

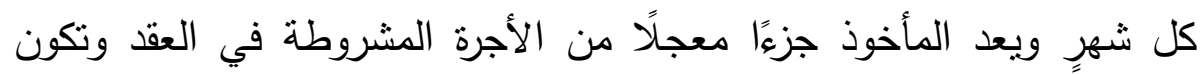

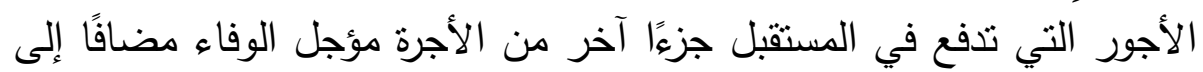

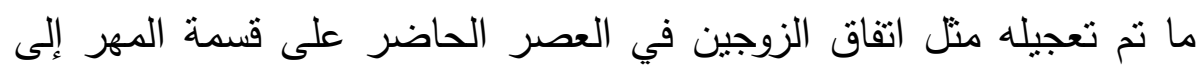
معجلٍ ومؤجلٍ (') - معاله وفي حالة الفسخ قبل انتهاء المدة ينطبق على هذا المبلغ أحكام الأجرة.

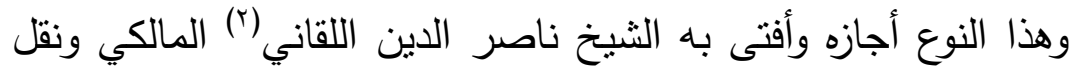

فتواه الشيخ عليش المالكي في فتاويه ونقله أيضا الزرقاني (r).

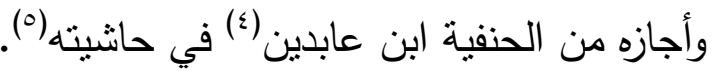

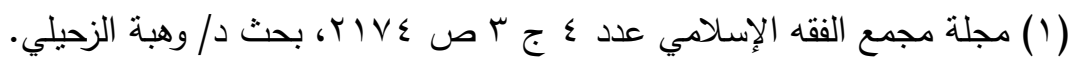

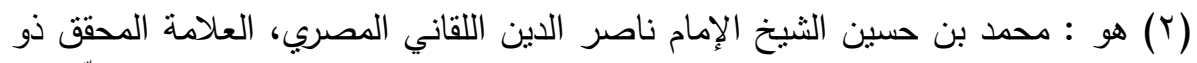

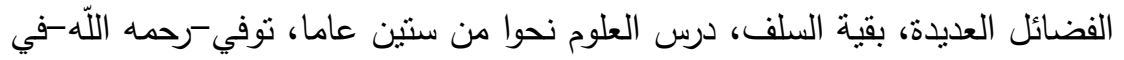

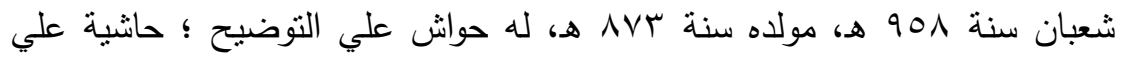

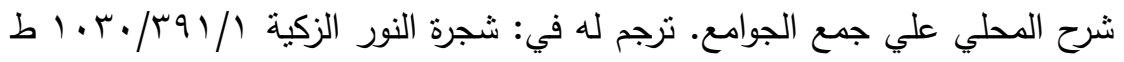

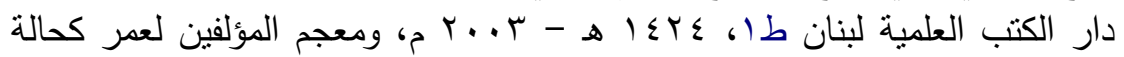

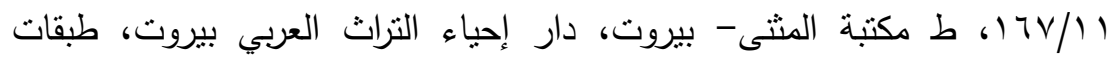

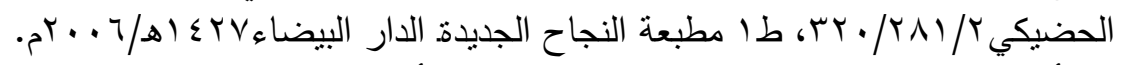

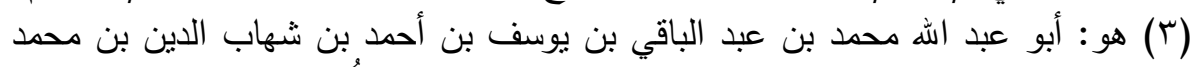

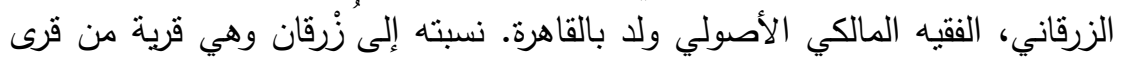

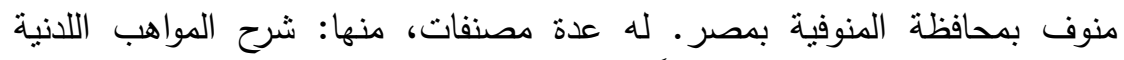

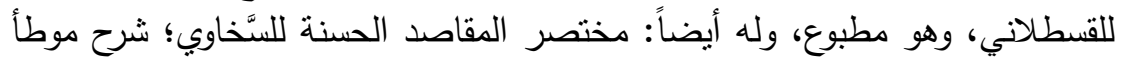

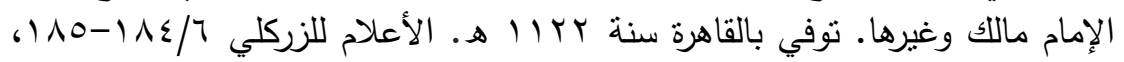

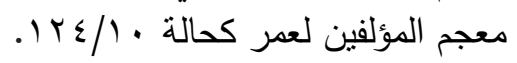

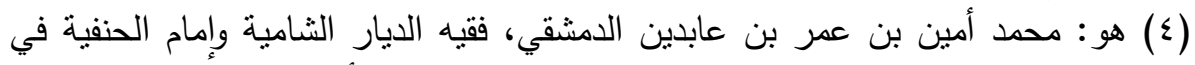

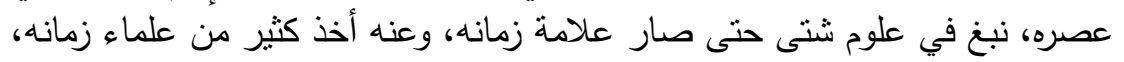

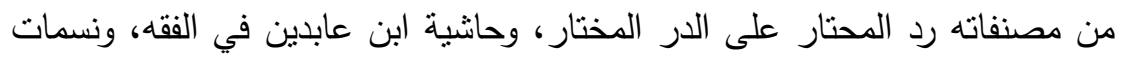

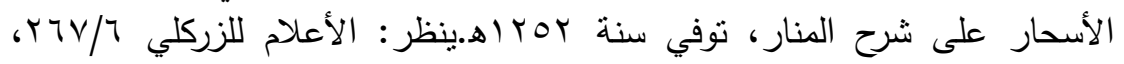

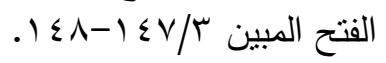

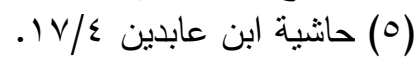


وأجازه من الحنابلة البهوتي (') في مطالب أولي النهى (r) فهذا الثرط من الثروط الجعلية المقيدة للعقد والتي هي في مصلحة أحد المتعاقدين. وجاءت فتاوى العلماء المعاصرين بالجواز وذللك في قرار مجمع الفقه الإسلامي: " أنه لا مانع شرعًا من دفع هذا المبلغ المقطوع على أن يعد جزءاً من أجرة المدة المتفق عليها وهي ليست من الثروط الباطلة أو الفاسدة أو المخالفة للشرع وفي حالة الفسخ يطبق على هذا المبلغ أحكام الأجرة " (ץ). واشترط الشيخ عمر الأشقر في بحثثه عن المسألة أن تعرف نسبة كل من الطرفين من المال كأن يكون للمالك النصف وللمستأجر النصف وينبغي النص على ذلك صراحةً في العقد الذي يبرم بين الطرفين(ء). * $\quad * \quad * \quad * \quad * \quad *$

(1) هو: منصور بن يونس بن صلاح الدين ابن حسن بن إدريس البهوتي الحنبلي: شيخ

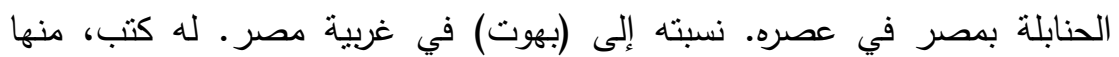
الروض المربع شرح زاد المستقنع المختصر من المقنع، وكثناف القناع عن منت فئن

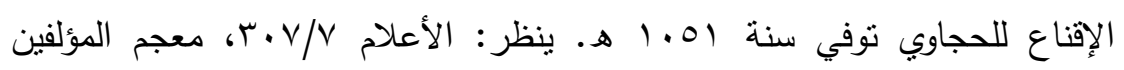
r T/T r السحب الوابلة على ضرائح الحنابلة طا مؤسسة الرسالة.

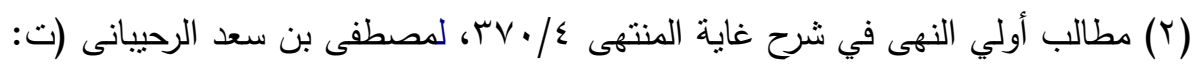

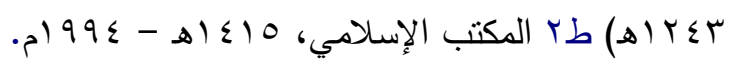

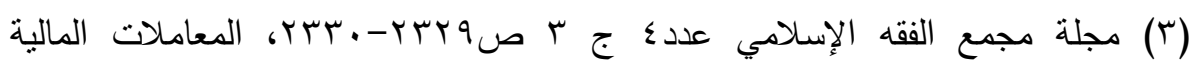

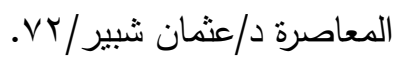

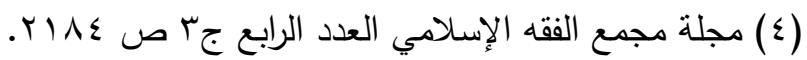




\section{المطاب الثالث : الشرط الجزائي في عقود الإيجار}

الشرط الجزائي: هو اتفاق بين المتعاقدين على تقدير التعويض الذي يستحقه من شرط له عن الضرر الذي يلحقه إذا لم ينفذ الطرف الآخر ما التزم

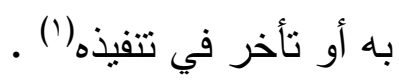

\section{جاء في همبم المصطات المالية والاقتصادية:} " أما تعربف الثّرط الجزائي بمفهوم الحديث: فهو اتفاق بين العاقدين على تقدير مسبق للتعويض الذي يستحقه الدائن أو الملتزم له إذا لم ينفذ الملتزم

أو المدين التزامه أو تأخر في تتفيذه." (؟). وفيما يلي سأذكر بعضًا من الثروط الجزائية المقترنة بعقود الإيجار، اهن

$$
\text { وما ورد فيها من أحكامٍ شرعيةٍ: }
$$

\section{أهثلة الشرط الجزائي على عقود الإيجار: -}

المثال الأول: في عقود الإيجار الخاصة بإيجار عينٍ منل شقةٍ أو دكانٍ بالتزام الطرف الثاني بالمدة الإيجارية وفي حال عدم استكمال المستأجر لهذه المدة يتحمل دفع مبلغ معينٍ للطرف الأول أو الثرط الجزائي المقترن بعقد إجارة الأرض الزراعية والذي يتضمن تعويض المؤجر عن تأخر تسليم الأرض الزراعية خاليةً من الزراعة عند وقت الارضيه انتهاء

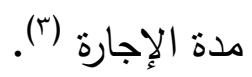

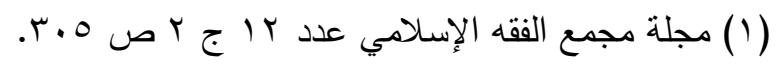

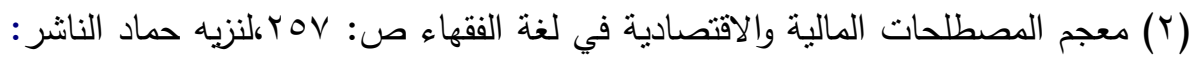

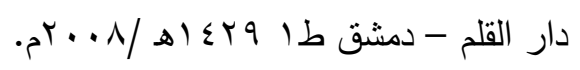

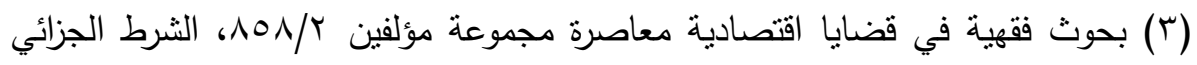
وأثثره في العقود المعاصرة د/ محمد اليمني/ آبآ وما بعدها. 


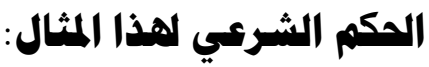

الذي عليه كثيرٌ من الفقهاء المعاصرين أن الثرط الجزائي جائزّ وأنه

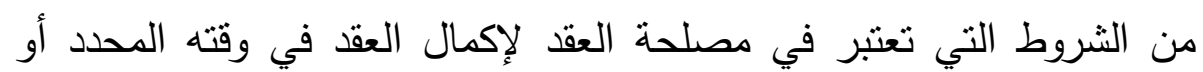
تسليم العين المؤجرة في وقتها المحدد.

\section{والدليل على جوازه:}

ا ـ ما رواه البخاري في صحيحه بسنده عن ابن سيرين ('أن رجلاً قال لكريه

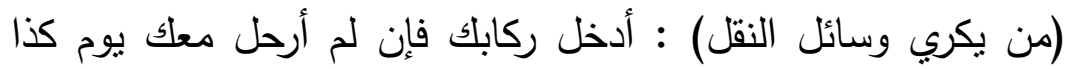

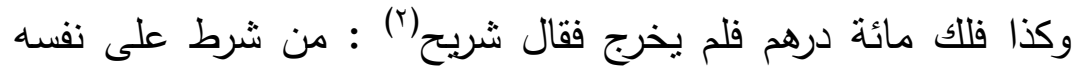
طائعًا ليس مكره فهو عليه (َ). وجه الدلالة: فالثرط الجزائي شرع سدًا لأبواب الفوضى والتلاعب وسببًا لدفع الناس للوفاء بالعقود تحقيقًا لقوله تعالى :

(1) هو: أبو بكر محمد بن سيرين البصري وهو أحد الفقهاء من أهل البصرة، والدذكور بالورع في وقته. وكانت له اليد الطولى في نعبير الرؤيا. وكانت ولادته لسنتنين بقينا من خلافة عثمان، وتوفي ثاسع شوال يوم الجمعة سنة عشر ومائة بالبصرة.

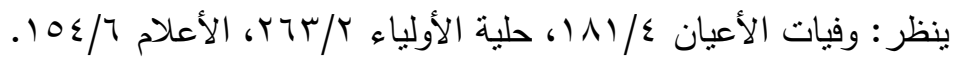
(r) هو : شريح بن الحارث بن قبس بن الجهم الكندي، أبو أمية: من أثهر القضاة الفقهاء

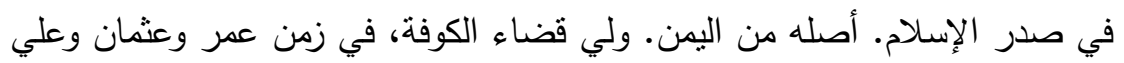
ومعاوية، واستعفى في أيام الحجاج، فأعفاه سنة VV هـ وكان ثقانة في الحديث، مأمونا

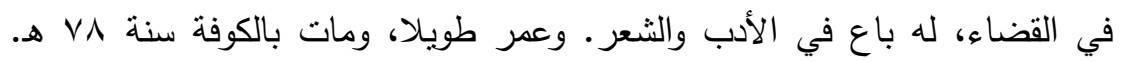

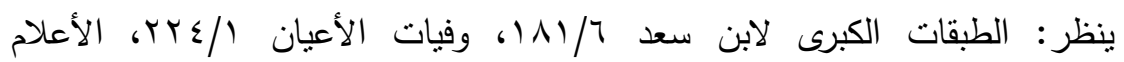
$.171 / \%$

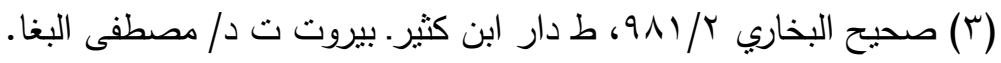




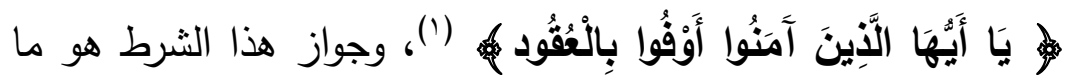

أفنى به كثيرٌ من العلماء والهيئات ولجان الفتوى (؟).

\section{ولكن اشترط العلمهاء شرطين:}

الأول: ألا يكون هناك عنرّ في الإخلال بالالتزام الموجب له معتبرُ شرعًا فيكون العذر مسقطًا للشرط الجزائي حتى يزول.

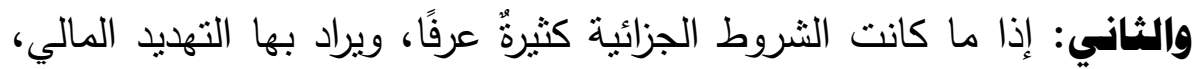

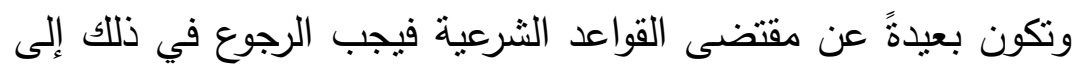

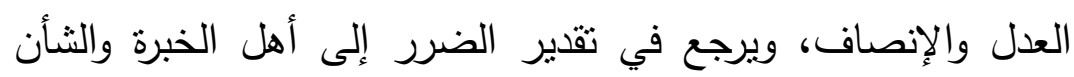
في ذلك.

المثال الثاني: في عقود الإيجار الخاصة بإيجار عين مثل شقةٍ أو دكانٍ يلتزم

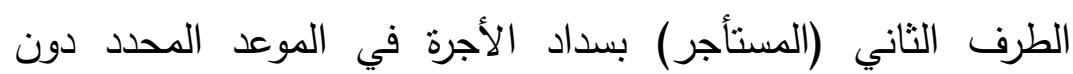

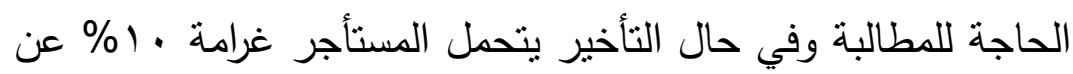

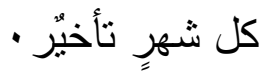
الحكم الشرعي لهذا المثال: أن الشرط الجزائي فيه غير جائزٍ؛ لأن سداد الأجرة هو دينٌ على المستأجر والزيادة في الدين بسبب النأخر في لأني السداد من الربا الصريح المنهي عنه.

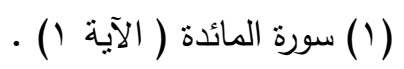

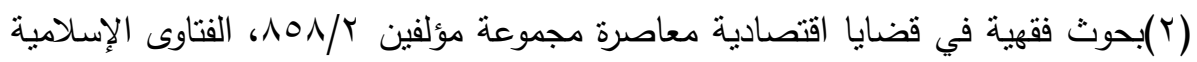

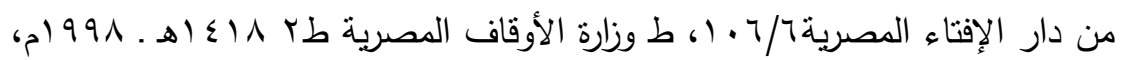
الفناوى الثرعية في المسائل الاقتصادية بيت النمويل الكويتي /.9. 
جاء في فتاوى الثيخ عليش ('): "وأما إذا التزم المدعى عليه للمدعي

أنه إذا لم يوفه حقه في كذا فله عليه كذا وكذا، فهذا لا يختلف في بطلانه؛ لأنه صريح الربا وسواء كان الثيء الملتزم به من جنس الدين أو غيره، وسواءٌ كان شينًا معينًا أو منفعًة" (r). وهو من الربا المشابه لربا الجاهلية بقولهم: (إما أن تقضي وأما

أن تربي).

وبهذا جاء قرار مجمع الفقه الإسلامي بجدة في دورته الثانية عشر ا إ ا هـ، بعدم جواز الزيادة في الديون عند التأخير، كما نص في قراره بالبيع بالتقسيط رقم 101 : إذا تأخر المشتري المدين في دفع الأفساط بعد الموعد المحدد، فلا يجوز التزامه أي زيادٍة على الدين بشرطٍ سابقٍ أو بدون شرطٍ؛ لأن

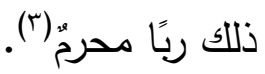

(1) هو: محمد بن أحمد بن محمد عليش، أبو عبد الله: فقيه، من أعيان المالكية. مغربي

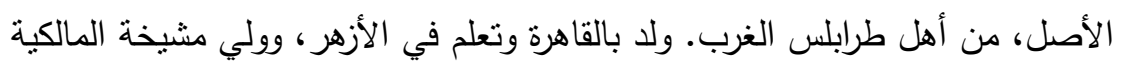

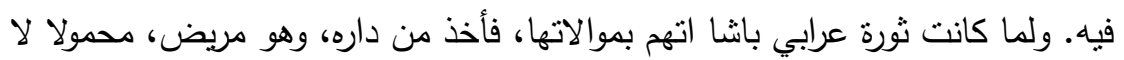
حراك به، وألقي في سجن المستشفى، فتوفي فيه، بالقاهرة. من تصانيفه (فتح العلي

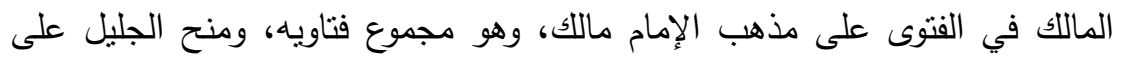

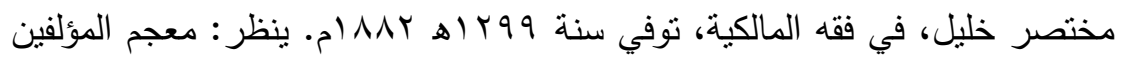

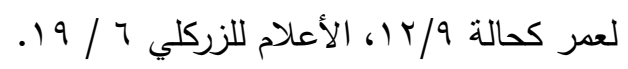

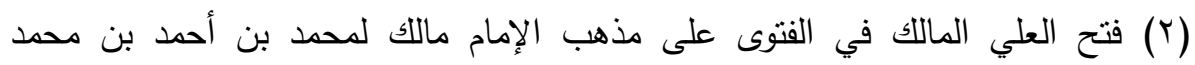

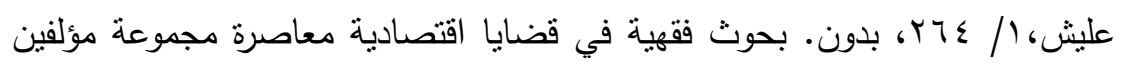
$. \wedge 7 \wedge / r$

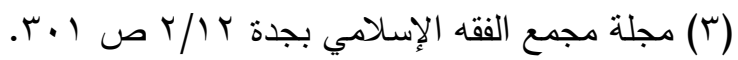


المثال الثالث: الثرط الجزائي على الأجير الخاص في عقود العمل في حال

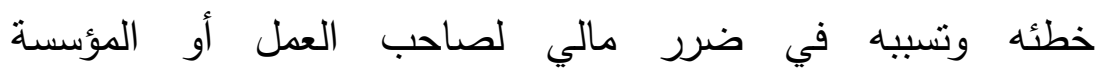
والذي يتضمن خصم مبلغٍ معينٍ من أجرة العامل إذا أخل بالتزاماته

المختلفة (').

المكم الشرعي لهذا المثال: أن الثرط الجزائي فيه جائزّ إن كان الخطأ بسبب

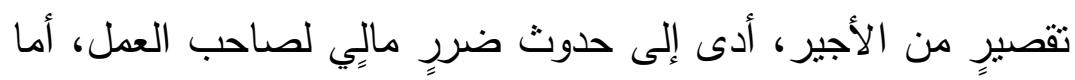

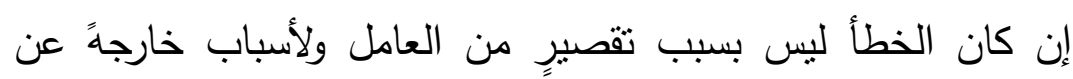

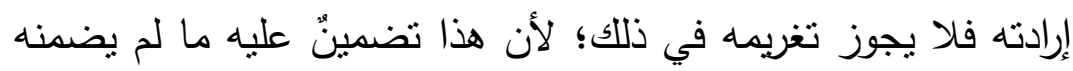

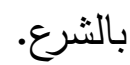

المثال الرابع: الثرط الجزائي على الأجير الخاص في حال تأخره عن أوقات العمل بخصم أيارٍ من أجره المستحق. المكم الشرعي لهذا المثال: أن الثرط الجزائي فيه جائزٌ ؛ لأنه ناتجٌ عن الهن إهمالٍ وتقصيرٍ من العامل والمؤمنون عند شروطهم، واستصحابًا للأصل الذبي هو جواز أي معاملةٍ ما لم يأت دليلّ على منعها وبناءًا على قول الأكثر وهو أن الأصل في الثروط الصحة. * $\quad * \quad * \quad * \quad * \quad *$ ( (1) بحوث فقهية في قضايا اقتصادية معاصرة مجموعة مؤلفين T/1 1 1 . 


\section{المطلب الرابع : حكم الإيجار المؤبد المعروف بالإيجار القديم}

وهو من الثروط الجعلية التي فرضها القانون الوضعي في عقود الإيجار للعقارات أو المحلات أو الأراضي الزراعية.

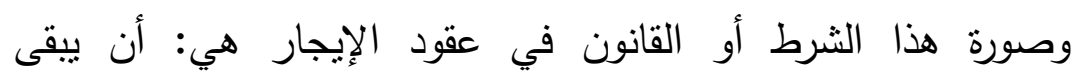
المستأجر مدى الحياة في العين المؤجرة بنفس القيمة الإيجارية ويورثها لجيل

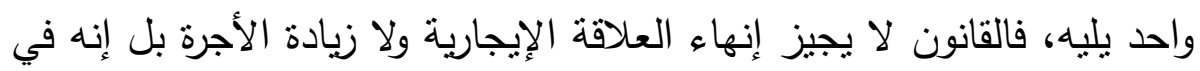
حالة وفاة المستأجر يمكن لأحد أبناءه تكملة عقد الإيجار . فما هكم هذا الشرط أو هذا القانون في عقود الإيمار؟

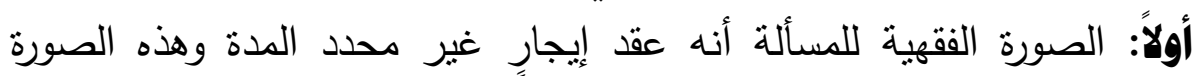
اختلف فيها الفقهاء:

ا. فالثافعية والحنابلة: على أنه عقدٌ باطلٌ؛ لأنه لابد من تحديد مدته لتتفي

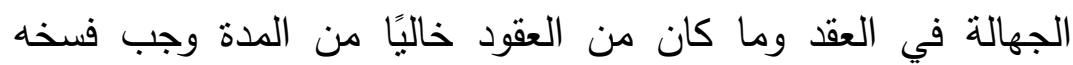
وإنثاء العقد مرةً أخرى مع تحديد مدة الإجارة.

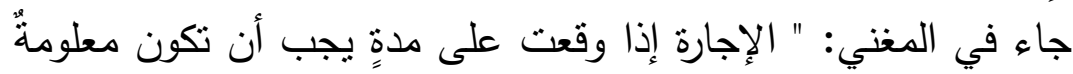
كثهرٍ وسنةٍ ولا خلاف في هذا نعلمه؛ لأن المدة هي الضابطة للمعقود عليه المعرفة له فيجب أن تكون معلومةٌ "( (1). r. القول الثاني للحنفية والمالكية وبعض الحنابلة وأبي ثور (؟): أنه عقدٌ صحيُح ويسمى عقد المشاهرة، لكنه غير ملزم لأحد الطرفين فأيهما أراد فسخ

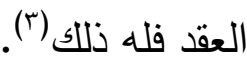

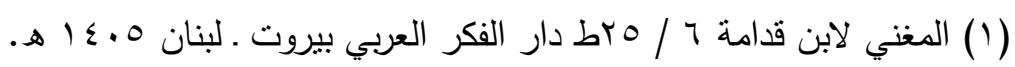

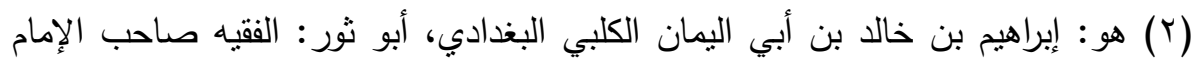

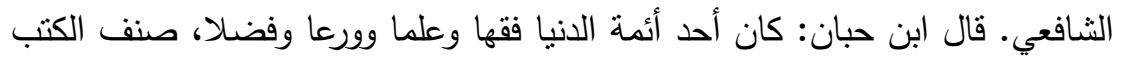

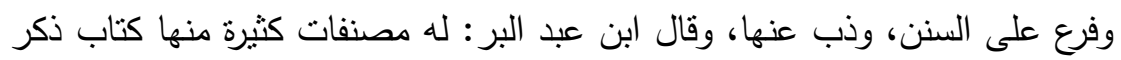

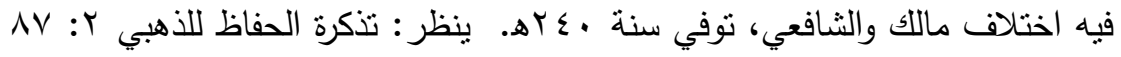

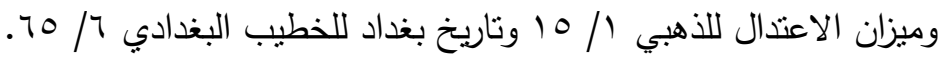

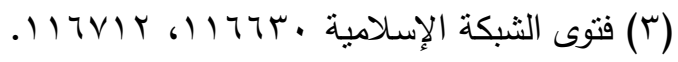


جاء في الشرح الكبير: " وجاز الكراء مشاهرة وهو عبارة عندهم عما عبر فيه بكل نحو كل شهر بكذا أو كل يوم أو جمعة وكل سنة بكذا ولم يلزم الكراء لهما فلكل من المتكاريين حله عن نفسه متى شاء ولا كلام للآخر ...إلى أن قال: إن المشاهرة لقب لمدة غير محدودة "('). فعلى القول بصحة العقد فإن لكل واحد من المتعاقدين فسخه منى شاء.

وبهذا يتضح أن عقد الإيجار القديم بصورته وشروطه التي فرضها القانون من العقود الباطلة المصادمة للشريعة بل قد نقل ابن قدامة الإجماع عن ابن المنذر(r) على ذلك فقال: "أجمع كل من نحفظ عنه من أهل العلم على أن استئجار المنازل جائز ولا تجوز إجارتها إلا في مدة معينة معلومة "().

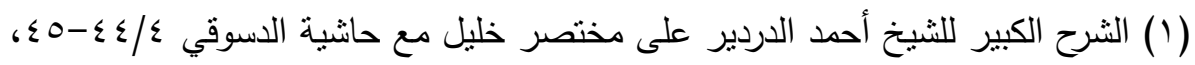

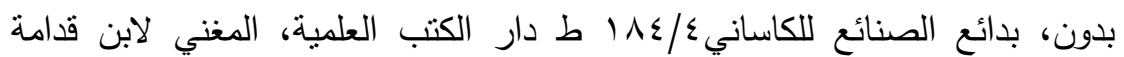
.ro/

(Y) هو : أبو بكر محمد بن إبراهيم بن المنذر النيسابوري الحافظ العلامة الثقة الأوحد، شيخ الحرم وصاحب الكتب التي لم يصنف منلها الأثراف والمبسوط والإجماع والتقسير .

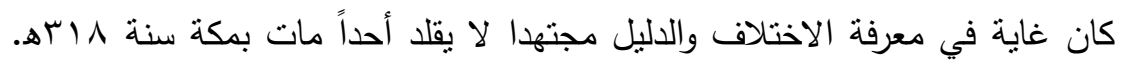

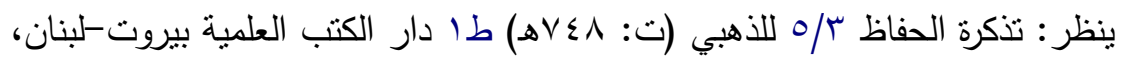

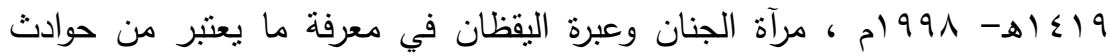

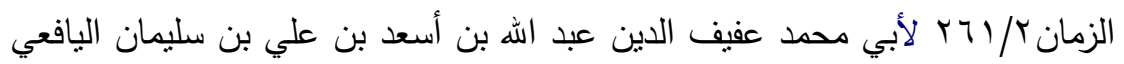

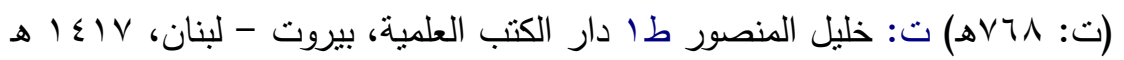

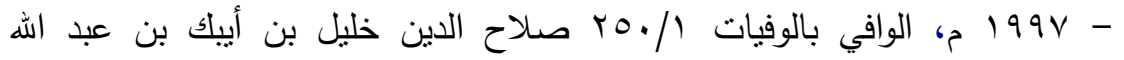

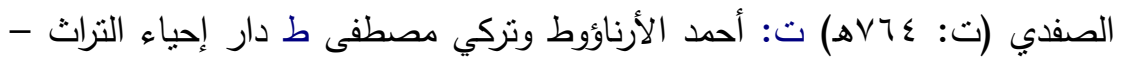

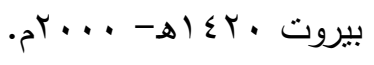

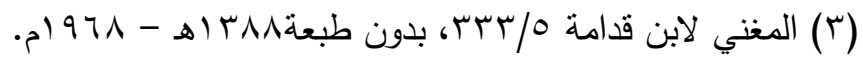


وهذا نص الإجماع الوارد عن ابن المنذر: "وأجمعوا على إجازة أن

يكري الرجل من الرجل دارًا معلومة قد عرفاها وقنًا معلومًا بأجرٍ معلوِم"('). فليس للمسلم البقاء على هذا الإيجار أو يتكئ على قوانين تسمح له هله بذلك، فتأبيد الإجارة يجعل المستأجر مالكًا أو كالماللك كما أنه يؤدي إلى أكل أموال الناس بالباطل؛ بل إن المستأجر يعتبر غاصباً لملك غيره لو طلب منه المالك الخروج أو زيادة الأجرة ولم يفعل، وجب عليه إخلاء العين أو البقاء برضا المالك بعقدٍ جديدٍ وإيجارٍ ومدةٍ محددةٍ.

* $\quad * \quad * \quad * \quad * \quad *$

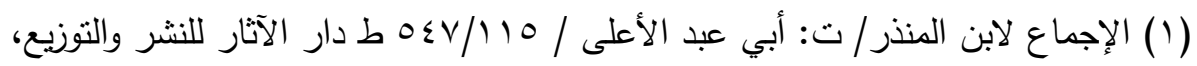

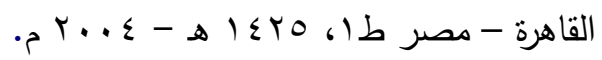




\section{المطلب الخاهس : حكم اشتراط صيانة العين المؤجرة}

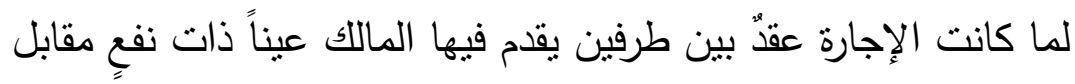

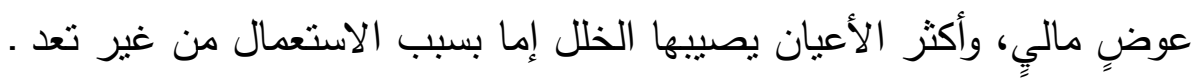
أو عوارض أخرى فتثور مشكلاتُ بين الطرفين في تكلفة صيانة ذلك الخلل. لذلك اهتمت الجهة المنظمة لعقود الإيجار باشتراط ذلك في العقد وخصوصاً في إيجار المعدات والعقارات الكبيرة وعني الفقهاء ببيان حكم ذلك للكئل قديماً وحديثاً.

\section{وقد قسم العلهاء صيانة العين المأجورة إلى قسيهين:}

الأول: الصيانة الأساسية التي يتوقف عليها الانتفاع بالعين المستأجرة واللازمة لبقاء العين المؤجرة، متل إصلاح الجدار المهدوم، وترميم السقف الذي لهي

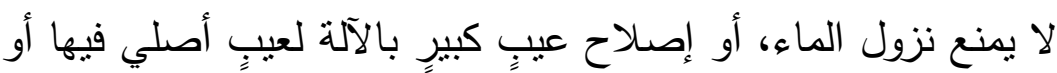

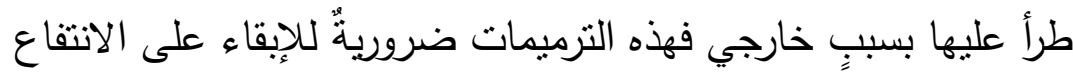

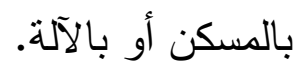

الثاني: الصيانة النتشغيلية العادية التي تحتاج إليها المساكن المؤجرة نتيجة الاستعمال منل صيانة وتغيير الأشياء التي تُشتهلك، وتتلف في فتراتٍ دوريةٍ بسبب الاستعمال، كتغيير وإصلاح أجهزة ومفاتيح الإنارة الكهربائية وأيدي الأبواب والثبابيك والحنفيات والطرطشة والدهان وتغيير بلاطةٍ كُسرت ونحوها وكذلك ما تحتاجه الآلة من تغيير زيتٍ

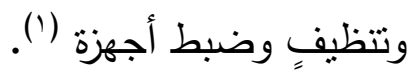

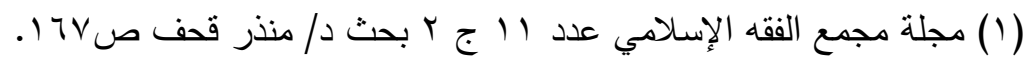




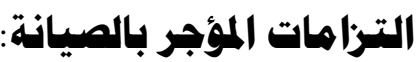

قرر الفقهاء أن الصيانة الأساسية التي يتوقف عليها بقاء العين المؤجرة

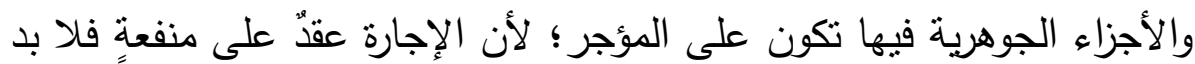
من صيانة ما يجعلها صالحةً للبقاء والانتفاع '(').

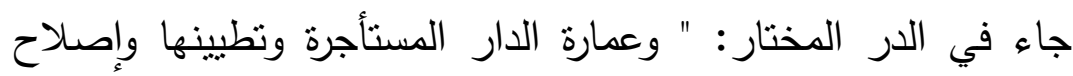

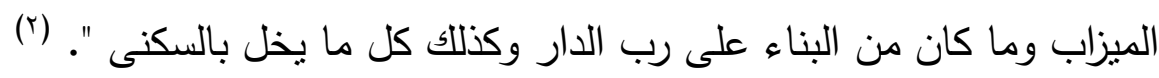

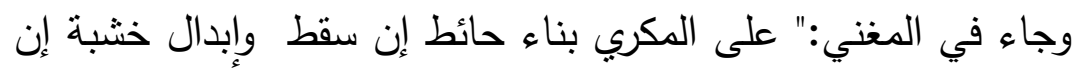
انكسرت وعليه تبليط الحمام، وإن شرط هذا على المكتري فالثرط فاسدٌ؛ لأن العين ملكُّ للمؤجر فنفقتها عليه ". (r)

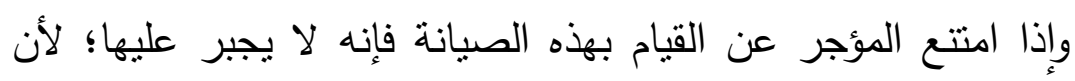
المالك لا يجبر على إصلاح ملكه وللمستأجر أن يخرج وله حق فسخ الإجارة لعدم تمكنه من الانتفاع بالعين المؤجرة ، هذا رأي جمهور الفقهاء (ئ.

(1) بحوث فقهية في قضايا اقتصادية معاصرة بحث صيانة الأعبان المؤجرة د/ محدد عثمان شبير صنr vor.

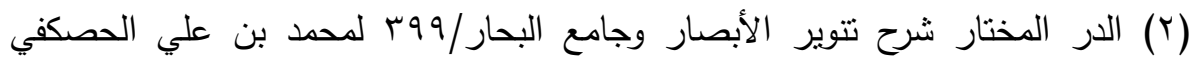

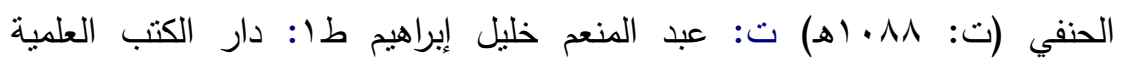

$$
\text { r. }
$$

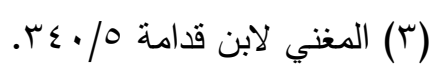

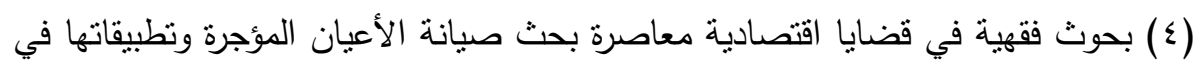

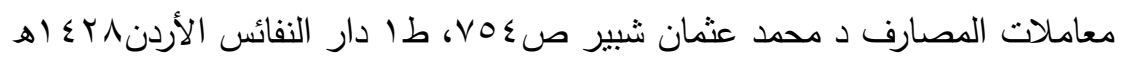

$$
.01991-
$$




\section{التزاهات المستأجر بالصيانة:}

يتحمل المستأجر تبعة الصيانة التتخيلية الناتجة من استعماله أو

الناتجة من إهماله وتقصيره، أو ما يتعلق بحفظ العين المؤجرة، متل كسح النلج

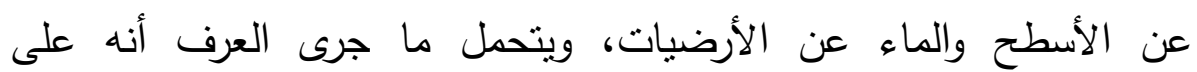
المستأجر إن كان العقد بدون شرط، فإن كان هناك شرط عمل به؛ لأن الثرط الثراء مقدمّ على العرف.

\section{حكم الشرط بالصيانة على المؤجر:}

يجوز أن يشترط المستأجر على المؤجر في العقد أب نوعِ من

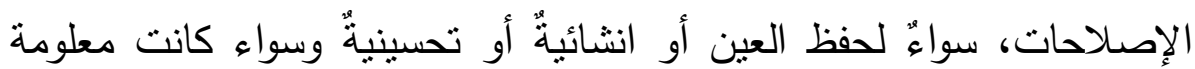
التكلفة أو غبر معلومة ولا ضرر في ذلك؛ لأن هذه التكلفة تضاف إلى العين

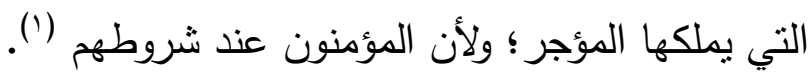
حكم الشرط بالصيانة على المستأجر:

وهذا يختلف باختلاف نوع الصيانة المشروطة على المستأجر:

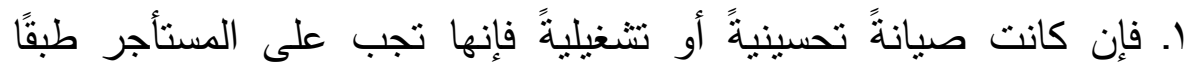
للشرط بالعقد. r. وإن كانت صيانةً أساسيةً كإصلاح حائطٍ أو أرضياتٍ أو صيانةً أساسيةً

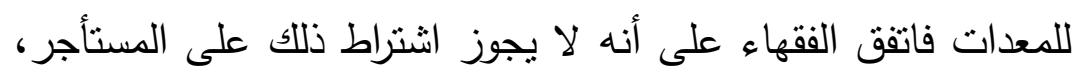
والثرط غير صحيحٍ والعقد فاسدُ.

(') بحوث فقهية في قضايا اقتصادية معاصرة بحث عقد صيانة الأعيان المؤجرة وتبعية

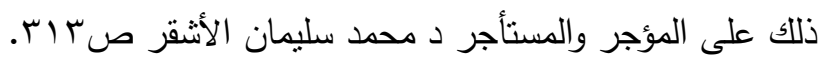


قال السرخسي ('): " فإن اشترط المرمة على المستأجر فسدت الإجارة؛

لأن المرمة على الآجر فهذا شرط مخالف لمقتضى العقد"(؟).

ولأنه تكليفُ زائدُ على الأجرة ومنفعةٌٌ للمؤجر وفيه جهالةُ؛ لأن أعمال

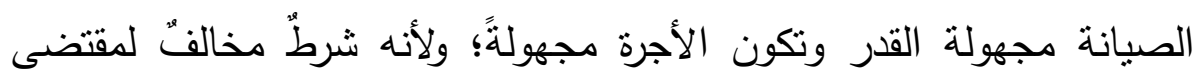
العقد وهو أن تبعة الصيانة لأصل العين المؤجرة تكون على المؤجر لا على

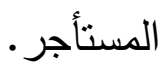

ولكن يمكن تصحيح هذا الثرط بأن تحدد قيمة أعمال الصيانة لأصل

العين المؤجرة، بحيث تخصم تلك القيمة من الأجرة، ويمكن بذلك تصحيح الشرط والعقد.

جاء في المبسوط: " ولو اشترط عليه رب الحمام عشرة دراهم في كل شهر لمرمته مع الأجرة وأذن له أن ينفقها عليه فهو جائزٌ؛ لأنه معلوم المقدار وقد جعله نائبًا عن نفسه في إنفاقه على ملكه " (َ). فإذا تحددت قيمة أعمال الصيانة حسم المستأجر تلك القيمة من الأجرة باعتباره وكيلً عن المؤجر وإذا كانت لِما سيحدث في العين المؤجرة فيصح إذا أَذِنَ له في الصيانة وخصم ذلك من الأجرة.

(1) هو : محمد بن أحمد بن سهل أبو بكر شمس الأئمة السرخسي قاضى من كبار الأحناف

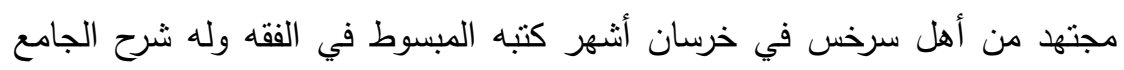
الكبير وشرح السير الكبير توفى سنة بهـهـ (ينظر: الطبقات السنية في تراجم

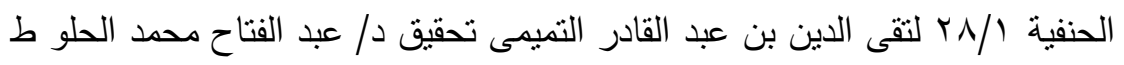

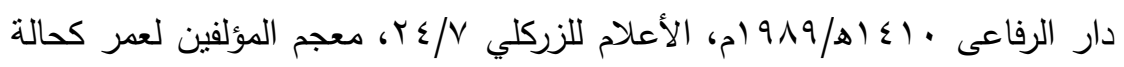
rrq/A

$$
\begin{aligned}
& \text { (Y) المبسوط للسرخسي OV/10، بدون. }
\end{aligned}
$$

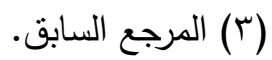


وجاء قرار مجمع الفقه الإسلامي في دورته الحادية عشر موافقًا لكل ما

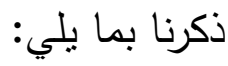

" الصيانة المشروطة في عقد الإجارة على المؤجر أو المستأجر، هذا

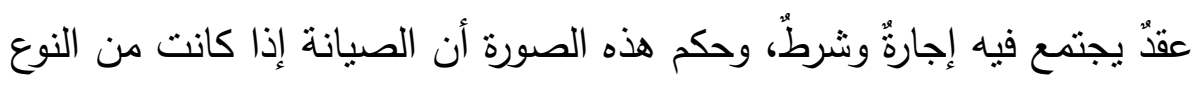
الذي يتوقف عليه استيفاء المنفعة فإنها تلزم ماللك العين المؤجرة من غير شرط، ولا يجوز اشتنراطها على المستأجر، أما الصيانة التي لا يتوقف عليها استيفاء المنفعة فيجوز اشتراطها على أي من المؤجر أو المستأجر إذا عينت تعيينًا نافيًا للجهالة (') - 2 (1)

* $\quad * \quad * \quad * \quad * \quad *$

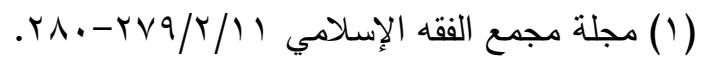




\section{النفاتمـة}

الحمد لله الذي بنعمته تتم الصالحات، والصلاة السلام الأتمان

الأكملان على سيد ولد عدنان وسيد الخلق أجمعين، وعلى آله وصحبه الغر الميامين، ومن سار على نهجهم واقتفى أثزهم إلى يوم الدين.

$$
\text { أما بعد }
$$

فإني أختم بحثي المتواضع بعد حد الله . تعالى . على الإعانة

والتوفيق، بعدة نتائج وتوصياتٍ

\section{أولاً: النتائج فهي كالتالي: بكهُ}

ا. أن الخلاف في تعريف الثرط اصطلاحاً خلافٌ لفظيُ، لا أثر له في

$$
\text { الفروع الفقهية. }
$$

r. أن لفظ الجعل له اطلاقات عديدة منها: أنه مبلغ من المال يعطى لمستأجر في مقابل عمل يسير مرة واحدة، ويطلق على ما يضعه أحد المتعاقدين

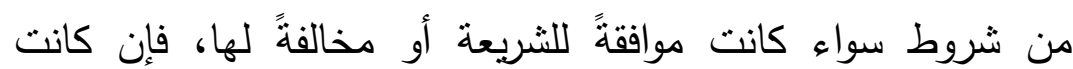

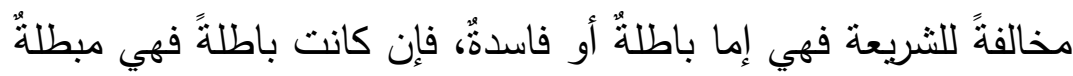

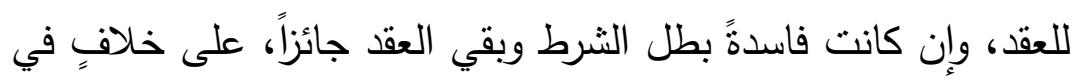
ذلك بين الحنفية والجمهور .

r. أن الشرط علامةٌ على وجود الحكم في حق صاحب الشرط. ع. أن الحكم ينتفي عند عدم وجود الشرط الموافق للشروط الثرعية. ه. أن الجمهور لا يفرقون بين الفاسد والباطل، أما الحنفية فيفرقون بينهما بحسب قوة الاليل وضعفه، أو قطعية الدليل وظنيته. T. أن الجمهور قسموا الثرط الجعلي إلى أربعة أقساهٍ: شرعيٌ وعرفيٌ ولغويٌ ووضعيّ، بينما قسمه الحنفية باعتبارين مختلفين إلى عدة أقسام: - باعتبار مصدره: اتفقوا مع الجمهور لكن زادوا عليه الحقيقي. 
- باعتبار وجود الحكم: إلى محضٍ وله حكم العلل وله حكم السبب، وشرطٌ

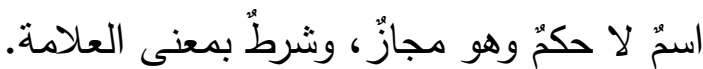

\section{ثانيا: التوصيات:}

ا. الاهنمام بما يستجد من أحكام والاجتهاد في وضع حلول لها، منل هذه

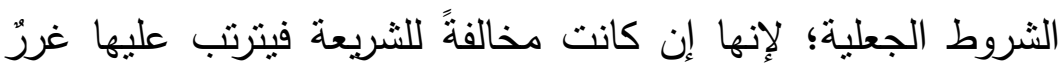

وجهالةُّوبطلان العقد.

r. هناك صوٌر من عقود التأجير المنتهي بالتمليك محل خلاف تحتاج إلى ونى دراسةٍ ولا مجال لدراستها في هذا البحث.

r. الاستفادة من الأبحاث العلمية وتتزيلها على أرض الواقع، لتعم الفائدة. هذا ما انتهيت إليه والحمد لله على توفيقه وسداده.

وصلي اللهم وسلم وبارك على سيدنا محمد وعلى آله وصحبه وسلم، والحمد الله رب العلمين.

* $\quad * \quad * \quad * \quad * \quad * \quad *$ 


\section{فهرس المراجع}

وقد جعلته مرنبًا نرتيبًا أبجديًا

\begin{tabular}{|c|c|}
\hline المدر أو المرجع & $A$ \\
\hline 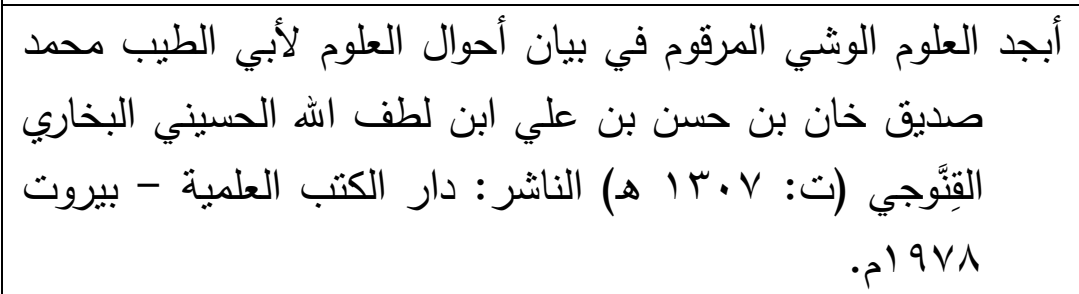 & .1 \\
\hline 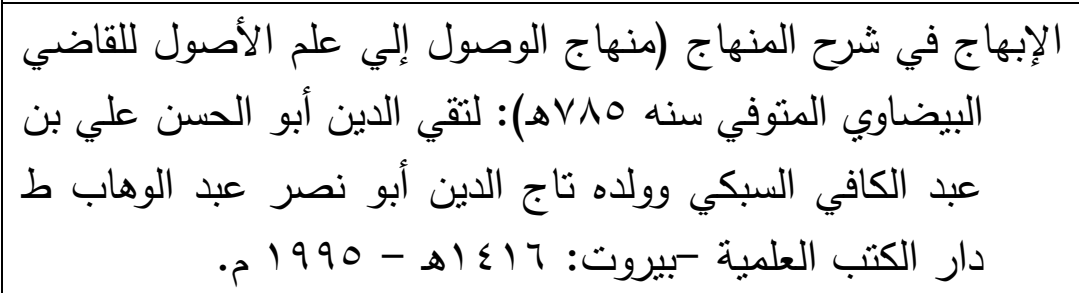 & .4 \\
\hline 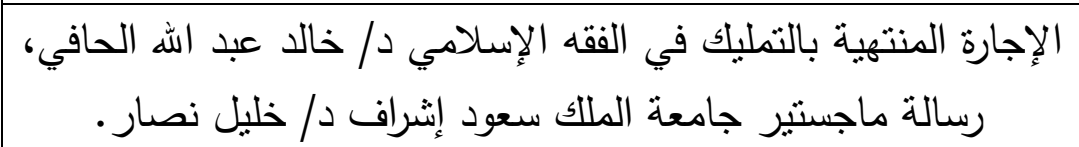 & r \\
\hline 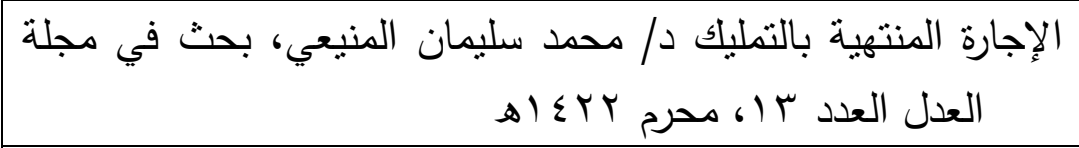 &.$\varepsilon$ \\
\hline 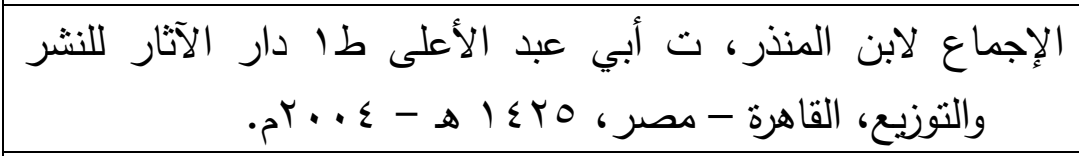 & .0 \\
\hline 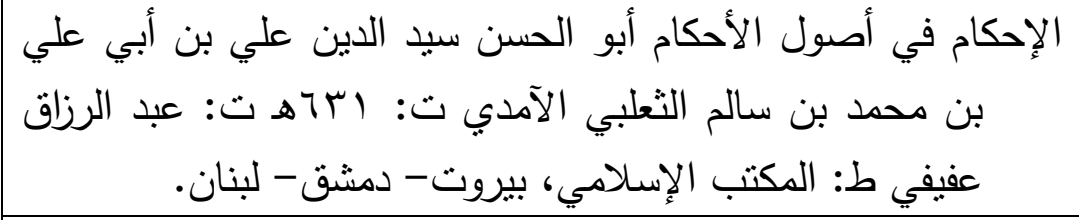 & .7 \\
\hline 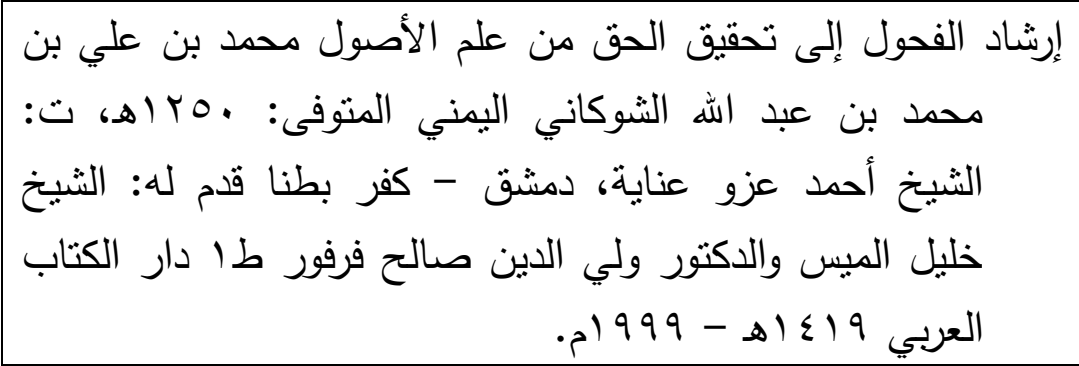 & $\cdot v$ \\
\hline
\end{tabular}




\section{المدر أو المرجع}

^.

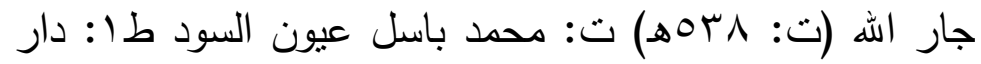

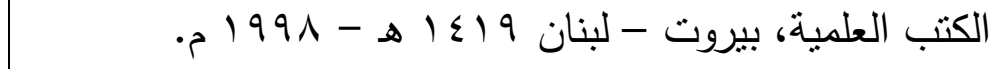
9 9. أصول السرخسي: محمد بن أحمد بن أبي سهل شمس الأئمة

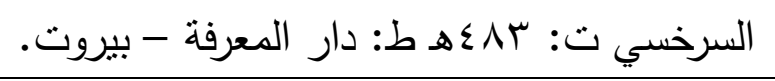

• ا. إعلام الموقعين عن رب العالمين لمحمد بن أبي بكر بن أيوب بن سعد شمس الدين ابن قيم الجوزية (ت:

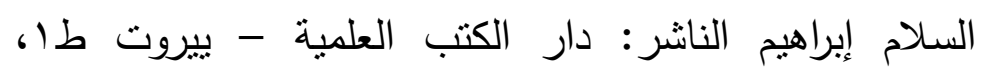

$$
\text { . } 1991-81 \leq 11
$$

11. الأعلام لخير الدين بن محمود بن محمد بن علي بن فارس، الزركلي الدمشقي (ت: جوس أهـ) طها: دار العلم للملايين _ أيار /

مايو r +. .r م.

r ا. الأم للشافعي أبو عبد الله محمد بن إدريس بن العباس بن عثمان بن شافع بن عبد المطلب بن عبد مناف المطلبي القرشي المكي

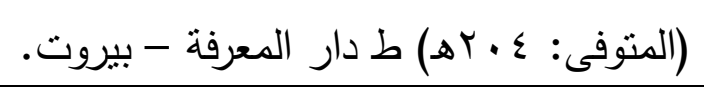

با. البحر المحيط في أصول الفقه لأبي عبد الله بدر الدين محمد بن عبد الله بن بهادر الزركثي ت: ع9 عه طا دار الكتبي

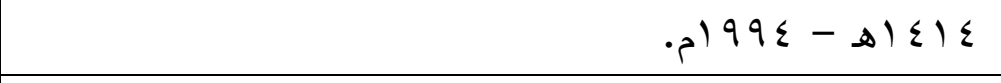

ع ا. بحوث فقهية في قضايا اقتصادية معاصرة بحث صيانة الأعيان

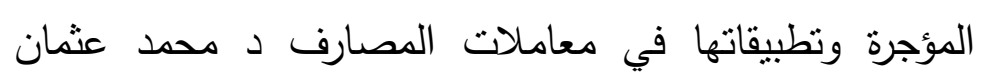

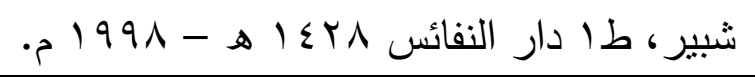




\section{الصددر أو المرجع}

1. بحوث فقهية في قضايا اقتصادية معاصرة بحث عقد صيانة الأعيان المؤجرة وتبعية ذلك على المؤجر والمستأجر د محمد سليمان

الأشقر.

17 ا بداية المجته ونهاية المقتصد لأبي الوليد محمد بن أحمد ابن رشد الحفيد (ت:

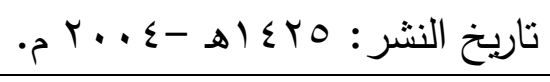

IV البصري ثم الدمشقي (المتوفى: ع \&هـ) ط دار الفكر عام

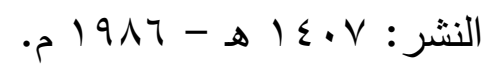

11. بدائع الصنائع في ترتيب الثرائع لعلاء الدين، أبو بكر بن مسعود بن

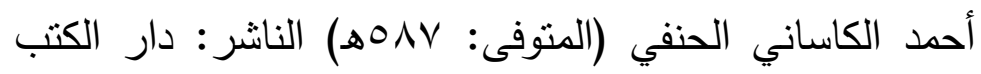

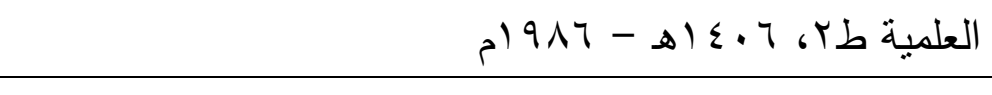

19 1. البدر الطالع بمحاسن من بعد القرن السابع لمحمد بن علي بن محمد بن عبد الله الثوكاني اليمني (المتوفى: .0 ب اهـ) الناشر :

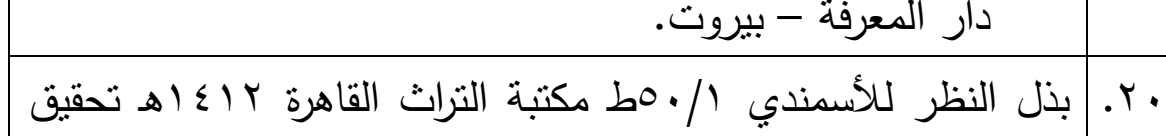

$$
\text { د/ محمد زكي عبد البر . }
$$

ا Y. بلغة السالك لأقرب المسالك المعروف بحاثية الصاوي على الثرح الصغير (الثرح الصغير هو شرح الثيخ الدردير لكتابه المسمى

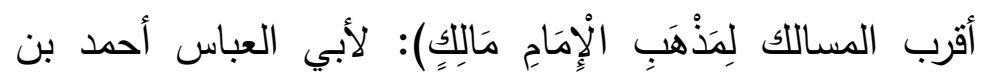

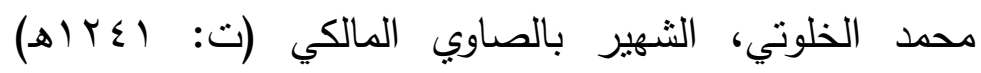

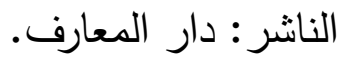




\section{الصددر أو المرجع}

r r. بلوغ المرام من أدلة الأحكام لأبي الفضل أحمد بن علي بن محمد بن أحمد بن حجر العسقلاني (ت:

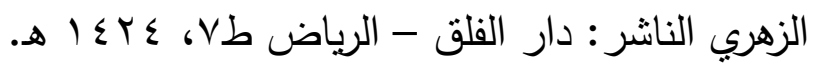

rr. بيان المختصر شرح مختصر ابن الحاجب: محمود بن عبد الرحمن (أبي القاسم) ابن أحمد بن محمد، أبو الثناء، شمس الدين

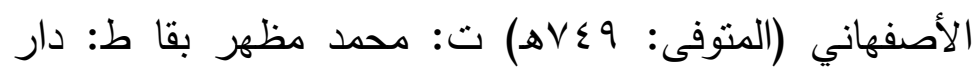
المدني، السعودية. ت: فخر الدين سيد محمد قانت (رسالة

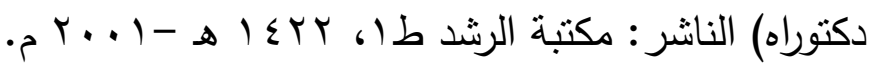
ع ז. تاج العروس من جواهر القاموس: محمّد بن محمّد بن عبد الرزّاق

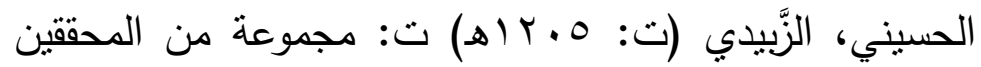
الناشر : دار الهداية. Or. تاريخ الإسلام ووفيات المشاهير والأعلام لشمس الدين أبو عبد الله

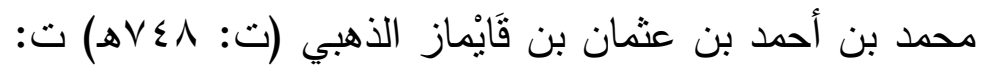
عمر عبد السام التذمري الناشر: دار الكتاب العربي، بيروت

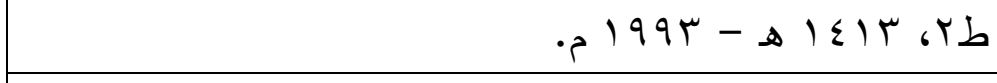

Tr. تاريخ بغداد لأبي بكر أحمد بن علي الخطيب البغدادي (ت:

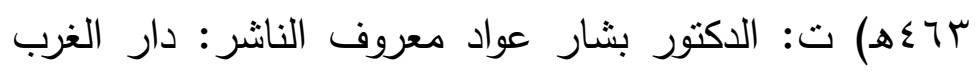

$$
\text { الإسلامي - بيروت، ت: عبد الجبار زكار . }
$$

rV ت تخكرة الحفاظ لشمس الدين أبو عبد الله محمد بن أحمد بن عثمان بن

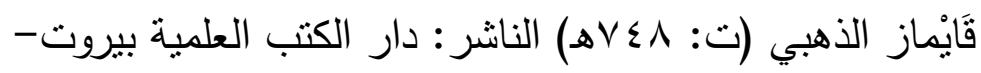

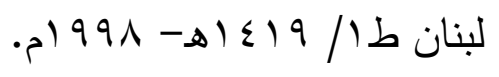




\section{الصدر أو المرجع}

^r. التقربر والتحبير : أبو عبد الله، شمس الدين محمد بن محمد بن محمد

المعروف بابن أمير حاج ويقال له ابن الموقت الحنفي (ت:

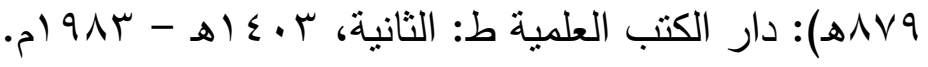

qץ. تيسير التحرير لمحمد أمين بن محمود البخاري المعروف بأمير

بادشاه الحنفي ت: 9VT هـ، ط مصطفى البابي الْحَبِي - مصر

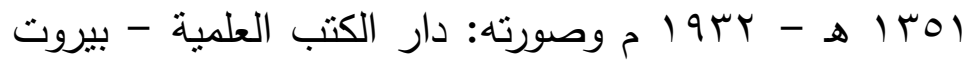

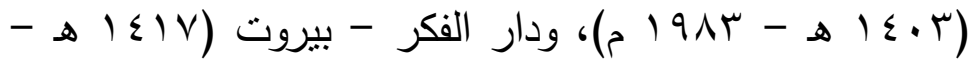

$$
\cdot(\text { ) } 1997
$$

• r. تيسيرُ علم أصول الفقه لعبد الله بن يوسف بن عيسى بن يعقوب اليعقوب الجديع العنزي طا مؤسسة الريان للطباعة والنشر

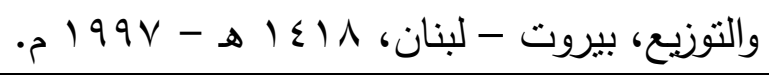

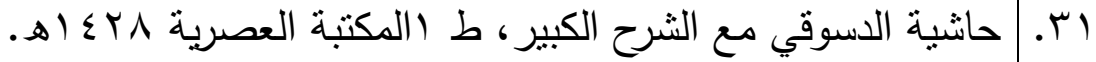
rr. حاشية رد المحتار ابن عابدين، محمد أمين بن عمر بن عبد العزيز

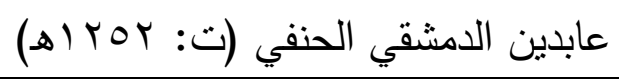

سب. حاشيتا قليوبي وعميرة لأحمد سلامة القليوبي وأحمد البرلسي عميرة الناشر : دار الفكر - بيروت ط: بدون 10 ع إهـ-990 (م.

عـ. حروف المعاني بين دقائق النحو ولطائف الفقه د / محمود سعد ط

$$
\text { (9 ام سور الأزبكية. }
$$

هr. الدر المختار شرح تتوير الأبصار وجامع البحار لمحد بن علي الحصكفي الحنفي (ت: 1 1 • (ه) ت: عبد المنعم خليل إبراهيم

$$
\text { طا : دار الكتب العلمية سrع اهـ-r. . .rم. }
$$




\section{المدر أو المرجع}

جس. الدرر الكامنة في أعيان المائة الثامنة لأبي الفضل أحمد بن علي بن محمد بن أحمد بن حجر العسقلاني (ت:

عبد المعيد ضان الناشر: مجلس دائرة المعارف العثمانية -

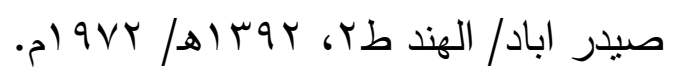

V V. روضة الطالبين وعمدة المفتين لأبي زكريا محيي الدين يحيى بن شرف النووي (ت: 7VTهـ ت ت زهير الثاويش الناشر: المكتب

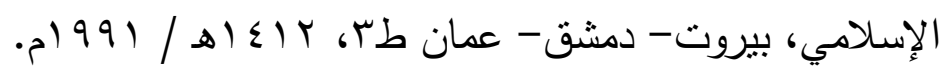
مץ. روضة الناظر وجنة المناظر في أصول الفقه على مذهب الإمام أحمد بن حنبل أبي محمد موفق الدين عبد اله بن أحمد بن محمد بن قدامة الجماعيلي المقدسي ثم الدمشقي الحنبلي، الثهير بابن قدامة المقدي (ت: • r T هـ) طب مؤسسة الريّان

$$
\text { . }
$$

qr. روضة الناظر وجنة المناظر في أصول الفقه على مذهب الإمام أحمد بن حنبل لأبي محمد موفق الدين عبد اله بن أحمد بن محمد بن قدامة المقدسي (ت: · rTهـ) طب مؤسسة الريّان

$$
\text { מ }
$$

• ع. سبل السلام لمحمد بن إسماعيل بن صلاح بن محمد الحسني،

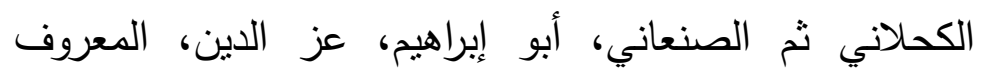

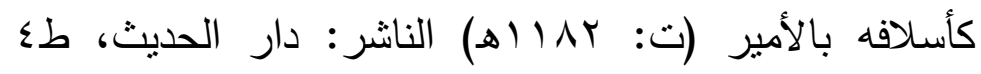

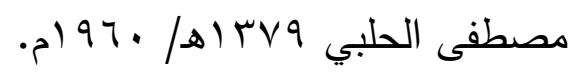




\section{المدر أو المرجع}

اء. السحب الوابلة على ضرائح الحنابلة لمحمد بن عبد الله بن حميد

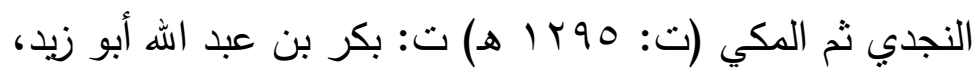
عبد الرحمن بن سليمان العثيمين الناشر: مؤسسة الرسالة

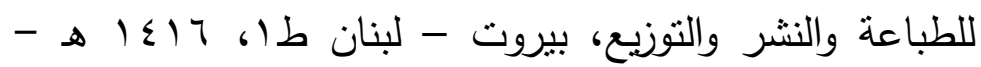
r العثماني المعروف بـ اكاتب جلبيه وب لاجاجي خليفةه (ت

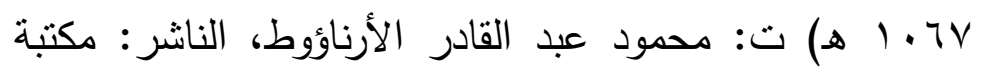

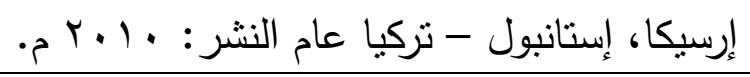

rع. محمد بن عيسى بن سَوْرة بن موسى بن الضحالك، الترمذي، أبو

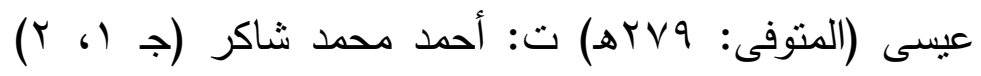

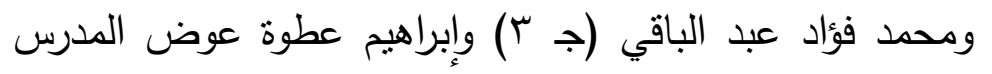

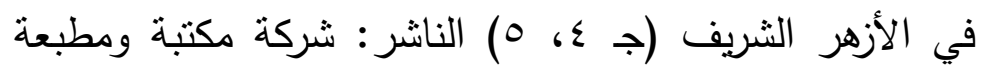

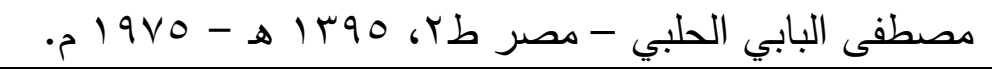

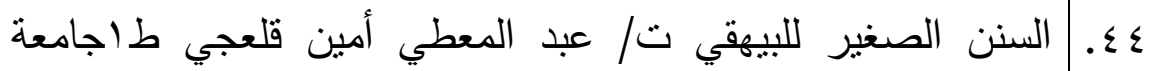

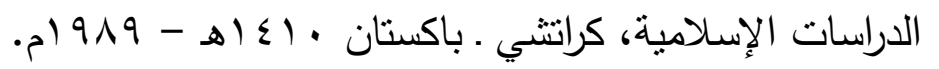

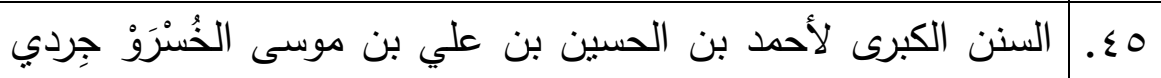

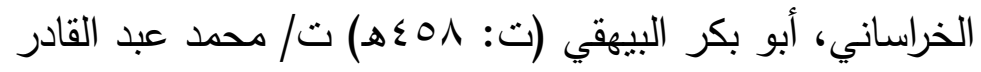

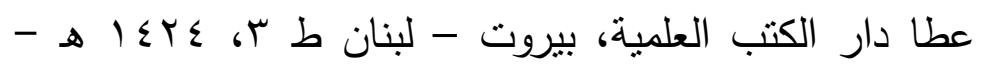

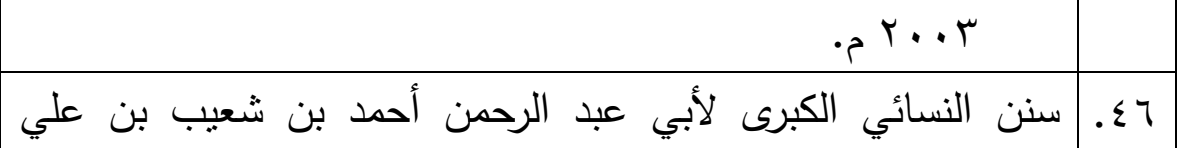

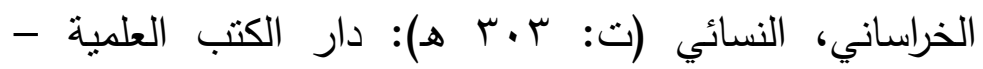

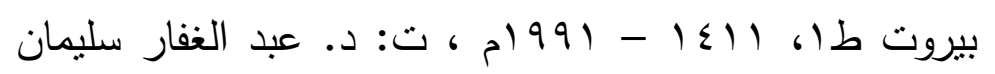
البنداري ، سيد كسروي حسن. 


\section{الصدر أو المرجع}

SV

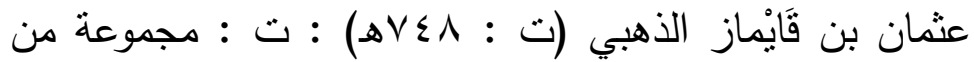

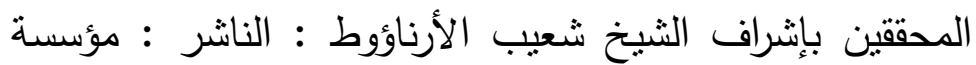

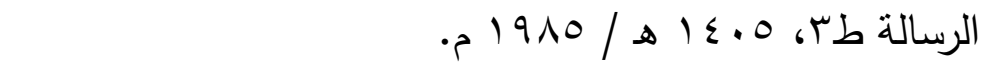

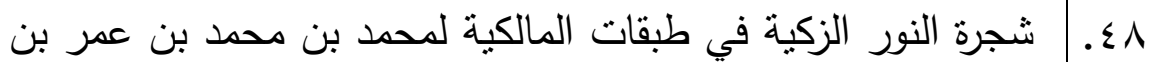
علي ابن سالم مخلوف (ت: • بس أه) علق عليه: عبد المجيد

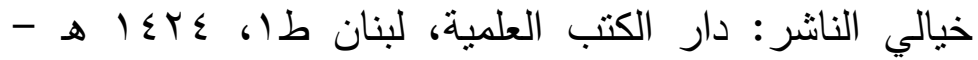
9ء.

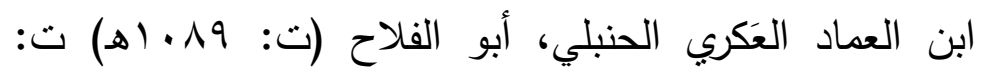

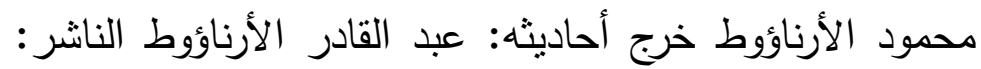

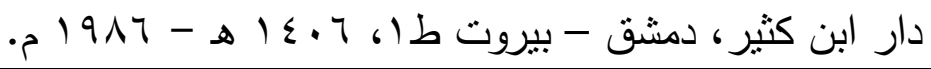

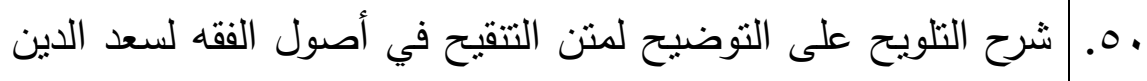

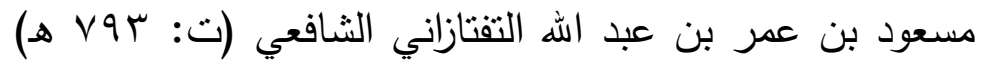

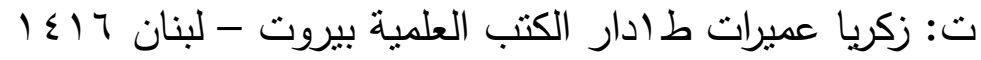

-

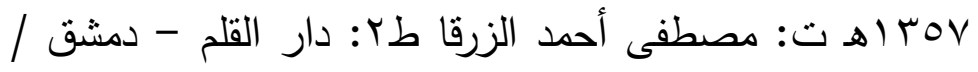

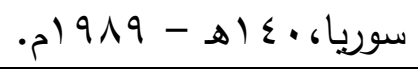

ror. شرح الكوكب المنير لتقي الدين أبو البقاء محمد بن أحمد بن عبد العزيز بن علي الفتوحي المعروف بابن النجار الحنبلي ت 9VT

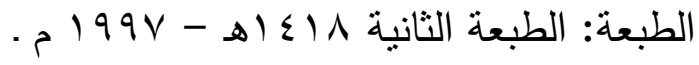




\section{المصدر أو المرجع}

rه. شرح تتقيح الفصول لأبي العباس شهاب الدين أحمد بن إدريس بن

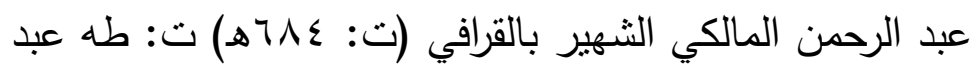
الرؤوف سعد الناشر: شركة الطباعة الفنية المتحدة طاه

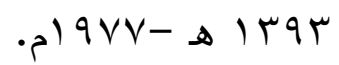

ـه. شرح زاد المستقنع لمحمد بن محمد المختار الثنقيطي مصدر الكتاب: دروس صوتية قام بتفريغها موقع الثبكة الإسلامية.

0. شرح مختصر الروضة لسليمان بن عبد القوي بن الكريم الطوفي

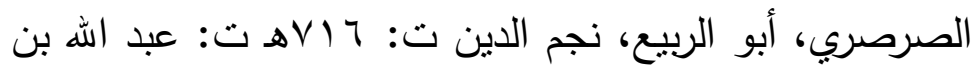

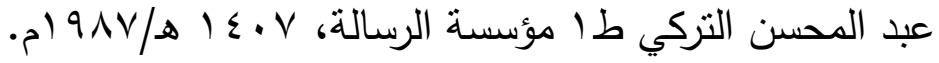
هـ الثرط الجزائي وأثزه في العقود المعاصرة د/ محمد اليمني رسالة

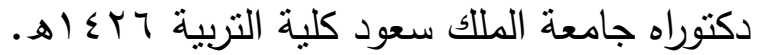

ov الثرط عند الأصوليين د/ الداية، رسالة ماجستير بالجامعة الأردنية كلية الدراسات العليا. 101. الثروط الجعلية في النكاح د/ خالد صالح، بدون. هو. صحيح ابن حبان بترتيب ابن بلبان لمحمد بن حبان بن أحمد بن

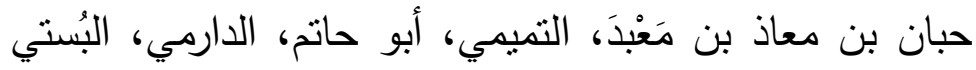

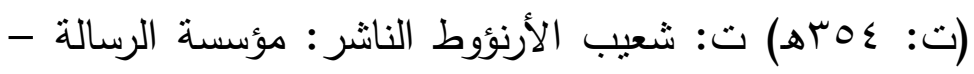

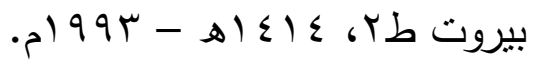

• 7. الجامع المسند الصحيح المختصر من أمور رسول الله صلى الله عليه وسلم وسننه وأيامه = صحيح البخاري لمحمد بن إسماعيل أبو عبداله البخاري الجعفي المحقق: محمد زهير بن ناصر الناصر طا: دار طوق النجاة (مصورة عن السلطانية بإضافة ترقيم

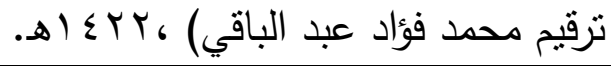




\section{المدر أو المرجع}

آـ. المسند الصحيح المختصر بنقل العدل عن العدل إلى رسول الله صلى الله عليه وسلم لأبي الحسين مسلم بن الحجاج القثبري النيسابوري ت: آجب هـ ت: مجموعة من المحققين الناشر: دار الجيل - بيروت ط: مصورة من الطبعة التركية المطبوعة في

استانبول سنة ع سبا هـ.

r7. الضوء اللامع لأهل القرن التاسع لشمس الدين أبو الخير محمد بن عبد الرحمن السخاوي (ت: r.9.9ه) الناشر: منشورات دار

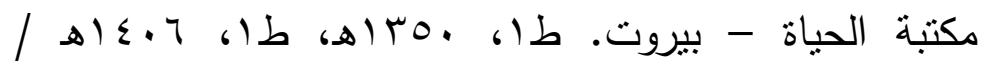

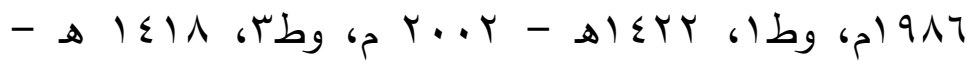

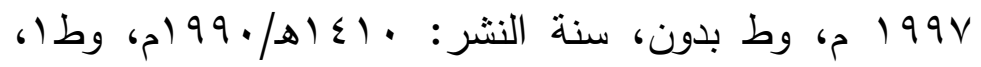

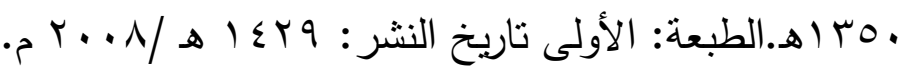
rا7. طبقات الحضيكي لمحمد بن أحمد الحضيكي (ت: 11199 هـ / IVVO § ا. الطبقات السنية في تراجم الحنفية، ت: تقي الدين بن عبد القادر التميمي الداري الغزي (المتوفى: · 1 . 1 هـ) و: د. عبد الفتاح محمد الحلو ، الناشر : دار الرفاعي. 10. الطبقات الكبرى لأبي عبد الله محمد بن سعد بن منيع الهاشمي لرئ بالولاء، البصري، البغدادي المعروف بابن سعد (المتوفى: • 77. عقد الإجارة المنتهي بالتمليك د/ الثثري، ط دار الحبيب بالرياض $\cdot$. 


\section{الصدر أو المرجع}

TV العناية شرح الهداية، المؤلف: محمد بن محمد بن محمود، أكمل الدين أبو عبد الله ابن الثيخ شمس الدين ابن الثيخ جمال الدين

$$
\text { الرومي البابرتي (ت: ؟Aها) الناشر : دار الفكر • }
$$

14. غمز عيون البصائر في شرح الأشباه والنظائر المؤلف: أحمد بن محمد مكي، أبو العباس، شهاب الدين الحسيني الحموي الحنفي (المتوفى: 91 ـ اهـ) الناشر: دار الكتب العلمية الطبعة: الأولى،

. $19100-81 \leqslant 0$

79. الفتاوى الإسلامية من دار الإفتاء المصرية، ط وزارة الأوقاف

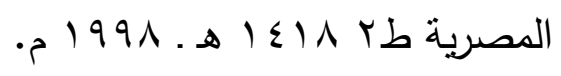

• . . . . Vتاوى الثبكة الإسلامية، المؤلف: لجنة الفتوى بالثبكة الإسلامية. 1V. الفتاوى الثرعية في المسائل الاقتصادية بيت التمويل الكويتي، بدون. فr الع العلي المالك في الفتوى على مذهب الإمام مالك لمحمد بن أحمد بن محمد عليش، أبو عبد الله المالكي (ت: 99 (اهـ)

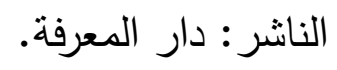

rV. فتح القدير لكمال الدين محمد بن عبد الواحد السيواسي المعروف بابن

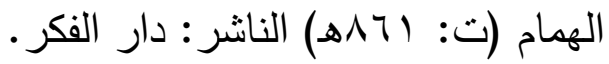

ع V. فتح المعين بشرح قرة العين بمهمات الدين (هو شرح للمؤلف على كتابه هو المسمى قرة العين بمهمات الدين) لزين الدين أحمد بن عبد العزيز بن زين الدين بن علي بن أحمد المعبري المليباري الهندي (ت: 9Av هـ) الناشر : دار بن حزم ط ا، بدون. 


\section{المدر أو المرجع}

هV. الفروق أو أنوار البروق في أنواء الفروق (مع الهوامش): لأبي العباس شهاب الدين أحمد بن إدريس بن عبد الرحمن المالكي الثهير بالقرافي (ت: ع^^ هـ) ت: خليل المنصور الناشر: دار الكتب

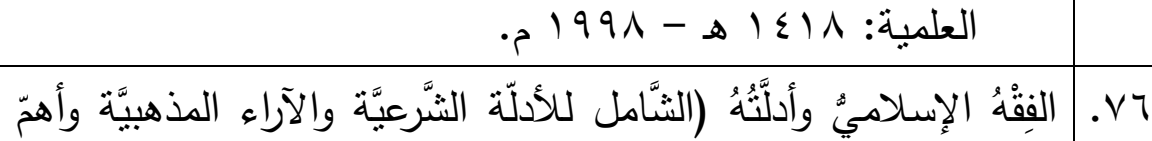
النَّظريَّات الفقهيَّة وتحقيق الأحاديث النَّبَّيَّة وتخريجها) لدورَهْبَة ابن مصطفى الزَّحَيْلِيّ، الناشر : دار الفكر - سوريَّة - دمشق. VV المطلق، ود. محمَّد بن إبراهيم الموسَى الناشر: مَدَارُ الوَطن

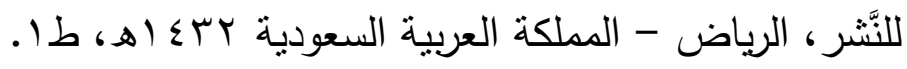
^^. الفقه على المذاهب الأربعة لعبد الرحمن بن محمد عوض الجزيري (ت: • جس (هـ)، دار الكتب العلمية، بيروت - لبنان طب،

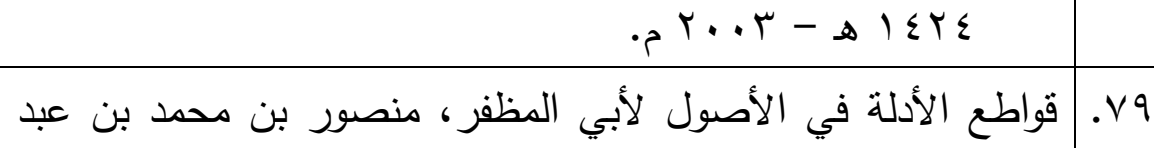
الجبار ابن أحمد المروزي السمعاني التميمي الحنفي ثم الثافعي

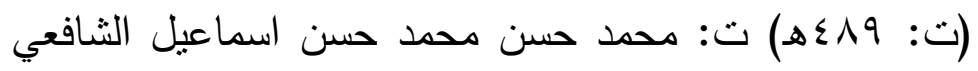

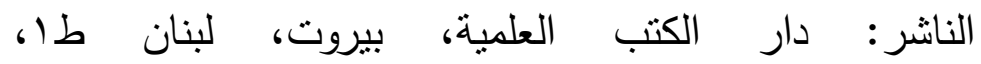

. $9999 / 81 \leq 11$

•.

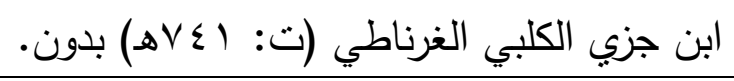

1اء. الكافي شرح البزودي للحسين بن علي بن حجاج بن علي، حسام الدين السِّنْنَاقي (ت: 


\section{المصدر أو المرجع}

1. Y كتاب التعريفات لعلي بن محمد بن علي الزين الثريف الجرجاني (ت: 17 هـ ) ت: ضبطه وصححه جماعة من العلماء بإشراف الناشر : دار الكتب العلمية بيروت - طا س • ع اهـ -rمی ام. rی) كتاب العين لأبي عبد الرحمن الخليل بن أحمد بن عمرو بن تميم

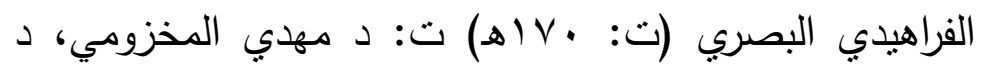
إبراهيم السامرائي الناشر : دار ومكتبة الهلال. §^. كثناف القناع لمنصور بن يونس بن صلاح الدين بن حسن بن إدريس البهوتى الحنبلى (ت: 01 . إه) ط دار الكتب العلمية

1. كثف الأسرار شرح أصول البزدوي: عبد العزيز بن أحمد بن محمد،

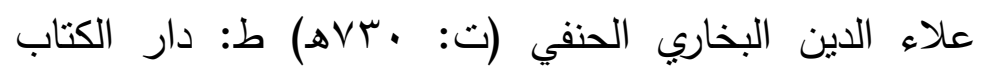

$$
\text { الإسلامي. }
$$

جي. اللباب في شرح الكتاب لعبد الغني بن طالب بن حمادة بن إبراهيم

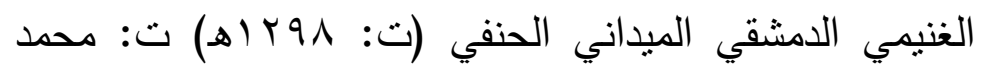

محيي الدين عبد الحميد الناشر : المكتبة العلمية، بيروت.

AV

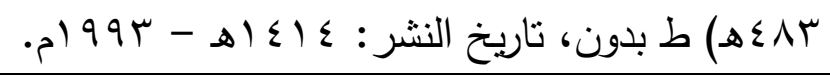

11. مجلة مجمع الفقه الإسلامي التابع لمنظمة المؤتمر الإسلامي بجدة، تصدر عن منظمة المؤتمر الإسلامي بجدة.

19. مجمع الأنهر في شرح ملتقى الأبحر لعبد الرحمن بن محمد بن لإنيان

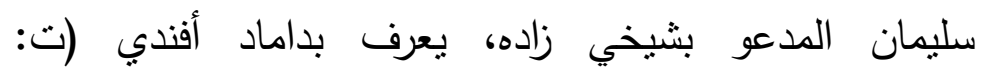

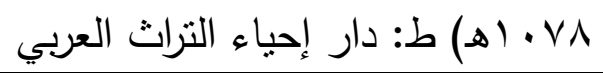




\section{المصدر أو المرجع}

• 9.

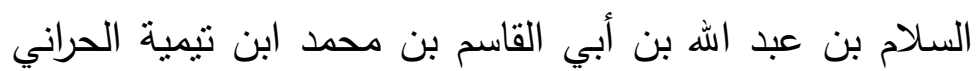
الحنبلي الدمشقي (ت: VYA هـ) ت: أنور الباز - عامر الجزار

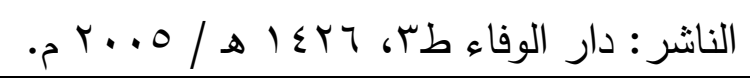

19. المجموع شرح المهذب (مع تكملة السبكي والمطيعي) لأبي زكريا

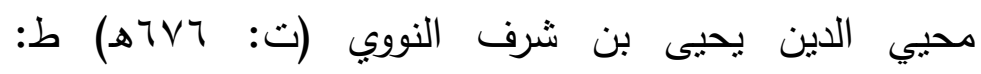

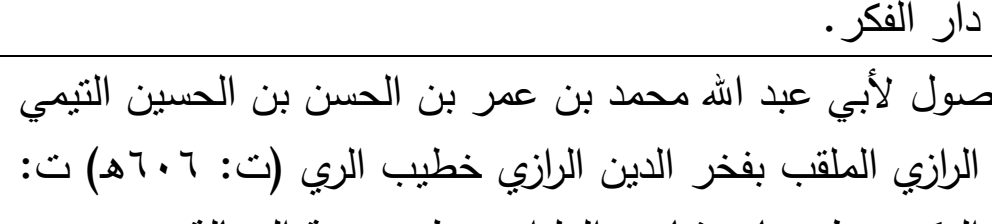
الدكتور طه جابر فياض العلواني: ط مؤسسة الرسالة.

ب9. المحكم والمحيط الأعظم لأبي الحسن علي بن إسماعيل بن سيده

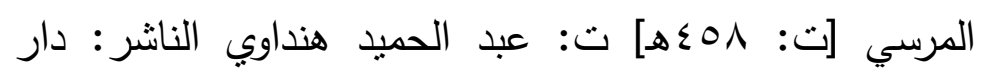

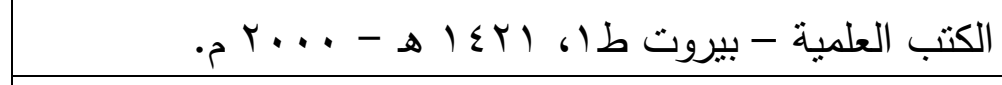

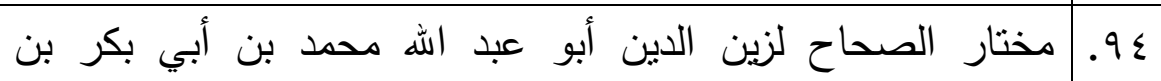

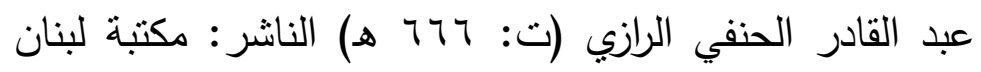

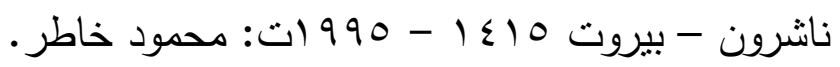
90. المدخل إلى مذهب الإمام أحمد بن حنبل لعبد القادر بن أحمد بن

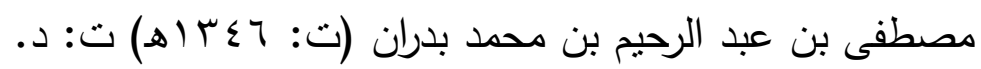

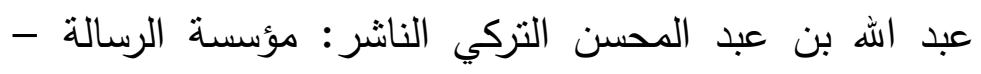

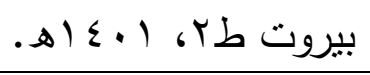

79. مرآة الجنان وعبرة اليقظان في معرفة ما يعتبر من حوادث الزمان

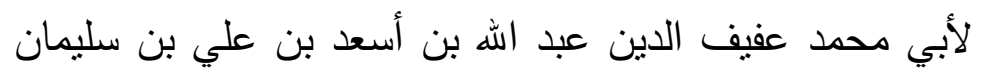

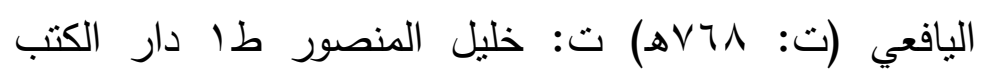

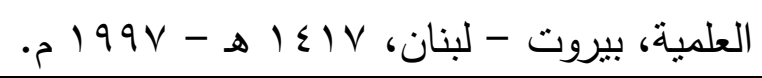




\section{المصدر أو المرجع}

9V. الوافي بالوفيات / / / P صلاح الدين خليل بن أيبك بن عبد الله الصفدي (ت: \& عالهـ) ت: أحمد الأرناؤوط وتركي مصطفى ط

$$
\text { دار إحياء التراث - بيروت . بـ اهـ- . . . بم. }
$$

91. مسند الإمام أحمد بن حنبل لأبي عبد الله أحمد بن محمد بن حنبل بن إهن

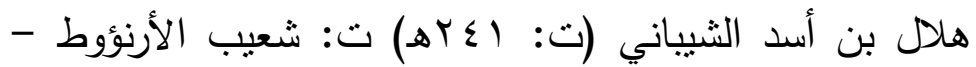
عادل مرشد، وآخرون إثراف: د عبد الله بن عبد المحسن

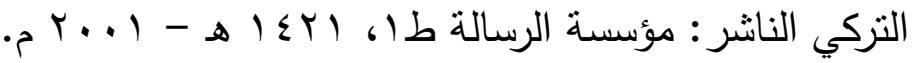
99.

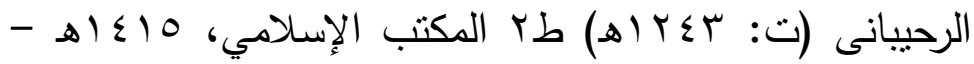

99 أم. 99

. . . المعاملات المالية المعاصرة في الفقه الإسلامي، د محمد عثمان

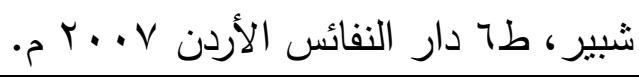

1 ( 1 معجم المصطلحات المالية والاقتصادية في لغة الفقهاء لنزيه حماد،

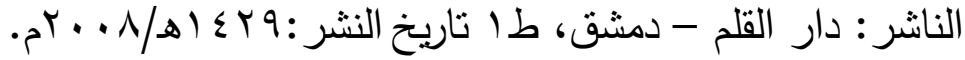
r • ا معجم المؤلفين لعمر رضا كحالة الناشر : مكتبة المثتى - بيروت، دار إحياء التراث العربي بيروت.

r. 1 معجم لغة الفقهاء لمحمد رواس قلعجي - حامد صادق قنيبي، الناشر : دار النفائس للطباعة والنشر والتوزيع طب، 1 . ؛ 1 هـ -

$$
\cdot{ }^{\circ} 1911
$$

ـ ـ ا المغني لابن قدامة ط دار الفكر العربي بيروت ـ لبنان 0. ـ ا هـ. o. 1 منح الجليل شرح مختصر خليل لمحمد بن أحمد بن محمد عليش، المالكي (ت: 99 و اهـ) الناشر: دار الفكر - بيروت الطبعة:

$$
\text { بدون طبعة. }
$$




\section{الثرط الجعلي دراسة أصولية وأثره في الفروع الفقهية في باب الإجارة}

\section{المصدر أو المرجع}

7. 1 المنخول من تعليقات الأصول لأبي حامد محمد بن محمد الغزالي الطوسي (ت: 0.0هـ) ت: الدكتور محمد حسن هيتو، طسدار الفكر المعاصر - بيروت، دار الفكر دمثق - سورية 991 م. م.

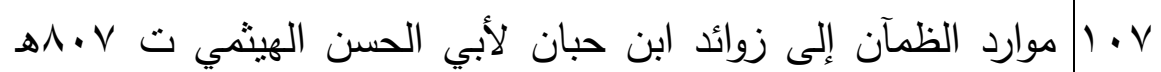

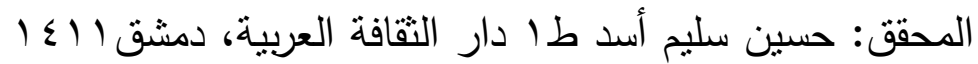

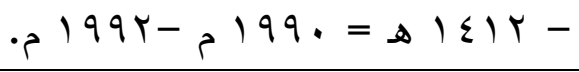

^• 1 الموافقات لإبراهيم بن موسى بن محمد اللخمي الغرناطي الثهير

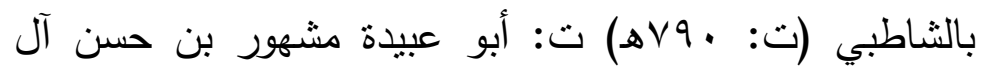

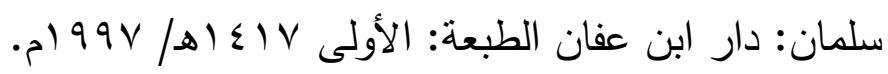
9 1 الموسوعة العربية الميسرة مجموعة باحثين باشراف د حسين ناصر طبعة المكتبة العصرية صيدا بيروت ط س، 9 ه . . م. • 11 موسوعة الفقه الإسلامي لمحد بن إبراهيم بن عبد الله التويجري

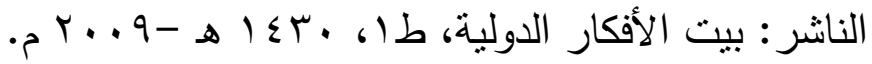
111 الموسوعة الفقهية الكويتية، ط وزارة الأوقاف والثئون الإسلامية دار

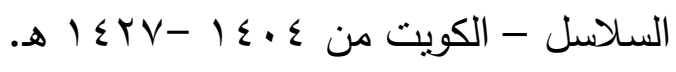
r I ا موقع (الإسلام، سؤال وجواب) إثراف/ الثيخ محمد صالح المنجد.

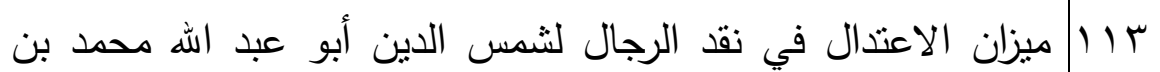

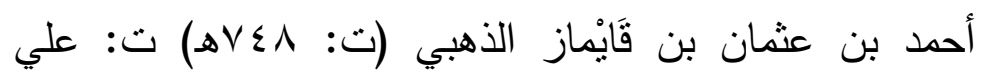
محمد البجاوي الناشر : دار المعرفة للطباعة والنشر، بيروت -

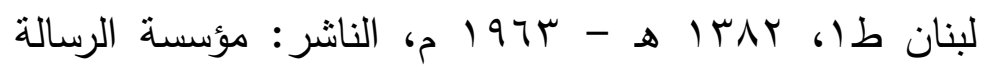

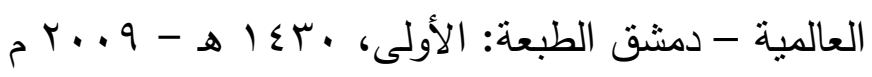


الثرط الجعلي دراسة أصولية وأثره في الفروع الفقهية في باب الإجارة

\section{المدر أو المرجع}

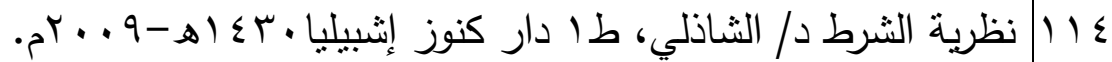
110 - 1941

11 11 نظرية العقد = العقود لتقي الدين أبو العباس أحمد بن عبد الحليم بن

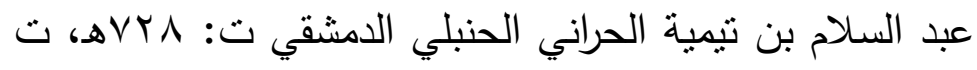
محمد حامد الفقي -محمد ناصر الدين الألباني ط امطبعة

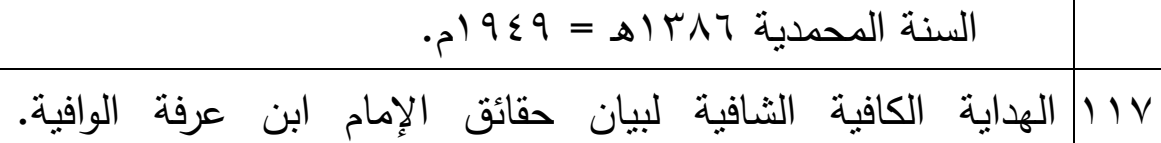
(شرح حدود ابن عرفة للرصاع): محمد بن قاسم الأنصاري،

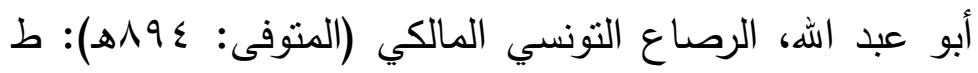
المكتبة العلمية.

11 1ا وفيات الأعيان وأنباء أبناء الزمان لأبي العباس شمس الدين أحمد بن

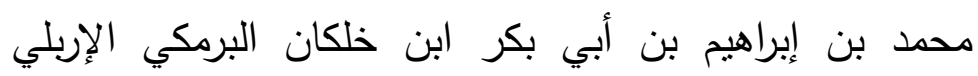
(ت: 111 آهـ) ت: إحسان عباس الناشر : دار صادر - بيروت. 


\section{فهرس الموضوعات}

\begin{tabular}{|c|c|}
\hline |لصفمة & الموضوع \\
\hline rVq & ملخص البحث \\
\hline r^r & 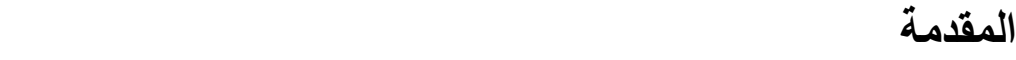 \\
\hline rq. & المبحث الأول: تعريف (الشرط ـ الجعل ـ الإجارة) واختلاف العلماء فيها. \\
\hline rq. & المطلب الأول: تعريف الشرط لغة واصطلاحا عند الحنفية والجمهور \\
\hline rq. & المسألة الأولى: تعريف الثرط لغة \\
\hline (9) & المسألة الثانية: تعريف الثرط اصطلاحا عند الحنفية \\
\hline rat & المسألة الثالثة: تعريف الشرط اصطلاحا عند الجمهور \\
\hline Y9V & المطلب الثاني: تعريف الجعل لغة واصطلاحا \\
\hline Y9V & المسألة الأولى: تعريف الجَعل لغة \\
\hline rqA & المسألة الثانية: تعريف الجَعل اصطلاحا \\
\hline r.. & المسألة الثالثة: تعريف الثرط الجعلي اصطلاحا \\
\hline r. & المطلب الثالث: أدوات الثرط واختلاف العلماء فيها \\
\hline r. & المسألة الأولى: أدوات الشرط \\
\hline r. & المسألة الثانية: أقسام أدوات الشرط \\
\hline r. o & المسأنة الثالثة: الخلاف الوارد في أدوات الشرط \\
\hline$r \cdot v$ & المطلب الرابع: تعريف الإجارة لغة واصطلاحا \\
\hline$r \cdot v$ & المسألة الأولى: تعريف الإجارة لغة \\
\hline$r \cdot \Lambda$ & المسألة الثانية: تعريف الإجارة اصطلاحا \\
\hline ץ & المطلب الخامس: مشروعية الشرط الجعلي \\
\hline מצr & المبحث الثاني: أقسام الشرط عند الحنفية والجمهور \\
\hline
\end{tabular}


الشرط الجعلي دراسة أصولية وأثره في الفروع الفقهية في باب الإجارة

\begin{tabular}{|c|c|}
\hline |الصفحة & 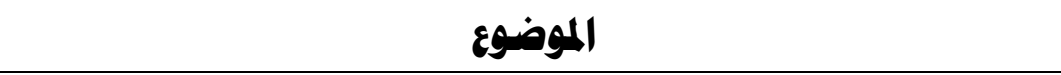 \\
\hline TrT & المطلب الأول: أقسام الشرط عند الحنفية \\
\hline TrV & المطلب الثاني: أقسام الثرط عند الجمهور \\
\hline rrA & الجمهور الثالث أنواع وأقسام الثروط الجعلية عند كلا من الحنفية \\
\hline rrA & المسألة الأولى: أنواع الثروط الجعلية \\
\hline וTr & المسألة الثانية: أقسام الشروط الجعلية من حيث اعتبارها شرعًا \\
\hline זس" & المسألة الثالثة: أقسام الشروط الجعلية باعتبار أثرها على التصرفات \\
\hline זמז & الفرع الأول: الثرط الصحيح \\
\hline צT & الفرع الثاني: الشرط الباطل \\
\hline סחץ & الفرع الثالث: الشرط الفاسد \\
\hline גזr & ولمبتمن خمسة الثالث: أمثلة تطبيقية معاصرة للشروط الجعلية على باب الإجارة. \\
\hline גזr & المطلب الأول: الإيجار المنتهي بالتمليك \\
\hline$r \leq \varepsilon$ & المطلب الثاني: شرط دفع مقدم للإيجار \\
\hline$r \leqslant V$ & المطلب الثالث: الشرط الجزائي في عقود الإيجار \\
\hline ror & المطلب الرابع: الإيجار المؤيد المعروف بالإيجار القايم \\
\hline roo & المطلب الخامس: حكم اشتراط صيانة العين المؤجرة \\
\hline . & 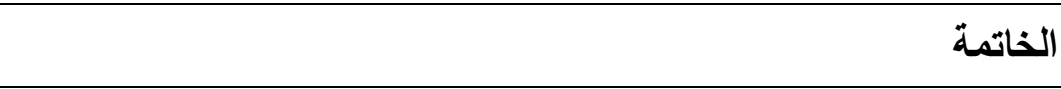 \\
\hline rדז & فهرس المراجع \\
\hline rvq & فهرس الموضوعات \\
\hline
\end{tabular}

